Renata Hydee Hasue

\title{
ORIGEM DA INERVAÇÃO DOPAMINÉRGICA DA DIVISÃO CENTRAL DA AMÍGDALA EXPANDIDA E DA CONCHA DO NÚCLEO ACUMBENS NO RATO
}


Renata Hydee Hasue

\title{
ORIGEM DA INERVAÇÃO DOPAMINÉRGICA DA DIVISÃO CENTRAL DA AMÍGDALA EXPANDIDA E DA CONCHA DO NÚCLEO ACUMBENS NO RATO
}

\author{
Dissertação apresentada ao Instituto \\ de Ciências Biomédicas da USP como parte \\ dos requisitos para obtenção do título de \\ Mestre em Ciências \\ Área de Concentração: Fisiologia Humana \\ Orientadora: Dra. Sara Joyce Shammah-Lagnado
}




\section{AGRADECIMENTOS}

À minha professora do curso de Fisioterapia da USP, ODETE DE FÁTIMA SALLAS DURIGON, por ter despertado em mim, logo no segundo ano da graduação, o gosto pela Neurofisiologia e pela ciência, e por ter me estimulado a seguir a carreira acadêmica;

À minha orientadora, SARA JOYCE SHAMMAH-LAGNADO, por me fornecer o maior exemplo vivo de dedicação e amor àciência;

À ANA MARIA PERAÇOLI CAMPOS, pela colaboração, dedicação e companheirismo que vão além do excelente apoio técnico;

Às COMPANHEIRAS DO LABORATÓRIO DE NEUROANATOMIA, em especial à ADRIANA CELESTINO SANTIAGO, grande amiga, que me ajudou desde os meus primeiros passos "neuroanatômicos" até hoje;

À mais que amiga LUCIANE VALÉRIA SITA, cuja paixão pela evolução do conhecimento e senso crítico extremo, desde a graduação despertam minha admiração e me fortalecem;

Ao Prof. Dr. NEWTON SABINO CANTERAS, por ajudar a aguçar meu espírito científico;

Ao Srs. ROBERTO VIEIRA e ERNESTO RUAS MARQUES, pela manutenção dos equipamentos e dos níveis séricos de cafeína do laboratório, imprescindíveis para a realização deste trabalho;

Ao Sr. ITAMAR KLEMPS, técnico de informática;

Aos SECRETÁRIOS do Departamento de Fisiologia e Biofísica;

Às BIBLIOTECÁRIAS do ICB;

À FAPESP pelo apoio financeiro (processo número 98/05360-3);

Aos meus pais, IRACEMA MORETTI HASUE e MATUSUFUMI HASUE, meu irmão, FABIO MATSU HASUE, e meu noivo RUBENS ANTONIO VILIBOR, pelo amor e apoio que não cabem em uma lista, aos quais dedico este trabalho. 


\section{RESUMO}

A divisão central da amígdala expandida é um contínuo rostrocauldal formado pelos núcleos central da amígdala e intersticial lateral da estria terminal, e os corredores celulares que os interligam. Estes corredores celulares são representados dorsalmente pela porção lateral do núcleo intersticial supracapsular da estria terminal, e ventralmente pela divisão central da região sublenticular e pela porção medial do núcleo intersticial do ramo posterior da comissura anterior. Esta macroestrutura, assim como a concha do núcleo acumbens, recebe densa inervação dopaminérgica, crucialmente implicada em processos motivacionais, dentre eles, a adição a drogas psicoativas. A origem desta inervação dopaminérgica foi estudada através da técnica de dupla marcação celular, associando reação imunofluorescente para tirosina hidroxilase $(\mathrm{TH})$ àinjeção iontoforética de traçador retrógrado Fluoro Gold (FG) nos principais componentes da amígdala expandida central ou nos subterritórios da concha do acumbens. A contribuição dos grupamentos dopaminérgicos A8 a A14 para a inervação destas duas estruturas foi quantificada e descrita em detalhes. As células positivas para TH que se projetam para os núcleos central da amígdala e intersticial lateral da estria terminal são semelhantes em proporção e localização topográfica, sendo que metade está no grupamento dopaminérgico A10dc (localizados no núcleo dorsal da rafe e substância cinzenta periaquedutal) e metade nos grupamentos A8/A10 do mesencéfalo ventral. Usandose um anticorpo específico para dopamina, constatamos que parte da projeção do grupamento A10dc para o núcleo central da amígdala é de fato dopaminérgica. A inervação dopaminérgica do corredor ventral da amígdala expandida e da concha do acumbens é oriunda predominantemente dos grupamentos A8/A10, sendo que as 
projeções dopaminérgicas do A10 para a concha do acumbens possuem uma organização topográfica mediolateral direta e dorsoventral invertida. Os grupamentos diencefálicos (A11, A12, A13 e A14) praticamente não contribuem para a inervação dopaminérgica da divisão central da amígdala expandida da concha e do acumbens. 


\section{ABSTRACT}

The central division of the extended amygdala is a basal forebrain continuum that includes the central amygdaloid nucleus, the lateral bed nucleus of the stria terminalis and the cell columns that bridge the gap between these two structures. The ventral cell column is represented by the central division of the sublenticular region and the interstitial nucleus of the posterior limb of the anterior commissure, and the dorsal cell column corresponds to the lateral supracapsular bed nucleus of the stria terminalis. The central division of the extended amygdala, and the shell of the nucleus accumbens, are dopamine rich territories, functionally implicated in motivated behaviors, reward and drug addiction. The origin of the dopaminergic innervation of the central extended amygdala and nucleus accumbens shell was studied by combining immunofluorescence to tyrosine hydroxylase $(\mathrm{TH})$ and FluoroGold (FG), used as retrograde tracer. Following FG injections into the main components of central extended amygdala and nucleus accumbens shell, retrogradely (FG-immunoreactive) and double-labeled (FG- and TH-immunoreactive) cells located in A8 to A14 dopaminergic groups were quantified. Our results show that dopaminergic fibers to the central amygdaloid nucleus and lateral bed nucleus of the stria terminalis derive in equal proportion from neurons in ventral tegmental area (A10) and in dorsal raphe nucleus/periaqueductal gray (A10dc), whereas dopaminergic inputs to sublenticular extended amygdala, interstitial nucleus of the posterior limb of the anterior commissure and accumbens shell arise mainly from A10 neurons in ventral tegmental area. Using a dopamine antibody, we confirmed that A10dc projections to central amygdaloid nucleus are in part dopaminergic. 
Futhermore, the present data indicate that the diencephalic dopaminergic groups do not project to central division of the extended amygdala and accumbens shell. 


\section{SUMÁRIO}

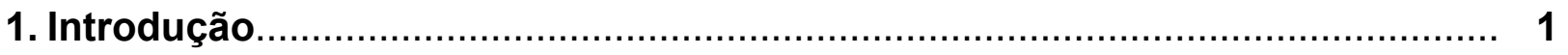

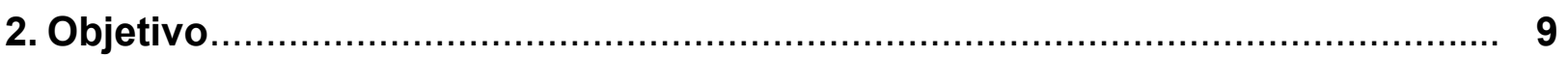

3. Materiais e Métodos........................................................................ 10

3.1. Experimentos para visualização de Fluoro-Gold e tirosina hidroxilase................... 11

3.2. Experimentos para visualização da dopamina................................................ 14

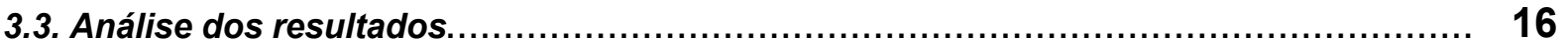

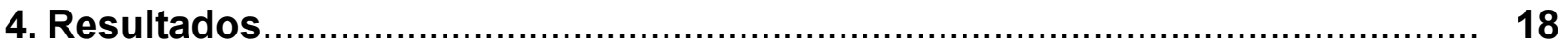

4.1. Casos com injeção no núcleo central da amígdala......................................... 20

4.2. Casos com injeção no núcleo intersticial lateral da estria terminal...................... 27

4.3. Casos com injeção na amígdala expandida sublenticular................................ 34

4.4. Casos com injeção no núcleo intersticial do ramo posterior da comissura anterior..... 42

4.5. Casos com injeção na concha do núcleo acumbens...................................... 49

4.6. Experimentos para a detecção da Dopamina.................................................. 63

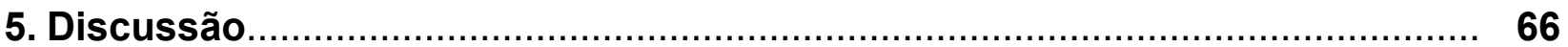

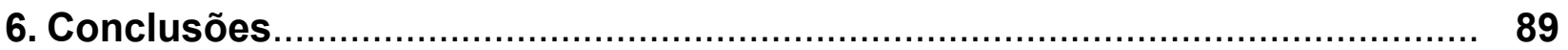

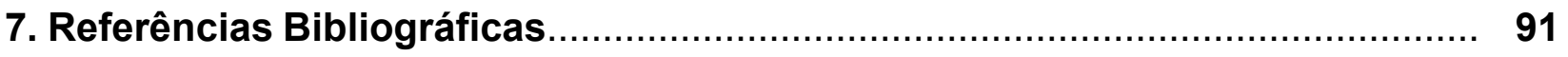




\section{LISTA DE ABREVIATURAS}

AADC- L-aminoácido aromático descarboxilase

A8-A16- grupamentos dopaminérgico de 8 a 16

ac- comissura anterior

Acb- núcleo acumbens

AcbSh- concha do núcleo acumbens

acp- ramo posterior da comissura anterior

Arq- núcleo arqueado do hipotálamo

La/BL- complexo amigdalóide basolateral

BST- núcleo intersticial da estria terminal

BSTI- núcleo intersticial lateral da estria terminal

BSTS- porção supracapsular do núcleo intersticial da estria terminal

CPu- núcleos caudado e putâmem

CeA- núcleo central da amígdala

CeMeA- complexo centromedial da amígdala

CLi- núcleo linear caudal da rafe

DA- dopamina

$\mathrm{DBH}$ - dopamina $\beta$-hidroxilase

DR- núcleo dorsal da rafe

EAc- amígdala expandida, divisão central

FG- Fluoro-Gold

fr- fascículo retroflexo

fx- fórnix

GP-globo pálido

ic- cápsula interna

IF- núcleo interfascicular

IP- núcleo interpeduncular

IPAC- núcleo intersticial do ramo posterior da comissura anterior

L-DOPA- L-3,4-dihidroxifenilalanina

Im- lemnisco medial

LS- área septal lateral

Iv- ventrículo lateral 
mt- trato mamilo-talâmico

ot- trato óptico

PAG- substância cinzenta periaquedutal

PB- área parabraquial

PBP- núcleo parabraquial pigmentoso

pc- pedúnculo cerebral

PN- núcleo paranigral

PVH- núcleo periventricular do hipotálamo

R- núcleo rubro

RIMLF- núcleo intersticial rostral do fascículo longitudinal medial

RLi- núcleo linear rostral da rafe

RNAm- ácido ribonucleico, mensageiro

RR- campo retrorrubral

RRs- porção supralemniscal do campo retrorrubral

SCC- substância cinzenta central

SCPV- substância cinzenta periventricular

SLEA- amígdala expandida sublenticular

SLEAc- amígdala expandida sublenticular, porção central

SN- substância negra

SNcd- substância negra, pars compacta, porção dorsal

SNcv- substância negra, pars compacta, porção ventral

SNI- substância negra, pars lateralis

SNr- substância negra, pars reticulata

st- estria terminal

SuM- região supramamilar

$\mathrm{TH}$ - tirosina hidroxilase

VTA- área tegmental ventral

VTAr- área tegmental ventral, parte rostral

xspc- decussação do pedúnculo cerebelar superior

ZIm- zona incerta, parte medial 


\section{INTRODUÇÃO}

\section{Amígdala}

A amígdala é uma estrutura ovoidal do prosencéfalo basal que está inserida no lobo temporal, localizada ventralmente ao uncus do giro parahipocampal, e anteriormente ao hipocampo e ao corno temporal do ventrículo lateral no homem. Genericamente, a amígdala está envolvida em funções cognitivas, como memória e aprendizado (Brown et al., 1996) e comportamentais, onde participa do processamento emocional e motivacional, do controle autonômico e neuroendócrino (Price et al., 1987; Heimer et al., 1993; Heimer, 1994; Alheid et al., 1995). Um dos primeiros indícios do envolvimento da amígdala na modulação do comportamento emocional foi obtido com a ablação bilateral do corpo amigdalóide no macaco (ver Price et al., 1987). Alterações como perda da agressividade e da conotação de estímulo nocivo, comportamento sexual inapropriado e hiperoralidade foram vistas nestes animais lesados, e constituíram a denominada síndrome de Klüver-Bucy. Diversas técnicas experimentais têm indicado ainda a participação fundamental da amígdala na aquisição, consolidação e retenção ou expressão do medo condicionado (Davis et al., 1994). Porém, a amígdala está longe de representar uma estrutura homogênea do ponto de vista neuroquímico, anatômico e funcional. Entender a amígdala como uma estrutura anatomicamente heterogênea tem contribuído para o estabelecimento de subsistemas relacionados a circuitos neuronais distintos (ver revisão de Alheid et al., 1995).

Três grandes complexos nucleares podem ser identificados na amígdala: a amígdala basolateral, estreitamente relacionada com o córtex cerebral, a amígdala 
olfatória, relacionada com o bulbo olfatório e o córtex olfatório, e a amígdala centromedial, que constitui a principal via de saída amigdaliana para o hipotálamo e estruturas somáticas e autonômicas do tronco cerebral (Alheid et al., 1995). Os núcleos central e medial da amígdala, em especial, são intimamente relacionados com um contínuo de estruturas que se estendem rostralmente através de um corredor dorsal e outro ventral, e cuja extremidade rostral é representada pelo núcleo intersticial da estria terminal (de Olmos et al., 1985; de Olmos e Heimer, 1999). Este contínuo de estruturas, que possui a mesma origem embriológica, foi denominado amígdala expandida.

\section{Amígdala expandida}

O corredor celular dorsal que une o complexo centromedial da amígdala ao núcleo intersticial da estria terminal é representado pelo núcleo intersticial supracapsular da estria terminal (de Olmos et al., 1985; Alheid et al., 1998; Shammah-Lagnado et al, 2000), enquanto que o corredor ventral é representado pela região sublenticular (também referida como substância inominada) (de Olmos et al., 1985; Grove, 1988a, 1988b; Heimer, 1997) e pelo núcleo intersticial do ramo posterior da comissura anterior (IPAC) (Alheid et al., 1999; Shammah-Lagnado et al., 1999; ver Fig. 1). Evidências embriológicas, citoarquitetônicas, hodológicas e neuroquímicas diferenciam a amígdala expandida do restante do prosencéfalo basal, bem como dos outros complexos nucleares da amígdala (amígdala basolateral e a amígdala olfatória) (ver Alheid et al., 1995; Heimer et al., 1993; de Olmos e Heimer, 1999). 
A amígdala expandida é dividida em duas partes, uma central e outra medial, cada uma delas composta pelas estruturas relacionadas aos núcleos amigdalóides central e medial, respectivamente (Alheid et al., 1995; de Olmos e Heimer, 1999). A divisão central da amígdala expandida é formada pelo núcleo central da amígdala, núcleo intersticial lateral da estria terminal, parte lateral do núcleo intersticial supracapsular da estria terminal, divisão central da amígdala expandida sublenticular e porção medial do núcleo intersticial do ramo posterior da comissura anterior (Alheid et al., 1999; Shammah-Lagnado et al., 1999, 2000; ver Fig. 2). Evidências hodológicas corroboram a distinção entre as divisões medial e central da amígdala expandida. A divisão medial está relacionada primariamente com eventos neuroendócrinos (Heimer et al., 1997; de Olmos e Heimer, 1999), enquanto que a divisão central da amígdala expandida está relacionada principalmente com o processamento de respostas somatomotoras (Heimer et al., 1993, 1997) e autonômicas (Gelsema et al., 1993). Foi visto ainda um envolvimento da divisão central da amígdala expandida na indução do apetite ao sódio (Zardetto-Smith et al., 1994), e como sítio da ação de drogas anti-depressivas (Morelli et al., 1999).

\section{Divisão central da amígdala expandida e dopamina}

Uma diferença marcante entre as duas divisões da amígdala expandida é que sua divisão central é densamente inervada por neurônios dopaminérgicos, enquanto sua divisão medial recebe muito poucas terminações dopaminérgicas (Freedman e Cassel, 1994). A dopamina pode agir na amígdala expandida através de receptores dopaminérgicos do tipo $D_{1}$ (Caroleo et al., 1998; Epping-Jordan et al., 1998) e $D_{2}$ (Weiner et al., 1991). 


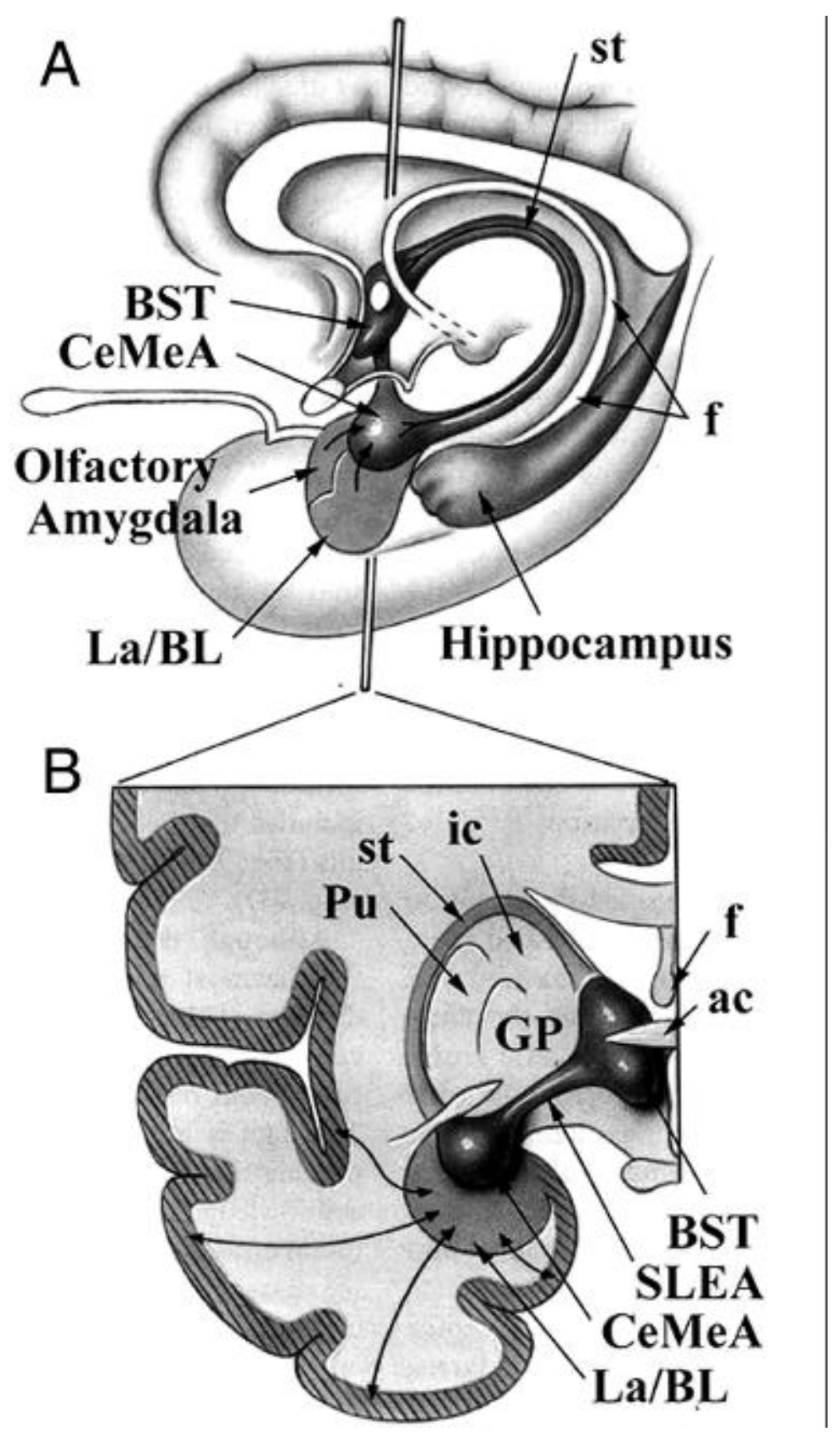

Figura 1: Amígdala e amígdala expandida. (A) Representação esquemática em plano sagital da amígdala olfatória, complexo basolateral e complexo centromedial da amígdala no homem. (B) Visualização de um corte frontal feito em $(A)$, representando os principais componentes da amígdala expandida: núcleo intersticial da estria terminal, amígdala expandida sublenticular e núcleos central e medial da amígdala. (Adaptado de Heimer, L: Human Brain and Spinal Cord, $2^{\text {nd }}$ ed., Springer-Verlag, 1994). Abreviaturas: ac, comissura anterior; BST, núcleo intersticial da estria terminal; $\mathrm{CeMeA}$, complexo centromedial da amígdala; f, fórnix; GP, globo pálido; ic, cápsula interna; La/BL, complexo basolateral da amígdala; Pu, putâmem; SLEA, amígdala expandida sublenticular; st, estria terminal. 


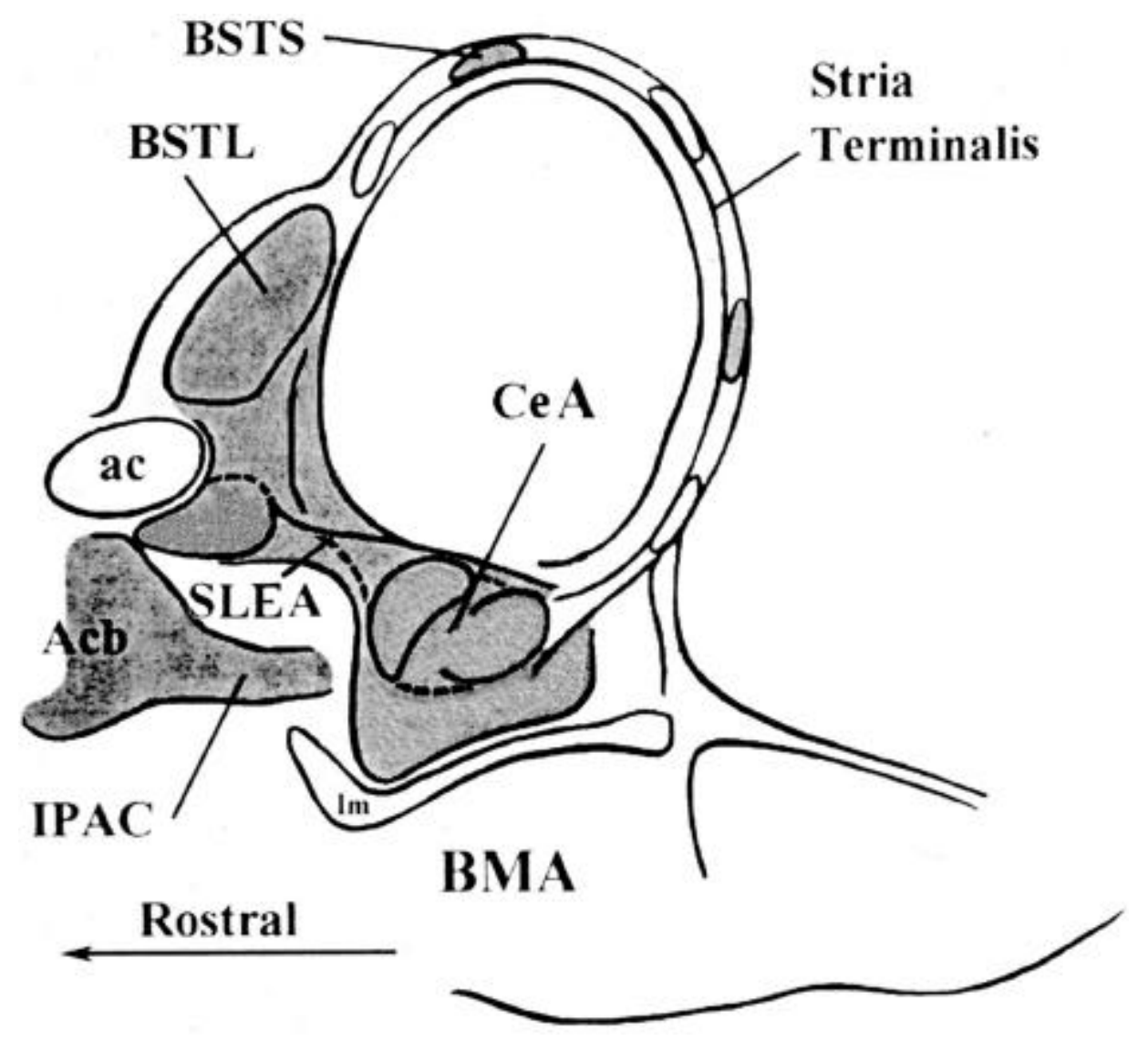

Figura 2: Representação esquemática em plano sagital dos componentes da divisão central da amígdala expandida (em cinza) no homem. Núcleo central da amígdala, amígdala expandida sublenticular, núcleo intersticial do ramo posterior da comissura anterior, núcleo intersticial lateral da estria terminal e porção lateral do núcleo intersticial supracapsular da estria terminal. (Adaptado de Alheid et al.: Amygdala and extended amygdala. In: The Rat Nervous System, Paxinos, G. [editor], $2^{\text {nd }}$ ed., Academic Press, 1995). Para abreviaturas, ver lista. 
A dopamina na divisão central da amígdala expandida parece ter uma participação crucial durante o reforço positivo associado a processos biológicos, incluindo a adição a drogas psicoativas (Koob et al., 1993, 1999). Drogas como a anfetamina induzem o aumento da liberação da dopamina no núcleo central, e também no núcleo basolateral, da amígdala (Young e Rees, 1998). O reforço ao uso da cocaína foi relacionado àativaç ão dos receptores dopaminérgicos do tipo $D_{1}$ presentes na divisão central da amígdala expandida (Epping-Jordan et al., 1998). A ativação pela cocaína dos receptores dopaminérgicos $D_{1}$ do núcleo central da amígdala parece estar ainda associada àproliferação de células $T$ do sistema imunológico (Caroleo et al., 1998). Os receptores $D_{1}$ do núcleo central, e possivelmente do basolateral, da amígdala foram associados à aquisição e expressão do medo condicionado (Guarraci et al., 1999). Alterações nos níveis de dopamina na amígdala expandida central foram observadas em indivíduos esquizofrênicos, o que indica o seu envolvimento em distúrbios neuropsiquiátricos (Heimer et al., 1993, 1997).

\section{Concha do núcleo acumbens e dopamina}

Além da amígdala expandida central, a concha do núcleo acumbens é uma importante estrutura do prosencéfalo basal onde a liberação da dopamina está associada ao mecanismo de reforço a comportamentos naturais, como sexo e ingestão de comida e líquidos (ver revisão de Spanagel e Weiss, 1999) e ao comportamento de busca por drogas psicoativas (Deutch et al., 1993; Heimer et al., 1993, 1997; Koob et al., 1993, 1999; Davis et al., 1994). A liberação de dopamina na concha do núcleo acumbens parece salientar um estímulo relevante, funcionando 
como um sinal para o aprendizado (Di Chiara et al., 1999; Spanagel e Weiss, 1999). Sob tal aspecto, a concha do acumbens se diferencia do cerne do acumbens, cuja modulação dopaminérgica parece estar predominantemente relacionada àatividade motora do sistema estriadopalidal ventral (Heimer et al., 1991; Zahm e Brog, 1992; Brog et al., 1993; Deutch et al., 1993; Lynd-Balta e Haber, 1994; Di Chiara et al., 1999). Assim, o estresse psicológico leva ao aumento dos níveis de dopamina na concha, mas não no cerne do acumbens (Wu et al., 1999). Foi visto que a cocaína aumenta a expressão do RNAm da neurotensina, um neuropeptídeo que modula a transmissão dopaminérgica, na concha, mas não no cerne do núcleo acumbens (Betancur et al., 1997). Diaz et al. (1994) em seu estudo observaram ainda que grande parte dos neurônios da porção ventromedial da concha do acumbens que contém neurotensina possuem também o receptor dopaminérgico $D_{3}$. A concha do acumbens é por si um subterritório de organização complexa, onde grupamentos celulares densamente imunorreativos a anticorpos para diversas substâncias estão entremeados a regiões de fraca imunorreatividade (Zahm e Brog, 1992). Assim, a distribuição das fibras dopaminérgicas possui um padrão heterogêneo (Voorn et al., 1986), sendo mais acentuado na parte caudodorsomedial da concha do núcleo acumbens, denominada pólo septal.

A concha do acumbens parece representar uma área de interface límbicomotora, relacionando-se simultaneamente com o estriado ventral e com a amígdala expandida. Projeções da concha do núcleo acumbens para a amígdala expandida sublenticular e hipotálamo lateral foram descritas com técnicas de rastreamento anterógrado (Heimer et al., 1991). As relações entre a concha do núcleo acumbens e 
a amígdala expandida central parecem ser bidirecionais (Phillipson e Griffiths, 1985; Brog et al., 1993; Alheid et al., 1999; ver porém Zahm et al., 1999).

Origem da inervação dopaminérgica da divisão central da amígdala expandida e da concha do núcleo acumbens

Ungerstedt (1971), através de experimentos baseados em lesões, descreveu uma das primeiras evidências sobre a existência de um sistema dopaminérgico mesolímbico, que se originava do grupamento dopaminérgico A10 de Dahlström e Fuxe (1964). Mais tarde, as projeções mesolímbicas para a amígdala e o acumbens foram estudadas por Fallon e colaboradores (ver revisões de Fallon e Moore, 1978; Björklund e Lindvall, 1984; Oades e Halliday, 1987; Fallon e Loughlin, 1995). Através de técnicas de rastreamento anterógrado e retrógrado, foi visto que grupamentos celulares do mesencéfalo ventral, que contém numerosos neurônios dopaminérgicos identificados com a técnica da histofluorescência pelo ácido glioxílico, se projetam para a amígdala e o acumbens (Fallon e Moore, 1978). Estes grupamentos mesencefálicos ventrais formam o complexo nigral, constituído pelo campo retrorrubral, substância negra e área tegmental ventral, que contém, respectivamente, os grupos dopaminérgicos A8, A9 e A10 de Dahlström e Fuxe (1964). Outros estudos confirmaram as projeções do complexo nigral para a amígdala e núcleo acumbens através de técnicas de rastreamento anterógrado (Beckstead et al., 1979; Oades e Halliday, 1987) e retrógrado (Nauta et al., 1978; Phillipson e Griffiths, 1985; Klitenick et al., 1992; Lynd-Balta e Haber; 1994), mas também não determinaram de forma precisa se estas projeções se originam de fato de neurônios dopaminérgicos. 
A natureza neuroquímica destas projeções foi investigada com o advento das técnicas de dupla marcação celular, associando injeção de traçador retrógrado à detecção da enzima tirosina hidroxilase (TH), que participa da síntese da dopamina (Swanson, 1982; Deutch et al., 1988; Seroogy et al., 1989). Contudo, nos trabalhos de Swanson e de Seroogy et al., as injeções do traçador retrógrado eram pouco restritas, abarcando simultaneamente regiões que também são ricamente inervadas por neurônios dopaminérgicos, e que estão relacionadas a sistemas neurais distintos. Por exemplo, no estudo de Swanson (1982) as injeções obtidas envolvem o núcleo central e também o basolateral da amígdala, além de se espraiarem dorsalmente para o estriado, enquanto que Seroogy et al. (1989) obtiveram injeções que envolvem ao mesmo tempo a concha e o cerne do núcleo acumbens. Além disso, a análise da marcação retrógrada foi feita de maneira pouco detalhada no estudo de Seroogy et al., que considerou a área tegmental ventral como um todo, sem distinguir cada um de seus subnúcleos. Deutch et al. (1988), por sua vez, enfocaram apenas as projeções oriundas do grupamento A8 para distritos da amígdala expandida central e para o núcleo acumbens.

Há ainda relatos na literatura indicando que a inervação dopaminérgica da amígdala e núcleo acumbens se origina também de outros territórios além dos grupamentos mesencefálicos ventrais. Assim, Stratford e Wirtshafter (1990) observaram células imunorreativas ao anticorpo anti-TH (TH-ir) no núcleo dorsal da rafe e na substância cinzenta periaquedutal que se projetam para o núcleo acumbens no rato. Estas células presumivelmente dopaminérgicas (expressam a enzima TH, mas não a enzima dopamina- $\beta$-hidroxilase, responsável pela conversão da dopamina em noradrenalina) correspondem à porção dorsal e caudal do 
grupamento A10 (A10dc; ver Hökfelt et al., 1984). Uma participação dos grupamentos dopaminérgicos A11 (correspondente ao núcleo subparafascicular magnocelular do tálamo) e A13 (correspondente àzona incerta medial) na inervação dopaminérgica da amígdala também foi sugerida (Takada, 1993; Eaton et al., 1994; Cheung et al., 1998). Alguns destes resultados são controversos. Assim, a existência de uma projeção dopaminérgica oriunda do grupo A11 para a amígdala foi descartada por Moriizumi e Leduc-Cross (1992).

De um modo geral, os estudos sobre aferências dopaminérgicas consideraram a amígdala ou o acumbens como um todo, não existindo informações sobre as aferências dopaminérgicas dos diferentes componentes da divisão central da amígdala expandida, ou ainda da concha do acumbens. 


\section{OBJETIVO}

O objetivo deste trabalho é determinar de forma detalhada e comparativa a contribuição de cada grupamento dopaminérgico do diencéfalo e mesencéfalo para a inervação dos principais componentes da amígdala expandida central e da concha do núcleo acumbens. Esta análise será realizada a partir de experimentos de dupla marcação celular com traçador retrógrado Fluoro-Gold, associado à imunofluorescência para $\mathrm{TH}$ ou, em alguns casos, à imunofluorescência com anticorpo específico para dopamina. 


\section{MATERIAIS E MÉTODOS}

Todos os experimentos utilizaram ratas albinas adultas, da cepa Wistar, provenientes do biotério central do ICB-USP. Estes animais foram mantidos com água e comida à vontade e possuíam peso entre $170 \mathrm{~g}$ e $220 \mathrm{~g}$. Todos os procedimentos cirúrgicos foram realizados sob anestesia geral com Equitesin (3,3 $\mathrm{ml} / \mathrm{Kg}$ ) ou hidrato de cloral $(400 \mathrm{mg} / \mathrm{Kg}$ ). Todos os procedimentos envolvendo animais seguiram o protocolo aprovado pelo comitê de ética em experimentação animal e as recomendações sobre uso de animais em pesquisa aprovado pela "Society for Neuroscience".

Depois de anestesiados, os animais foram posicionados em mesa cirúrgica, onde foram realizadas as injeções estereotáxicas unilaterais de traçador retrógrado Fluoro-Gold (FG; Fluorochrome, Inc). Micropipetas de vidro com ponta de diâmetro interno ao redor de $20 \mu \mathrm{m}$ foram preenchidas com o traçador $\mathrm{FG}$ a $2 \%$ em solução salina ( $\mathrm{NaCl}$ 0,9\%). O FG foi ejetado iontoforeticamente passando-se uma corrente elétrica positiva de 2,5 a 3,0 $\mu \mathrm{A}$ (sob a forma de pulsos de sete segundos de duração), por um tempo que variou de cinco a dez minutos. Estes parâmetros de injeção foram estabelecidos de forma a possibilitar um depósito de FG que abarcasse a maior parte do núcleo alvo, sem entretanto, ultrapassar os limites do mesmo. As seguintes estruturas receberam depósito de FG:

a) núcleo central da amígdala, $n=44$;

b) núcleo intersticial lateral da estria terminal, $n=17$;

c) divisão central da amígdala expandida sublenticular, $n=9$;

d) núcleo intersticial do ramo posterior da comissura anterior, $n=2$; 
e) concha do núcleo acumbens, $n=6$.

O FG é um traçador retrógrado fluorescente que não apresenta evidências de degradação em animais com sobrevida de até trinta dias. Longos períodos de sobrevida parecem até intensificar o sinal fluorescente emitido (de Olmos, comunicação pessoal). Muitos estudos com FG utilizaram sobrevidas curtas (3 a 5 dias), inclusive para descrever projeções longas (como exemplo ver Brog et al., 1993). Portanto, o FG parece ser um traçador que pode ser utilizado com grandes variações de tempo de sobrevida ( 3 a 30 dias), uma vez que é rapidamente transportado pelo neurônio e é armazenado no pericário por um longo período, sem ser degradado. Em nossos experimentos a sobrevida variou de 7 a 14 dias, sendo então os animais profundamente anestesiados e perfundidos através de uma cânula intracardíaca conectada a uma bomba peristáltica (Cole Parmer) e destinados a:

\subsection{Experimentos para visualização de Fluoro-Gold e tirosina hidroxilase}

Durante a perfusão, os animais receberam aproximadamente $100 \mathrm{ml}$ de solução salina, àtempe ratura ambiente, seguida por um fluxo $(500 \mathrm{ml} / 25 \mathrm{~min})$ de uma solução de paraformaldeído diluído a 4\% em tampão fosfato de sódio $0,1 \mathrm{M} \mathrm{(pH}$ $7,4)$, a $4^{\circ} \mathrm{C}$. Os cérebros permaneceram em geladeira na própria calota craniana para pós-fixação por um período de quatro horas, após o qual foram dissecados e transferidos para uma solução de sacarose a $20 \%$ em tampão fosfato de sódio 0,1 $\mathrm{M}, \mathrm{pH} 7,4$, a $4^{\circ} \mathrm{C}$, onde permaneceram até o dia seguinte (aproximadamente 12 horas).

Os cérebros foram então submetidos a microtomia de congelação e os cortes distribuídos seriadamente em seis compartimentos (A, B, C, D, E e F). Os 
compartimentos B e D continham cortes em plano frontal de $40 \mu \mathrm{m}$ de espessura de todo o cérebro. Os compartimentos A e C continham cortes em plano frontal de 20 $\mu \mathrm{m}$ de espessura da região que contém os grupamentos dopaminérgicos A8 a A14 (compreendida entre 2,0 $\mathrm{mm}$ e 9,0 $\mathrm{mm}$ caudal ao bregma), e de $40 \mu \mathrm{m}$ de espessura do restante do cérebro. Os compartimentos E e F continham apenas cortes em plano frontal de $20 \mu \mathrm{m}$ de espessura da região que contém os grupamentos dopaminérgicos A8 a A14. Experimentos anteriores indicaram que os neurônios THir são melhor identificados em cortes de $20 \mu \mathrm{m}$ do que $40 \mu \mathrm{m}$, uma vez que nestes últimos os plexos nervosos TH-ir muito densos dificultam sua visualização.

Os compartimentos A, C, D, E e F destinados ao processamento por imunoperoxidase e por imunofluorescência foram armazenados em solução anticongelante em congelador à temperatura de $-18^{\circ} \mathrm{C}$. $\mathrm{O}$ compartimento $\mathrm{B}$ destinado a coloração com tionina pelo método de Nissl para visualização da citoarquitetura foi armazenado em solução de azida de sódio a 0,02\% em geladeira àtemperatura de $4{ }^{\circ} \mathrm{C}$.

a) Reação por imunoperoxidase para visualização do FG

Os cortes histológicos do compartimento $\mathrm{D}$ foram incubados a $4^{\circ} \mathrm{C}$ por $12 \mathrm{a}$ 18 horas em solução de tampão fosfato de potássio (KPBS) $0,02 \mathrm{M}$ contendo: anticorpo policlonal anti-FG feito em coelho (Chemicon International Inc.) em concentração 1:5000, 0,3\% de Triton X-100 e 10\% de lactoproteína (leite em pó desnatado). O material foi submetido a três lavagens em KPBS 0,02 M de dez minutos cada e em seguida incubado em solução de KPBS $0,02 \mathrm{M}$ contendo anticorpo biotinilado anti-coelho feito em cabra (Vector, em concentração 1:200) e $0,3 \%$ de Triton $\mathrm{X}-100$, onde foi mantido por duas horas àtemperatura ambiente. 
Após três lavagens em KPBS 0,02 M, o material foi transferido para uma solução de KPBS 0,02 M contendo complexo peroxidase avidina-biotina (Kit Elite ABC, Vector; concentração 1:200) por duas horas à temperatura ambiente. Seguiram-se então cinco lavagens de dez minutos em KPBS 0,02 M antes da revelação do produto da reação da peroxidase através da exposição do material ao cromógeno 3,3'diaminobenzidina (DAB) de acordo com o procedimento da glucose oxidase (Itoh et al., 1979).

Ao término da reação por imunoperoxidase, os cortes foram montados em solução de KPBS 0,02 M em lâminas recobertas com gelatina alumem-cromo. A marcação retrógrada foi intensificada mergulhando-se as lâminas em uma solução de tetróxido de ósmio a $0,05 \%$ por um período de 15 a 20 segundos. O material foi então desidratado, diafanizado em xilol e recoberto com DPX.

b) Reação imunofluorescente para visualização de $F G$ e $T H$

Os cortes de $20 \mu \mathrm{m}$ de níveis contendo os grupamentos A8 a A14 de um compartimento adjacente foram incubados a $4^{\circ} \mathrm{C}$ por 48 a 72 horas em solução de KPBS 0,02 M contendo os anticorpos anti-TH feito em camundongo (Diasorin; concentração 1:1500) e anti-FG anticorpo feito em coelho (Chemicon International Inc.; concentração 1:1500), 10\% de lactoproteína e 0,3\% de Triton X-100. Após as lavagens, os cortes foram transferidos para uma solução de KPBS 0,02 M contendo o anticorpo anti-camundongo feito em cabra conjugado àfluoresceína (Jackson; concentração 1:200) e um anticorpo biotinilado anti-coelho feito em cabra (Vector; concentração 1:200) onde foram mantidos por duas horas àtemperatura ambiente. Após três lavagens em KPBS $0,02 \mathrm{M}$, o material foi mantido por duas horas à temperatura ambiente e protegido da luz em solução de KPBS 0,02 M contendo o 
cromógeno fluorescente Texas-Red conjugado a Avidina-D (Vector) diluído 1:200. Finalmente foram realizadas três lavagens de dez minutos em KPBS 0,02 M e os cortes foram então montados em lâminas previamente recobertas com gelatina alumem-cromo. Depois do tecido seco, as lâminas foram recobertas com lamínulas usando-se glicerol em tampão bicarbonato de potássio $2 \mathrm{M} \mathrm{pH} \mathrm{8,5} \mathrm{e} \mathrm{1 \%} \mathrm{do} \mathrm{anti-}$ oxidante fenil-n-diamina e armazenadas em caixas escuras àtemperatura de $-18^{\circ} \mathrm{C}$.

\subsection{Experimentos para visualização da dopamina}

Durante a perfusão, os animais receberam aproximadamente $30 \mathrm{ml}$ de solução tampão de cacodilato de sódio 0,05 M contendo ácido ascórbico $10 \mathrm{mM}, \mathrm{pH}$ 7,3 a $4^{\circ} \mathrm{C}$, seguida por um fluxo $(500 \mathrm{ml} / 15 \mathrm{~min})$ de fixador composto de glutaraldeído diluído a 5\% na mesma solução tampão a $4^{\circ} \mathrm{C}$. Os cérebros foram mantidos na calota craniana por 3 a 4 horas e o excesso de fixador foi removido passando-se um fluxo adicional de $150 \mathrm{ml}$ da mesma solução tampão a $4^{\circ} \mathrm{C}$, numa tentativa de diminuir a auto-fluorescência causada pelo glutaraldeído.

Os cérebros foram retirados da calota craniana, blocados e mantidos na mesma solução tampão. A seguir o mesencéfalo foi cortado em plano frontal no vibrátomo (Vibratome 3000, Technical Products International, INC.), sendo a espessura dos cortes $50 \mu \mathrm{m}$. Os cortes foram seriadamente distribuídos em quatro compartimentos, todos contendo solução tampão Tris $0,05 \mathrm{M}$ com ácido ascórbico $10 \mathrm{mM}, \mathrm{pH} 7,5$, sendo um deles destinado àcoloração pelo método de Nissl para visualização da citoarquitetura.

Os cortes de três compartimentos foram submetidos a três lavagens de 10 minutos em tampão Tris $0,05 \mathrm{M}$ com ácido ascórbico $10 \mathrm{mM}$ pH 7,5 àtemperatura 
ambiente. Em seguida foram mantidos por 15 minutos sob agitação em solução de $1 \%$ de boridreto de sódio diluído no mesmo tampão àtemperatura ambiente. Após outras três lavagens, os cortes foram transferidos para uma solução contendo água oxigenada a $1 \%$ e metanol a $10 \%$ diluídos no mesmo tampão por 15 minutos à temperatura ambiente. Mais três lavagens se seguiram e os cortes passaram então para uma solução contendo soro normal de cabra a $2 \%$ e Triton X-100 a 0,4\% diluídos na mesma solução de tampão por 30 minutos àtemperatura ambiente. $\mathrm{A}$ seguir, os cortes foram transferidos para uma solução de tampão Tris 0,05 M com 10 mM de ácido ascórbico pH 7,5 contendo $1 \%$ de soro normal de cabra, 0,4\% de Triton X-100 e anticorpo anti-dopamina feito em coelho (Diasorin) diluído 1:250. O material foi mantido por 48 a 72 horas sob agitação a $4^{\circ} \mathrm{C}$, em seguida lavado por 30 minutos em tampão Tris 0,05 M a temperatura ambiente e incubado em solução de Tris 0,05 M contendo anticorpo biotinilado anti-coelho feito em cabra (Vector) na concentração 1:200 por 2 horas a temperatura ambiente. Após lavagens em tampão Tris 0,05 M por 30 minutos, o material foi transferido para uma solução contendo Avidin Texas Red 1:200 por duas horas àtemperatura ambiente e protegidos da luz. Após 30 minutos de lavagens em tampão Tris $0,05 \mathrm{M}$, os cortes foram montados em lâminas gelatinadas e recobertas com lamínulas usando glicerol em tampão bicarbonato de potássio $2 \mathrm{M} \mathrm{pH} \mathrm{8,5} \mathrm{com} \mathrm{1 \%} \mathrm{de} \mathrm{anti-oxidante} \mathrm{fenil-n-diamina.}$

\subsection{Análise dos resultados}

a) Marcação retrógrada e citoarquitetura

O depósito de FG, assim como a marcação retrógrada revelada por imunoperoxidase, foram analisados em microscópio óptico utilizando-se campos 
claro e escuro. O material corado com tionina foi analisado em campo claro e serviu como referência para a identificação da citoarquitetura. A nomenclatura e definição das estruturas utilizadas na análise citoarquitetônica seguiram a terminologia adotada no atlas do cérebro de rato de Paxinos e Watson (1997).

O objetivo desta análise foi avaliar a densidade da marcação retrógrada nas áreas correspondentes aos grupamentos dopaminérgicos, e permitir delimitar com maior precisão o local efetivo de injeção. Observamos que a imunoperoxidase amplifica o sinal do FG no tecido, permitindo uma análise mais detalhada do local de injeção do que a visualização do traçador por fluorescência direta. Mesmo assim, a delimitação do local de injeção efetivo com a técnica do FG é bastante problemática; geralmente, o depósito do FG no tecido é intenso no centro da injeção, ficando mais tênue na periferia, sendo que não é possível saber com precisão até onde o traçador se espraia, e, portanto, até onde o FG pôde ser captado e transportado. Deste modo, a análise da marcação retrógrada, quando previamente conhecida, constitui um critério adicional de grande valia na delimitação do local de injeção. Assim, por exemplo, nos casos com injeção na amígdala expandida sublenticular, o grau de envolvimento do globo pálido adjacente pode ser estimado pela ocorrência de marcação retrógrada no núcleo subtalâmico. Os locais de injeção de casos representativos foram ilustrados.

b) Material fluorescente

O material revelado com cromógeno fluorescente foi analisado num microscópio Diaplan (Leitz) equipado com iluminação epifluorescente usando-se bloco de filtro A ultravioleta (com filtro de excitação BP 340-380 e barreira LP 430) para visualizar o FG; um bloco de filtro I3 azul (com filtro de excitação BP 450-490 e 
barreira LP 545) para visualizar compostos marcados com fluoresceína, e um bloco de filtro verde de rodamina (com filtro de excitação BP 515-560 e barreira LP 580) para visualizar compostos marcados com Texas Red.

As células retrogradamente e duplamente marcadas presentes nos núcleos contendo os grupamentos dopaminérgicos A8 a A14 foram contadas sistematicamente em todos os cortes de um compartimento. Os cortes possuíam espessura de $20 \mu \mathrm{m}$ e espaçamento de $160 \mu \mathrm{m}$ entre si.

As células duplamente marcadas para FG e dopamina foram contadas em cortes contendo o núcleo dorsal da rafe e a substância cinzenta periaquedutal de dois compartimentos. Os cortes possuíam espessura de $50 \mu \mathrm{m}$ e espaçamento de $100 \mu \mathrm{m}$ entre si.

Os locais de injeção, as células imunorreativas ao anticorpo anti-FG (FG-ir), e aos anticorpos anti-FG e anti-TH (FG-ir e TH-ir) dos casos representativos foram mapeados usando um programa de desenho (AutoCad R13) e uma câmera lúcida acoplada a um microscópio Diaplan e situada em frente a um monitor (Pivot 1700, Portrait Display Labs.).

As fotomicrografias foram feitas com uma câmera digital (Spot II) acoplada ao microscópio Diaplan, e o brilho e contraste das fotos foram ajustados usando-se o programa Adobe Photoshop. 


\section{RESULTADOS}

Após injeção iontoforética de traçador retrógrado FG nos núcleos que compõem a divisão central da amígdala expandida (núcleo central da amígdala, núcleo intersticial lateral da estria terminal, amígdala expandida sublenticular ou núcleo intersticial do ramo posterior da comissura anterior), identificamos as células retrogradamente marcadas presentes nos núcleos que contém os grupamentos dopaminérgicos A8 a A14 (para descrição pormenorizada destes grupamentos ver Björklund e Lindvall, 1984; Hökfelt et al., 1984; Fallon e Loughlin, 1995).

O grupamento dopaminérgico A8 está localizado no mesencéfalo e sua parte compacta (Deutch et al, 1988) corresponde ao campo retrorrubral (RR). Algumas células do A8 estão dispersas no tegmento mesencefálico ventralmente ao campo retrorrubral e, em níveis rostrais, penetram no lemnisco medial.

O grupamento A9 corresponde àsubstância negra, pars compacta e pars lateralis. A substância negra, pars compacta é, por sua vez, subdividida em um componente dorsal e outro ventral. O componente dorsal está relacionado com as projeções mesolímbicas para o prosencéfalo basal, enquanto que o componente ventral envia projeções principalmente para distritos estriatais dorsais (Fallon e Loughlin, 1995). A porção dorsal da substância negra, pars compacta, é ainda diferenciada da sua porção ventral por conter neurônios imunorreativos ao anticorpo anti-calbindina (Nemoto et al, 1999).

O grupamento A10 coincide com a área tegmental ventral, que é composta pelos núcleos parabraquial pigmentoso, paranigral, interfascicular, linear rostral da 
rafe e linear caudal da rafe (ver revisão de Oades e Halliday; 1987). Os grupamentos A8, A9 e A10 formam os grupamentos dopaminérgicos mesencefálicos ventrais.

Foram também descritas células presumivelmente dopaminérgicas (isto é, que expressam TH mas não $\mathrm{DBH}$ ) no núcleo dorsal da rafe do rato (Köhler e Goldstein, 1984; ver Stratford e Wirtshafter; 1990), gato (Miachon et al, 1984) e macaco (Charara e Parent, 1998). Em ratos, estas células dopaminérgicas se continuam ventralmente com as do núcleo linear caudal da rafe, e constituem a porção caudal e dorsal do grupamento A10 (A10dc), segundo a classificação de Hökfelt et al. (1984). O grupamento A10dc inclui ainda as células dopaminérgicas da porção lateral e juxtaquedutal da substância cinzenta periaquedutal, com as quais o núcleo dorsal da rafe não possui fronteiras precisas.

O grupamento diencefálico caudal (A11) é formado por células esparsas presentes no tálamo da linha média, no hipotálamo posterior e dorsal, na substância cinzenta periventricular do tálamo posterior e na parte rostral da substância cinzenta periaquedutal. O grupamento tuberal (A12) compreende o núcleo arqueado e células dorsais adjacentes que fazem parte do núcleo periventricular do hipotálamo.

O grupamento hipotalâmico dorsal (A13) é composto por células compactas dispostas horizontalmente no setor medial da zona incerta rostral; enquanto que o grupamento periventricular rostral (A14) é constituído pelas células dopaminérgicas do núcleo periventricular do hipotálamo.

Os grupamentos A15 e A16 correspondem a células dopaminérgicas encontradas na retina e no bulbo olfatório respectivamente. Como não há descrição de projeções destes territórios para a amígdala expandida central ou para a concha do acumbens, estes grupamentos não foram considerados em nossa análise. 


\subsection{CASOS COM INJEÇÃO NO NÚCLEO CENTRAL DA AMÍGDALA}

De 30 animais que receberam injeção de FG tendo como alvo o núcleo central da amígdala, em sete casos a injeção de FG estava praticamente confinada a este núcleo. Tomadas em conjunto, estas injeções envolveram aproximadamente toda extensão rostrocaudal deste núcleo (Fig. 3). Em quatro destes casos (233, 234, 236 e 343), o centro da injeção estava localizado na metade rostral do núcleo central da amígdala, em dois casos (345 e 351) na sua porção intermédia, e em um caso (350) na sua metade caudal. Em todos os casos, o depósito de FG abarcou todas as subdivisões do núcleo amigdalóide central. Nos casos 233 e 234, a injeção de FG acometeu principalmente a divisão medial do núcleo central da amígdala. No caso 345, o depósito de FG abarcou principalmente suas divisões lateral e capsular, envolvendo em menor grau a divisão medial do núcleo central da amígdala. Foi observado um pequeno acometimento periférico do núcleo basolateral da amígdala no caso 345, e da porção dorsal do núcleo medial da amígdala no caso 233.

Resultados semelhantes foram encontrados em todos esses casos no que diz respeito àdistribuição das células retrogradamente e duplamente marcadas (Figs. 4a e 4b; Tabelas 1 e 2) e àcontribuição relativa de cada grupamento dopaminérgico para a inervação do núcleo amigdalóide central (Fig. 5).

O caso 350 foi escolhido como representativo e será descrito em detalhes (Fig. 4a). De maneira geral, foi observado que a inervação dopaminérgica do núcleo central da amígdala se origina de estruturas mesencefálicas ipsolaterais. Os grupamentos dopaminérgicos diencefálicos praticamente não contribuem para a inervação do núcleo central da amígdala. 

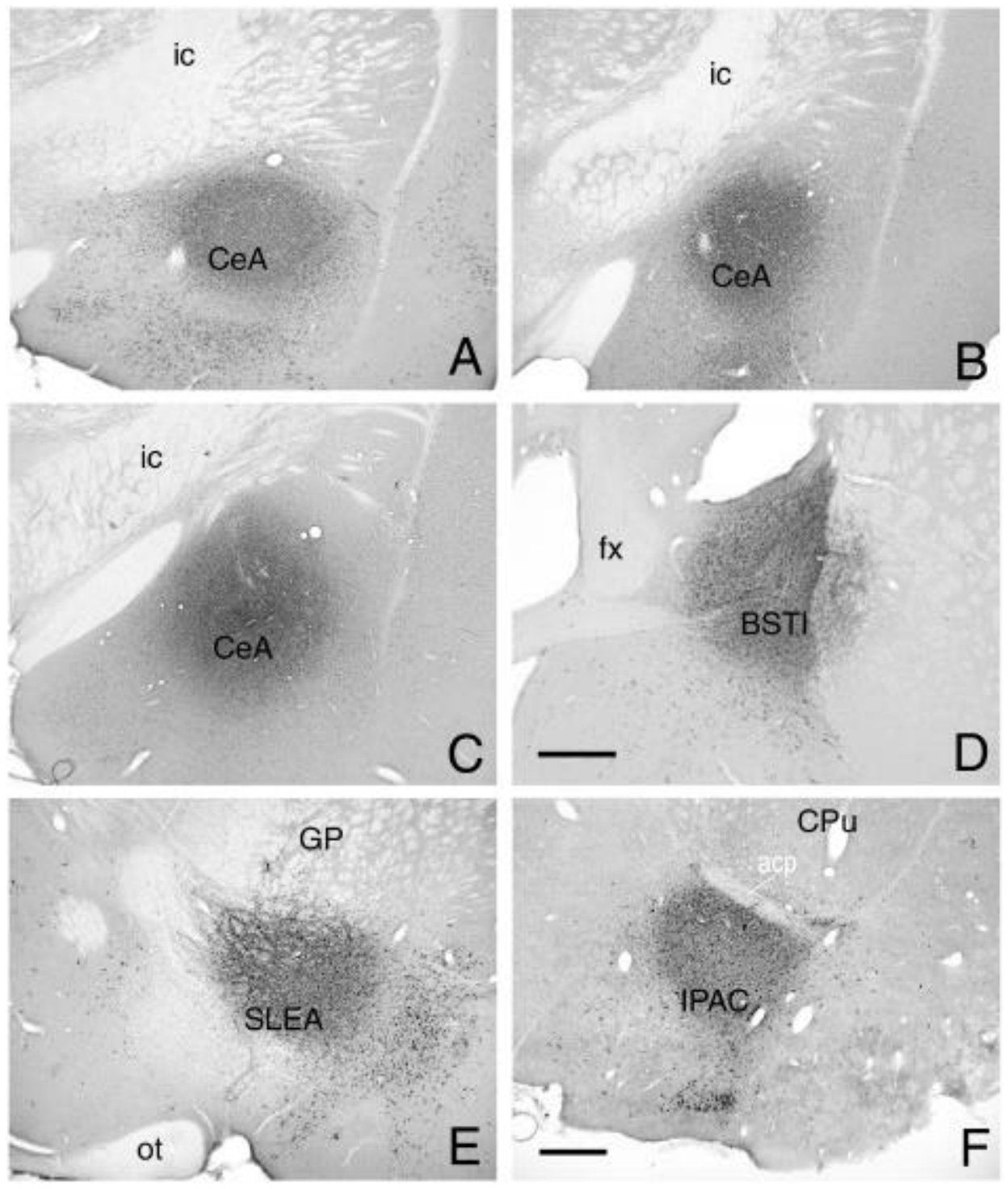

Figura 3: Fotomicrografias de campo claro ilustrando o local de injeção de FG no núcleo amigdalóide central (A: caso 343; B: caso 350; C: caso 349), núcleo intersticial lateral da estria terminal (D: caso 240), amígdala expandida sublenticular (E: caso 334) e núcleo intersticial do ramo posterior da comissura anterior ( $F$ : caso 266). Barras de escala em $D$ e $F$ (também válida para $A, B, C$ e E) $=500 \mu \mathrm{m}$. Para abreviaturas, ver lista. 


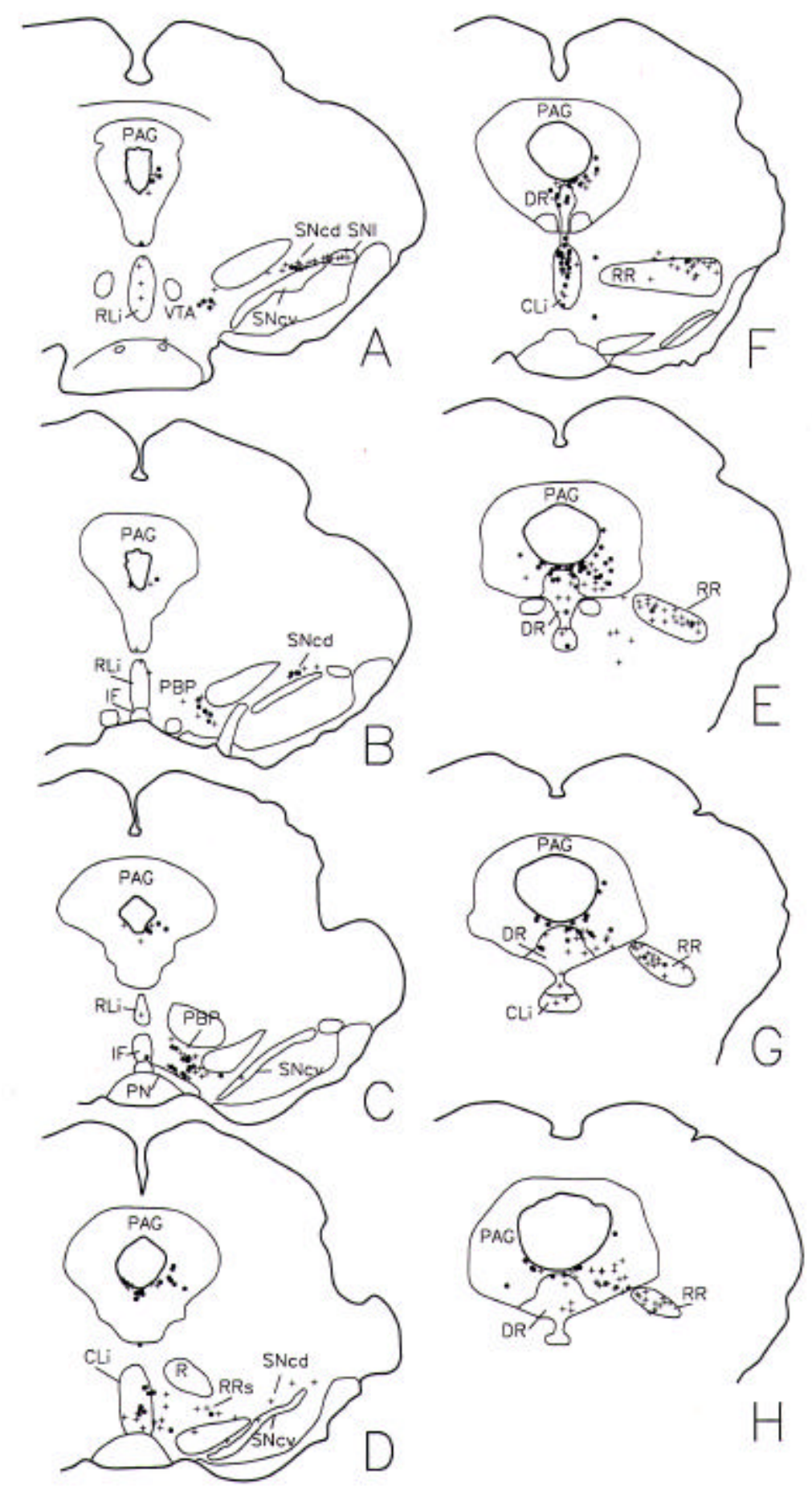

Figura 4a: Representação esquemática da distribuição das células contendo FG (cruzes) e FG e TH (pontos) no caso 350, com injeção no núcleo central da amígdala. Cada símbolo representa uma célula. Para abreviaturas, ver lista. 

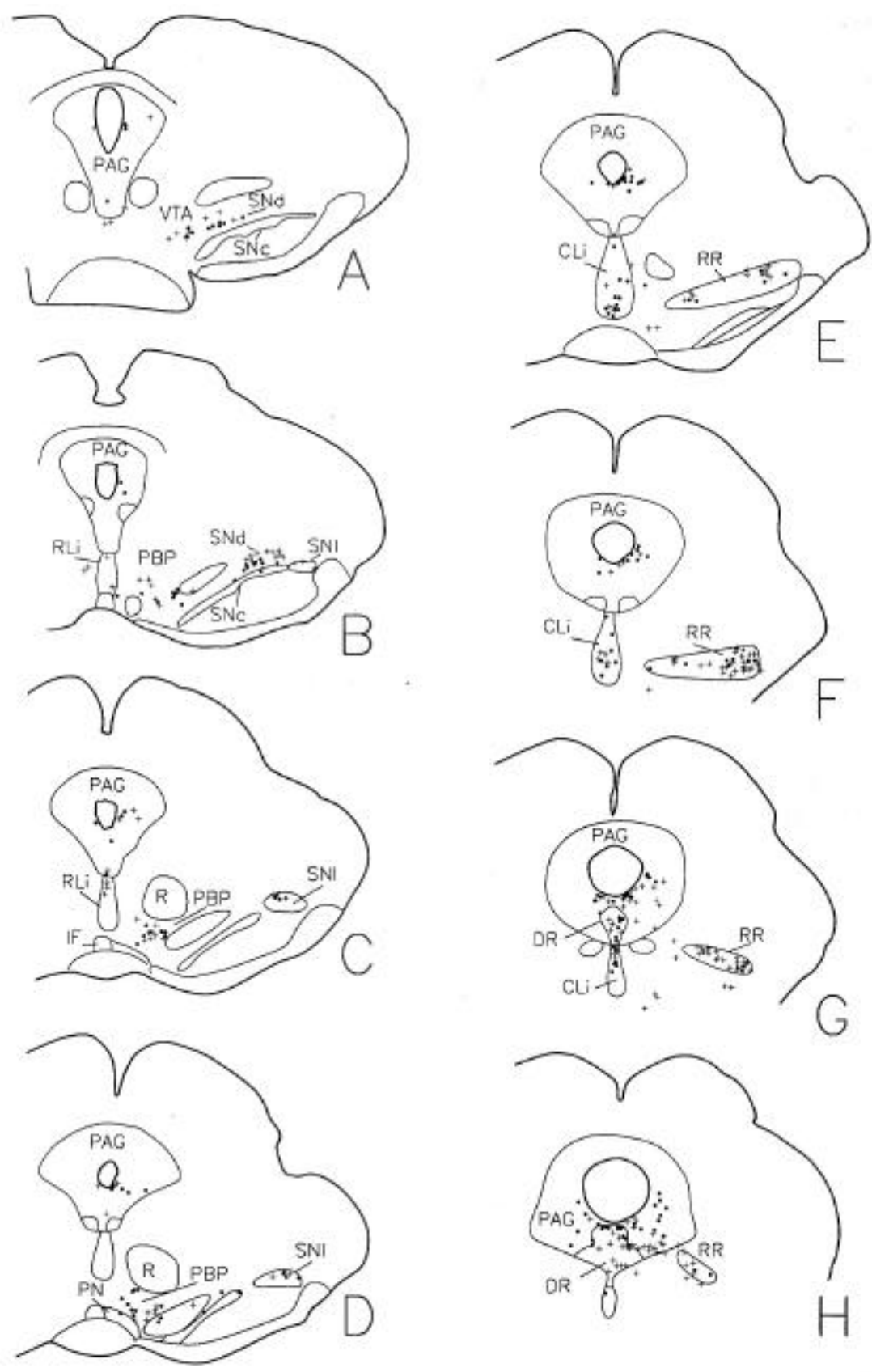

Figura 4b: Representação esquemática da distribuição das células contendo FG (cruzes) e FG e TH (pontos) no caso 343, com injeção no núcleo central da amígdala. Cada símbolo representa uma célula. Para abreviaturas, ver lista. 
Figura 5: Porcentagem de células* duplamente marcadas encontradas em cada grupamento dopaminérgico em relação ao total visto por caso após injeção de FG no núcleo central da amígdala.

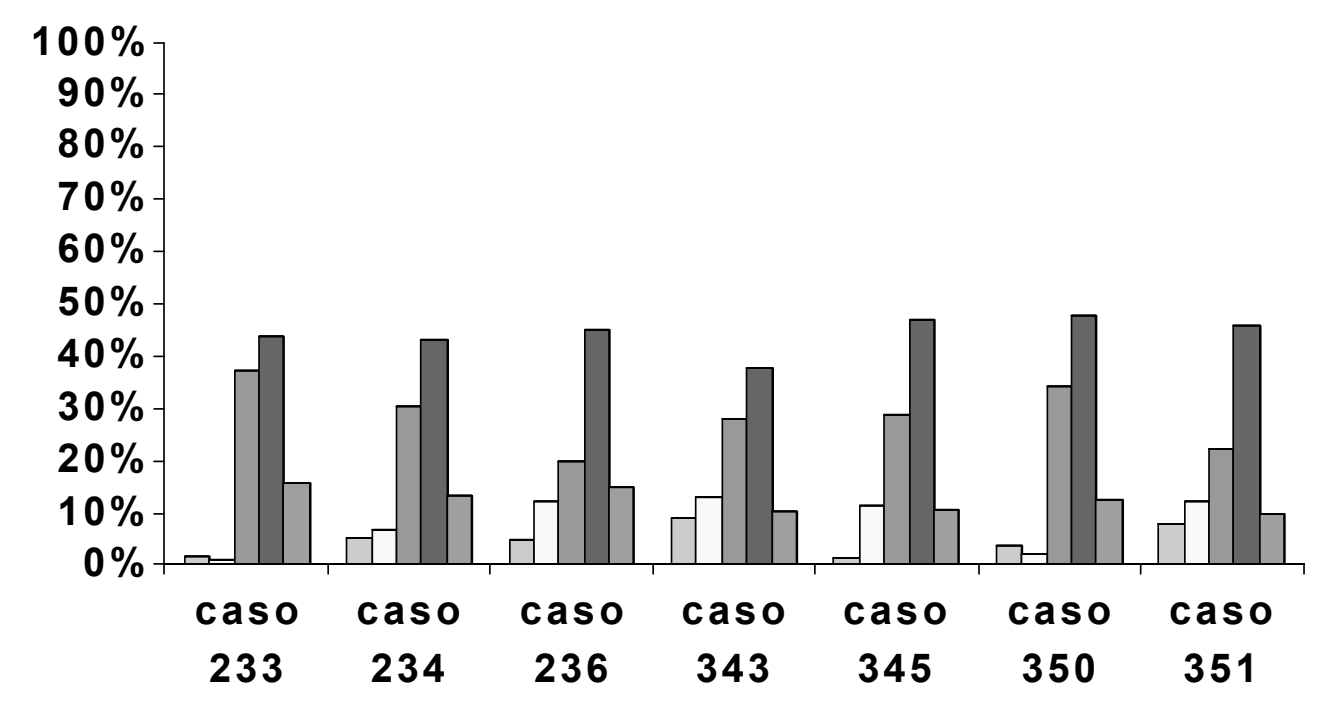

$\square$ A8/RR $\square$ A9/SN $\square$ A10/VTA $\square$ A10dc/PAG $\square$ A10dc/DR

* as células foram contadas em um compartimento, sendo o intervalo entre os cortes adjacentes de $160 \mu \mathrm{m}$.

\section{Diencéfalo}

No hipotálamo, um número moderado de células retrogradamente marcadas foi visto nos núcleos arqueado e periventricular. A zona incerta medial possui apenas uma marcação retrógrada modesta (Tabela 1).

Numerosas células retrogradamente marcadas foram observadas na porção posterior do tálamo, ao longo da linha média, i.e., nos núcleos paraventricular posterior, intermédio dorsal, posteromediano, central medial, porção medial do núcleo parafascicular, e porção magnocelular do núcleo subparafascicular. Esta marcação, de modo geral, está localizada dorsolateralmente ao grupamento A11, existindo apenas pequeno embricamento entre estas duas populações.

No caso 350 não foram vistas células duplamente marcadas na porção talâmica do grupo A11 e nos grupos A12, A13, A14. Em outros casos com injeção no 
núcleo central da amígdala, células FG-ir e TH-ir foram ocasionalmente vistas no grupamento A13, e apenas o caso 343 apresentou uma única célula duplamente marcada na porção talâmica do A11. Caudalmente, as células do grupo A11 invadem a substância cinzenta periventricular, onde foram vistas algumas células duplamente marcadas em todos os casos com injeção no núcleo amigdalóide central (Tabela 2).

Tabela 1: Número* de células contendo FG observadas nos núcleos correspondentes aos grupamentos dopaminérgicos mesodiencefálicos após injeção de FG no núcleo central da amígdala.

\begin{tabular}{|c|c|c|c|c|c|c|c|c|}
\hline \multicolumn{2}{|c|}{ caso } & 233 & 234 & 236 & 343 & 345 & 350 & 351 \\
\hline A8 & $\mathrm{RR}$ & 38 & 151 & 72 & 180 & 83 & 129 & 140 \\
\hline \multirow[t]{3}{*}{ A9 } & SNcd & 26 & 56 & 39 & 53 & 52 & 46 & 58 \\
\hline & SNcv & 6 & 15 & 7 & 2 & 1 & 1 & 0 \\
\hline & SNI & 1 & 17 & 3 & 35 & 27 & 10 & 27 \\
\hline \multirow[t]{5}{*}{ A10 } & PBP & 60 & 127 & 25 & 118 & 95 & 111 & 97 \\
\hline & PN & 0 & 9 & 7 & 3 & 2 & 0 & 1 \\
\hline & RLi & 8 & 28 & 3 & 31 & 10 & 13 & 10 \\
\hline & CLi & 50 & 55 & 34 & 68 & 44 & 67 & 48 \\
\hline & IF & 3 & 5 & 3 & 6 & 3 & 5 & 3 \\
\hline \multicolumn{2}{|c|}{$\mathrm{A} 8 / \mathrm{A} 9 / \mathrm{A} 10^{* *}$} & 8 & 10 & 14 & 25 & 10 & 0 & 10 \\
\hline A10dc & PAG & 130 & 319 & 133 & 271 & 195 & 244 & 241 \\
\hline A10dc & DR & 85 & 119 & 47 & 131 & 148 & 115 & 98 \\
\hline A11 & SCPV & 20 & 12 & 5 & 43 & 43 & 18 & 25 \\
\hline A12 & Arq & 52 & 54 & 2 & 45 & 14 & 68 & 39 \\
\hline A13 & ZIm & 17 & 6 & 5 & 10 & 7 & 9 & 6 \\
\hline A14 & PVH & 25 & 7 & 2 & 15 & 23 & 59 & 2 \\
\hline \multicolumn{2}{|c|}{ TOTAL } & 529 & 990 & 401 & 1036 & 757 & 895 & 805 \\
\hline
\end{tabular}

${ }^{*}$ as células foram contadas em um compartimento, sendo o intervalo entre os cortes adjacentes de $160 \mu \mathrm{m}$.

** Os limites entre os grupamentos A8, A9 e A10 são mal definidos e a categoria representada por A8/A9/A10 se refere ao número de células observadas nas áreas de transição entre estes grupamentos dopaminérgicos. 
Tabela 2: Número* de células contendo FG e TH encontradas nos grupamentos dopaminérgicos mesodiencefálicos após injeção de FG no núcleo central da amígdala.

\begin{tabular}{|c|c|c|c|c|c|c|c|c|}
\hline \multicolumn{2}{|c|}{ caso } & 233 & 234 & 236 & 343 & 345 & 350 & 351 \\
\hline A8 & $\mathrm{RR}$ & 3 & 18 & 7 & 41 & 4 & 12 & 30 \\
\hline \multirow[t]{3}{*}{ A9 } & SNcd & 2 & 16 & 13 & 33 & 19 & 6 & 28 \\
\hline & SNcv & 0 & 3 & 2 & 2 & 0 & 0 & 0 \\
\hline & SNI & 0 & 4 & 3 & 22 & 13 & 1 & 19 \\
\hline \multirow[t]{5}{*}{ A10 } & PBP & 31 & 50 & 9 & 65 & 43 & 60 & 48 \\
\hline & PN & 0 & 7 & 1 & 2 & 2 & 0 & 1 \\
\hline & RLi & 4 & 5 & 1 & 3 & 4 & 3 & 1 \\
\hline & CLi & 28 & 35 & 16 & 51 & 29 & 46 & 32 \\
\hline & IF & 2 & 4 & 3 & 4 & 2 & 1 & 3 \\
\hline \multicolumn{2}{|c|}{$\mathrm{A} 8 / \mathrm{A} 9 / \mathrm{A} 10$} & 0 & 4 & 4 & 6 & 2 & 0 & 8 \\
\hline A10dc & PAG & 72 & 140 & 62 & 165 & 121 & 150 & 167 \\
\hline A10dc & DR & 27 & 44 & 22 & 46 & 30 & 40 & 38 \\
\hline A11 & SCPV & 4 & 2 & 4 & 2 & 9 & 3 & 8 \\
\hline A12 & Arq & 0 & 0 & 0 & 0 & 0 & 0 & 0 \\
\hline A13 & ZIm & 1 & 0 & 0 & 1 & 0 & 0 & 0 \\
\hline A14 & PVH & 0 & 0 & 0 & 0 & 0 & 0 & 0 \\
\hline \multicolumn{2}{|c|}{ TOTAL } & 174 & 332 & 174 & 443 & 278 & 322 & 383 \\
\hline
\end{tabular}

* as células foram contadas em um compartimento, sendo o intervalo entre os cortes adjacentes de $160 \mu \mathrm{m}$.

\section{Mesencéfalo}

A marcação retrógrada no mesencéfalo é densa na substância cinzenta periaquedutal e no núcleo dorsal da rafe, moderada na área tegmental ventral e no campo retrorrubral, e modesta na substância negra. (Tabela 1; Figs. 4a).

Os grupamentos dopaminérgicos mesencefálicos ventrais (A8, A9 e A10) contém cerca de $40 \%$ do número total de células duplamente marcadas observadas no caso 350. A maior parte das células duplamente marcadas está distribuída no 
grupamento A10dc do núcleo dorsal da rafe (quase 15\%) e substância cinzenta periaquedutal (cerca de 45\%; Fig. 5, Tabelas 3 e 4).

Campo retrorrubral

As células retrogradamente marcadas distribuem-se ao longo de toda a extensão rostrocaudal do campo retrorrubral, com uma discreta predominância no setor lateral (Fig. 4a). Observamos que quase 10\% das células retrogradamente marcadas no campo retrorrubral são também positivas para TH. A maioria delas se encontra na parte compacta do A8, preferencialmente em sua porção rostral, representando ao redor de $4 \%$ do total de células duplamente marcadas encontradas neste caso (Tabela 3).

Substância negra

A marcação retrógrada na substância negra está principalmente na porção dorsal da pars compacta, e em menor grau, na pars lateralis (Figs. 4a). As células do grupamento A9 que são FG-ir e TH-ir totalizam cerca de $2 \%$ do total de células duplamente marcadas encontradas neste caso (Tabela 3).

Tabela 3 : Porcentagem de células* duplamente marcadas encontradas em cada grupamento dopaminérgico do mesencéfalo ventral em relação ao total visto por caso com injeção de FG no núcleo central da amígdala.

\begin{tabular}{c|ccccccc}
\hline caso & 233 & 234 & 236 & 343 & 345 & 350 & 351 \\
\hline A8/RR & $1.7 \%$ & $\mathbf{5 . 4 \%}$ & $\mathbf{4 , 7 \%}$ & $\mathbf{9 . 2} \%$ & $\mathbf{1 . 4 \%}$ & $\mathbf{3 . 7 \%}$ & $\mathbf{7 . 8 \%}$ \\
A9/SN & $\mathbf{1 . 1 \%}$ & $\mathbf{6 . 9 \%}$ & $\mathbf{1 2 , 2} \%$ & $\mathbf{1 2 . 8 \%}$ & $\mathbf{1 1 . 5 \%}$ & $\mathbf{2 . 2} \%$ & $\mathbf{1 2 . 2} \%$ \\
A10/VTA & $\mathbf{3 7 . 3 \%}$ & $\mathbf{3 0 . 3} \%$ & $\mathbf{2 0 \%}$ & $\mathbf{2 8 . 1} \%$ & $\mathbf{2 8 . 8} \%$ & $\mathbf{3 4 . 2} \%$ & $\mathbf{2 2 . 1 \%}$ \\
\hline
\end{tabular}

* as células foram contadas em um compartimento, sendo o intervalo entre os cortes adjacentes de $160 \mu \mathrm{m}$.

Área Tegmental Ventral 
As células FG-ir estão heterogeneamente distribuídas por entre os diferentes núcleos que compõem a área tegmental ventral (Tabela 1). Elas foram encontradas principalmente no setor dorsolateral do núcleo parabraquial pigmentoso e no núcleo linear caudal da rafe (Figs. 4a), sendo observado apenas um pequeno número nos núcleos paranigral, linear rostral da rafe e interfascicular.

Aproximadamente metade das células FG-ir da área tegmental ventral são também positivas para $\mathrm{TH}$, somando ao redor de $35 \%$ das células duplamente marcadas vistas no caso 350 (Tabela 3). Destas, cerca de $20 \%$ estão no setor dorsolateral do núcleo parabraquial pigmentoso e cerca de 15\% no núcleo linear caudal da rafe. A Figura 7 mostra a distribuição relativa das células duplamente marcadas nos núcleos da área tegmental ventral.

Figura 7: Porcentagem de células* duplamente marcadas em cada subnúcleo em relação ao total de células duplamente marcadas na área tegmental ventral após injeção de FG no núcleo central da amígdala.

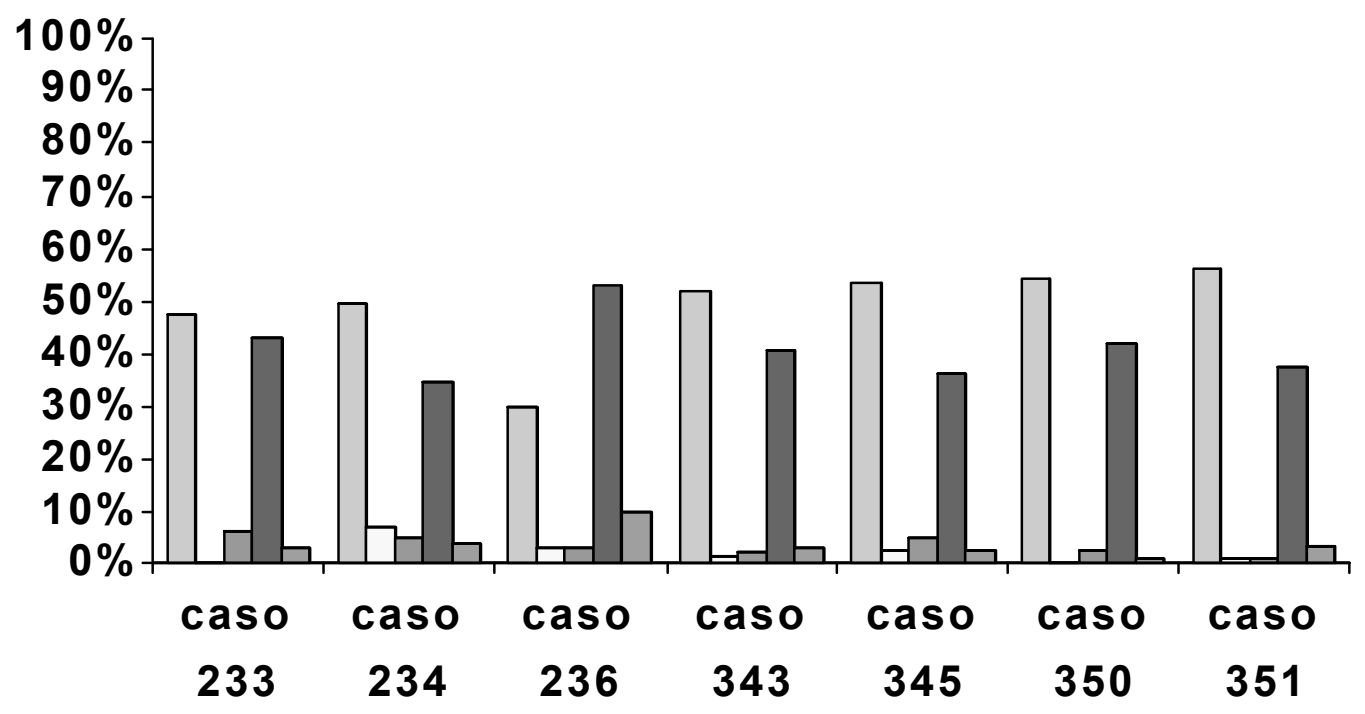

\section{PBP $\square$ PN $\square$ RLi $\square$ CLi $\square$ IF}

* as células foram contadas em um compartimento, sendo o intervalo entre os cortes adjacentes de $160 \mu \mathrm{m}$. 

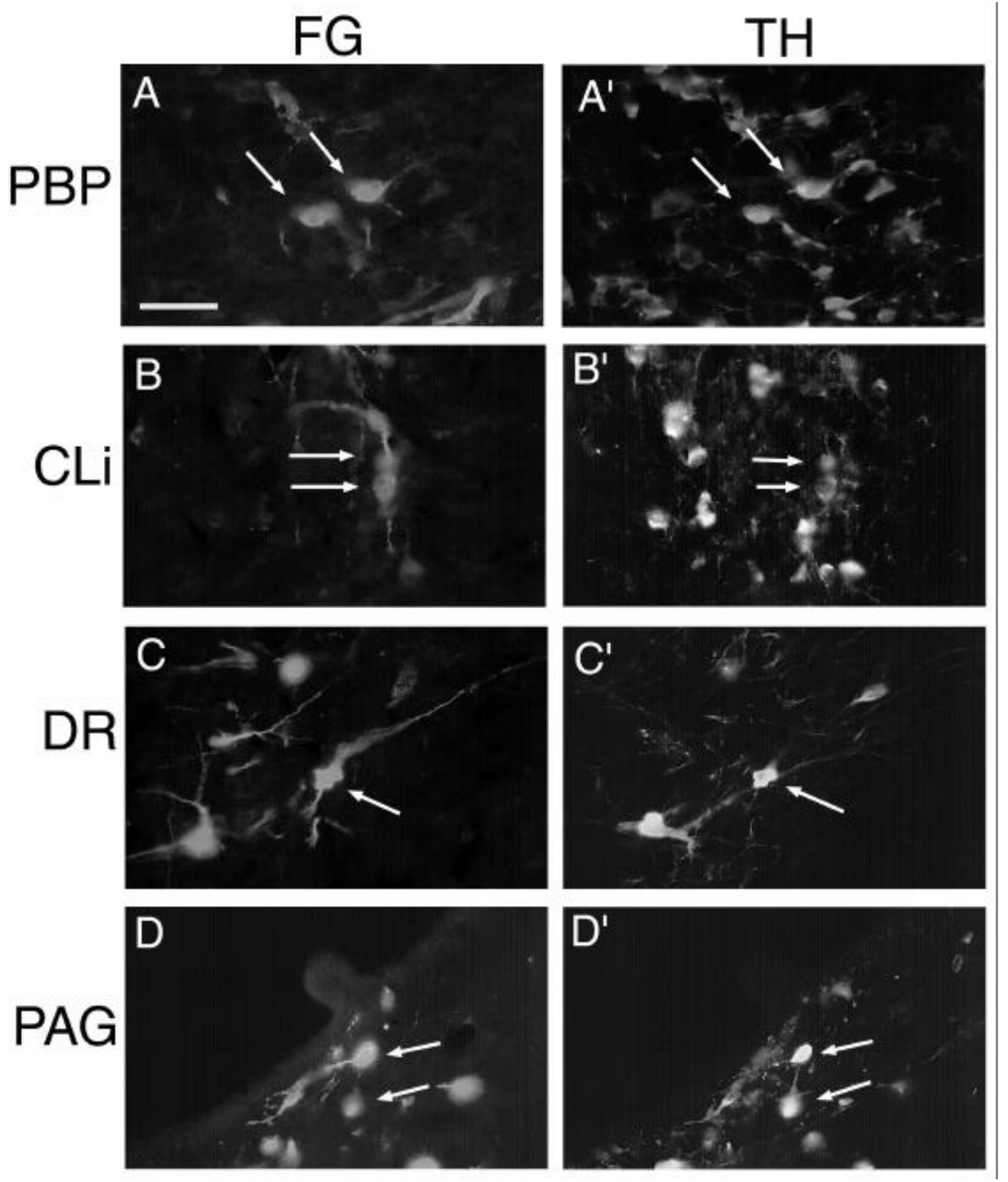

Figura 6: Fotomicrografias de células duplamente marcadas (indicadas pelas setas) presentes nos grupamentos dopaminérgicos do mesencéfalo após injeção de $F G$ no núcleo central da amígdala. Células contendo FG: coluna àesquerda; células contendo $T H$ : colu na àdireita. $A$-A': núcleo parabraquial pigmentoso; B-B': núcleo linear caudal da rafe; C-C': núcleo dorsal da rafe; D-D': substância cinzenta periaquedutal. Barra de escala em A (válida também para os demais campos) $=50 \mu \mathrm{m}$. Para abreviaturas, ver lista. 
Substância Cinzenta Periaquedutal

Numerosas células retrogradamente marcadas foram observadas na substância cinzenta periaquedutal em níveis caudais (de 7,0 mm a 8,3 mm caudal ao bregma, Tabela 1; Figs. 4a). Estes neurônios FG-ir concentram-se essencialmente nas colunas lateral e ventrolateral da substância cinzenta periaquedutal, sendo que ao redor de 60\% deles são também TH-ir (Fig. 6). A substância cinzenta periaquedutal, que corresponde ao grupamento A10dc, contém por volta de $45 \%$ do número de células duplamente marcadas vistas neste caso (Fig. 5;Tabela 4).

Tabela 4: Porcentagem de células* duplamente marcadas na substância cinzenta central e no núcleo dorsal da rafe em relação ao total visto por caso com injeção de FG no núcleo central da amígdala.

\begin{tabular}{c|ccccccc}
\hline caso & 233 & 234 & 236 & 343 & 345 & 350 & 351 \\
\hline A11/SCPV & $2.3 \%$ & $0.6 \%$ & $2,7 \%$ & $0.4 \%$ & $3.2 \%$ & $0.9 \%$ & $2 \%$ \\
A10dc/PAG & $41.3 \%$ & $42 \%$ & $42,1 \%$ & $37.1 \%$ & $43.5 \%$ & $46.6 \%$ & $43.5 \%$ \\
A10dc/DR & $15.5 \%$ & $13.2 \%$ & $15 \%$ & $10.4 \%$ & $10.8 \%$ & $12.4 \%$ & $9.9 \%$ \\
\hline
\end{tabular}

${ }^{*}$ as células foram contadas em um compartimento, sendo o intervalo entre os cortes adjacentes de $160 \mu \mathrm{m}$.

Núcleo Dorsal da Rafe

O núcleo dorsal da rafe apresenta uma marcação retrógrada moderada em toda sua extensão, salvo em sua porção mais caudal, onde a marcação retrógrada é menos intensa (Figs. 4a). No caso 350, aproximadamente 35\% destas células são também TH-ir e representam um pouco mais de $10 \%$ de todas as células duplamente marcadas encontradas (Figs. 4a e 6; Tabela 4). 


\subsection{CASOS COM INJEÇÃO NO NÚCLEO INTERSTICIAL LATERAL DA ESTRIA} TERMINAL

De 17 animais que receberam injeção de FG tendo como alvo o núcleo intersticial lateral da estria terminal, em dois casos (240 e 243) a injeção de FG estava praticamente confinada a este núcleo. No caso 240, a injeção de FG está centrada no núcleo intersticial lateral da estria terminal, envolvendo suas porções dorsal, posterior e juxtacapsular, e acomete perifericamente as colunas lateral e intermédia da porção posterior do núcleo intersticial medial da estria terminal (Fig. 3). A injeção de FG no caso 243 é semelhante àdo caso 240, porém é mais extensa no sentido rostrocaudal, e envolve mais apreciavelmente o núcleo intersticial medial da estria terminal e a porção ventral do núcleo intersticial lateral da estria terminal.

Resultados semelhantes foram encontrados nestes dois casos. A distribuição das células retrogradamente e duplamente marcadas (Fig. 12; Tabelas 5 e 6) e a contribuição relativa de cada grupamento dopaminérgico para a inervação do núcleo intersticial lateral da estria terminal (Fig. 13) no caso mais marcado (caso 240) será descrita em detalhes.

Assim como nos casos com injeção no núcleo central da amígdala, a inervação dopaminérgica do núcleo intersticial lateral da estria terminal se origina quase que exclusivamente de estruturas mesencefálicas ipsolaterais, sendo mínima a contribuição dos grupamentos dopaminérgicos diencefálicos.

\section{Diencéfalo}

A marcação retrógrada é moderada nos núcleos arqueado e periventricular do hipotálamo, e bastante modesta na zona incerta medial (Tabela 5). 

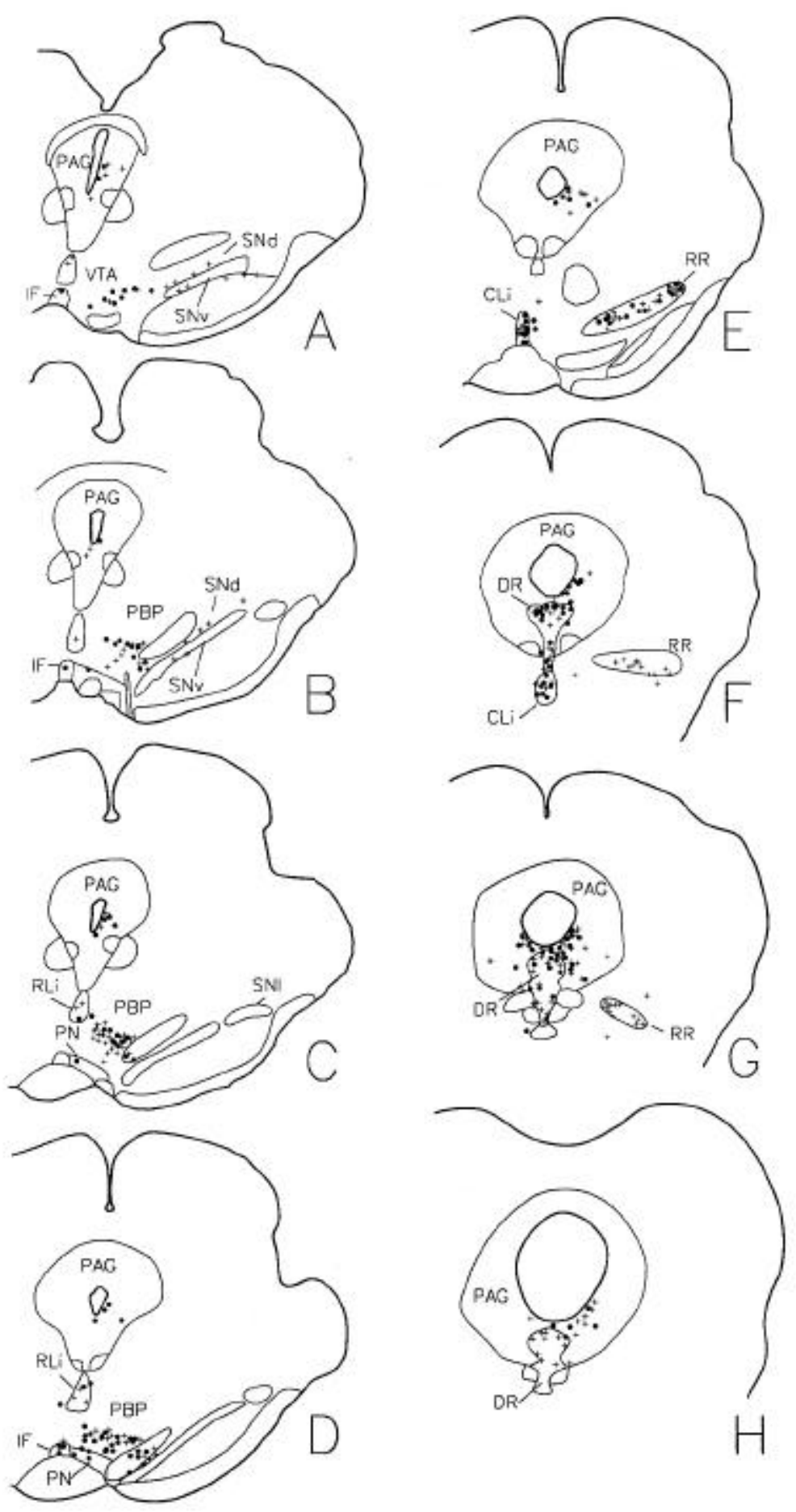

Figura 8: Representação esquemática da distribuição das células contendo FG (cruzes) e FG e TH (pontos) no caso 240, com injeção no núcleo intersticial lateral da estria terminal. Cada símbolo representa uma célula. Para abreviaturas, ver lista. 
Figura 9: Porcentagem de células* duplamente marcadas encontradas em cada grupamento dopaminérgico em relação ao total visto por caso com injeção de FG no núcleo intersticial lateral da estria terminal.

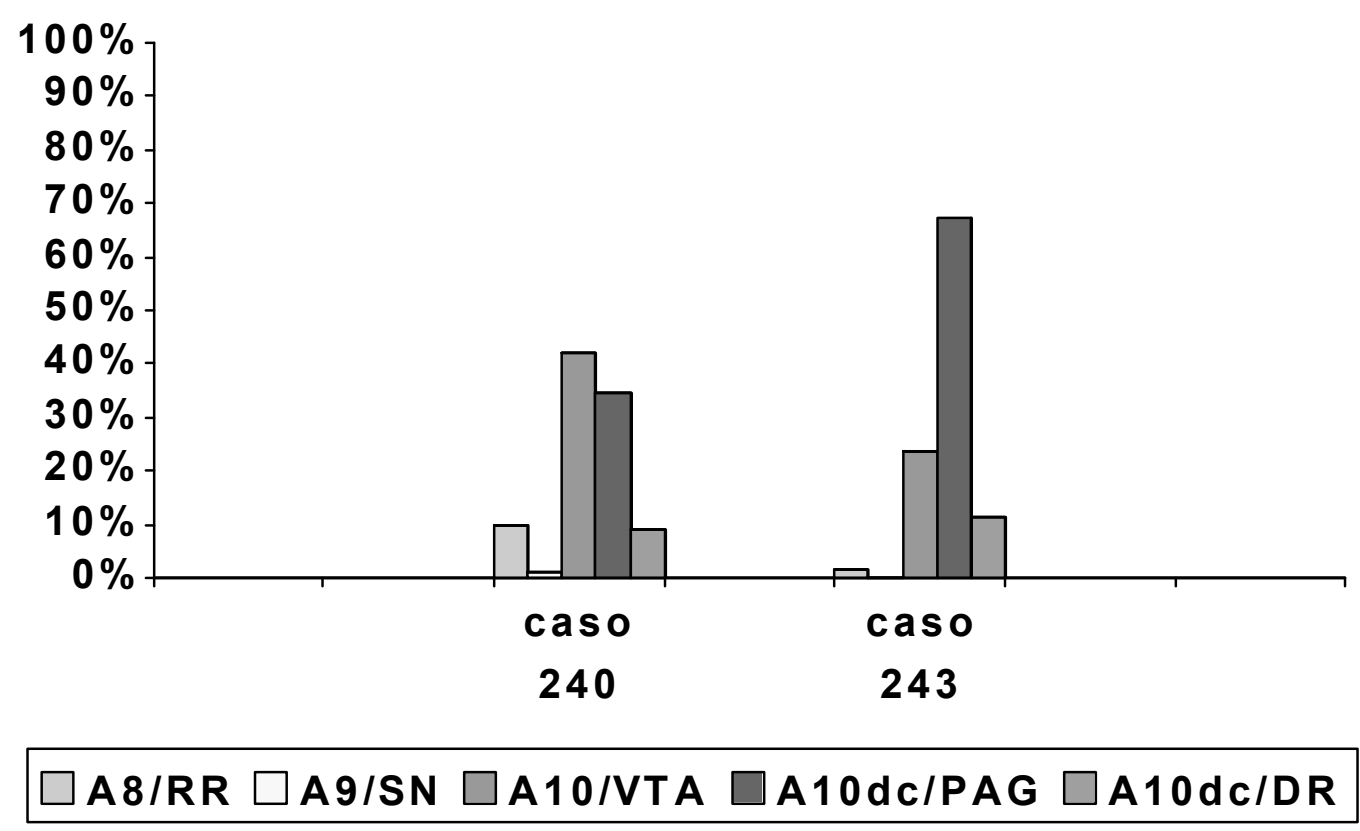

* as células foram contadas em um compartimento, sendo o intervalo entre os cortes adjacentes de $160 \mu \mathrm{m}$.

No tálamo posterior, a marcação retrógrada é intensa ao longo da linha média, i.e., nos núcleos paraventricular posterior, intermédio dorsal, posteromediano, central medial, porção medial do núcleo parafascicular, e porção magnocelular do núcleo subparafascicular. Assim como nos casos com injeção no núcleo central da amígdala, as células retrogradamente marcadas situam-se dorsal e lateralmente ao grupamento A11, existindo apenas pouco embricamento entre estas duas populações. Células FG-ir do tálamo posterior invadem caudalmente a substância cinzenta periventricular, onde coexistem com o grupamento A11.

Poucas células duplamente marcadas foram vistas no grupo A14, assim como na substância cinzenta periventricular, que faz parte do grupamento A11 (Tabelas 6 e 8). Não foram observadas células FG-ir e àTH-ir nos grupos A13, A12 e na porção 
talâmica do grupo A11. Resultados muito semelhantes foram obtidos no caso 243, sendo que neste, uma célula duplamente marcada pôde ser identificada no grupo A13 (Tabelas 6 e 8).

Tabela 5: Número* de células contendo FG observadas nos núcleos correspondentes aos grupamentos dopaminérgicos mesodiencefálicos após injeção de FG no núcleo intersticial lateral da estria terminal.

\begin{tabular}{|c|c|c|c|}
\hline \multicolumn{2}{|c|}{ caso } & \multirow{2}{*}{$\begin{array}{l}240 \\
153\end{array}$} & \multirow{2}{*}{$\begin{array}{l}243 \\
120\end{array}$} \\
\hline A8 & $\mathrm{RR}$ & & \\
\hline \multirow[t]{3}{*}{ A9 } & SNcd & 33 & 38 \\
\hline & SNcV & 24 & 13 \\
\hline & SNI & 7 & 7 \\
\hline \multirow[t]{5}{*}{ A10 } & PBP & 127 & 56 \\
\hline & PN & 10 & 9 \\
\hline & RLi & 15 & 12 \\
\hline & CLi & 100 & 56 \\
\hline & IF & 25 & 3 \\
\hline \multicolumn{2}{|c|}{ A8/A9/A10 } & 11 & 8 \\
\hline A10dc & PAG & 286 & 273 \\
\hline A10dc & DR & 106 & 59 \\
\hline A11 & SCPV & 36 & 21 \\
\hline A12 & Arq & 112 & 30 \\
\hline A13 & ZIm & 24 & 32 \\
\hline A14 & PVH & 89 & 36 \\
\hline \multicolumn{2}{|c|}{ TOTAL } & 1158 & 773 \\
\hline
\end{tabular}

* as células foram contadas em um compartimento, sendo o intervalo entre os cortes adjacentes de $160 \mu \mathrm{m}$.

\section{Mesencéfalo}

A inervação dopaminérgica do núcleo intersticial lateral da estria terminal se origina quase exclusivamente do mesencéfalo, sendo que metade provém dos 
grupamentos mesencefálicos ventrais (A8, A9 e A10) e a outra metade do núcleo dorsal da rafe e da substância cinzenta periaquedutal (A10dc; Fig. 12; Tabela 6).

Tabela 6: Número* de células contendo FG e TH encontradas nos grupamentos dopaminérgicos mesodiencefálicos após injeção de FG no núcleo intersticial lateral da estria terminal.

\begin{tabular}{cc|cc}
\hline \multicolumn{2}{r|}{ caso } & 240 & 243 \\
\hline A8 & RR & 38 & 2 \\
A9 & SNcd & 1 & 0 \\
& SNcv & 3 & 0 \\
& SNI & 1 & 0 \\
A10 & PBP & 68 & 12 \\
& PN & 10 & 6 \\
& RLi & 2 & 1 \\
& CLi & 65 & 13 \\
& IF & 18 & 1 \\
A8/A9/A10 & 6 & 1 \\
A10dc & PAG & 133 & 86 \\
A10dc & DR & 35 & 16 \\
A11 & SCPV & 2 & 2 \\
A12 & Arq & 0 & 0 \\
A13 & Zlm & 0 & 1 \\
A14 & PVH & 2 & 3 \\
\multicolumn{2}{c}{ TOTAL } & 384 & 144 \\
\hline
\end{tabular}

* as células foram contadas em um compartimento, sendo o intervalo entre os cortes adjacentes de $160 \mu \mathrm{m}$.

Campo retrorrubral

As marcação retrógrada no campo retrorrubral é homogênea em toda sua extensão (Fig. 12), e está localizada exclusivamente na sua parte compacta. Cerca 
de um quarto destas células são também TH-ir, representando quase $10 \%$ do total de células duplamente marcadas encontradas neste caso (Fig. 13; Tabela 7).

Substância negra

As células nigrais retrogradamente marcadas estão localizadas na sua pars compacta, principalmente na sua porção dorsal, mas também na pars lateralis (Fig. 12). Foram vistas poucas células duplamente marcadas no A9, e estas representam cerca de $1 \%$ do total de células duplamente marcadas encontradas neste caso (Tabelas 6 e 7).

Tabela 7 : Porcentagem de células* duplamente marcadas encontradas em cada grupamento dopaminérgico do mesencéfalo ventral em relação ao total visto por caso com injeção de FG no núcleo intersticial lateral da estria terminal.

\begin{tabular}{c|cc}
\hline caso & 240 & 243 \\
\hline A8/RR & $9.8 \%$ & $1.4 \%$ \\
A9/SN & $1.2 \%$ & 0 \\
A10/VTA & $42.2 \%$ & $23.6 \%$ \\
\hline
\end{tabular}

* as células foram contadas em um compartimento, sendo o intervalo entre os cortes adjacentes de $160 \mu \mathrm{m}$.

Área Tegmental Ventral

Assim como nos casos com injeção no núcleo central da amígdala, a células retrogradamente marcadas estão em sua maioria no setor dorsolateral do núcleo parabraquial pigmentoso e no núcleo linear caudal da rafe; um número mais modesto de células FG-ir foi visto nos núcleos paranigral, interfascicular e linear rostral da rafe (Tabela 5; Figs. 12 e 11).

Dentre as células FG-ir na área tegmental ventral, pouco mais da metade são também TH-ir (Fig. 10). Tomadas em conjunto, as células duplamente marcadas no grupamento A10 perfazem cerca de $40 \%$ do total visto no caso 240 (Tabela 7), 

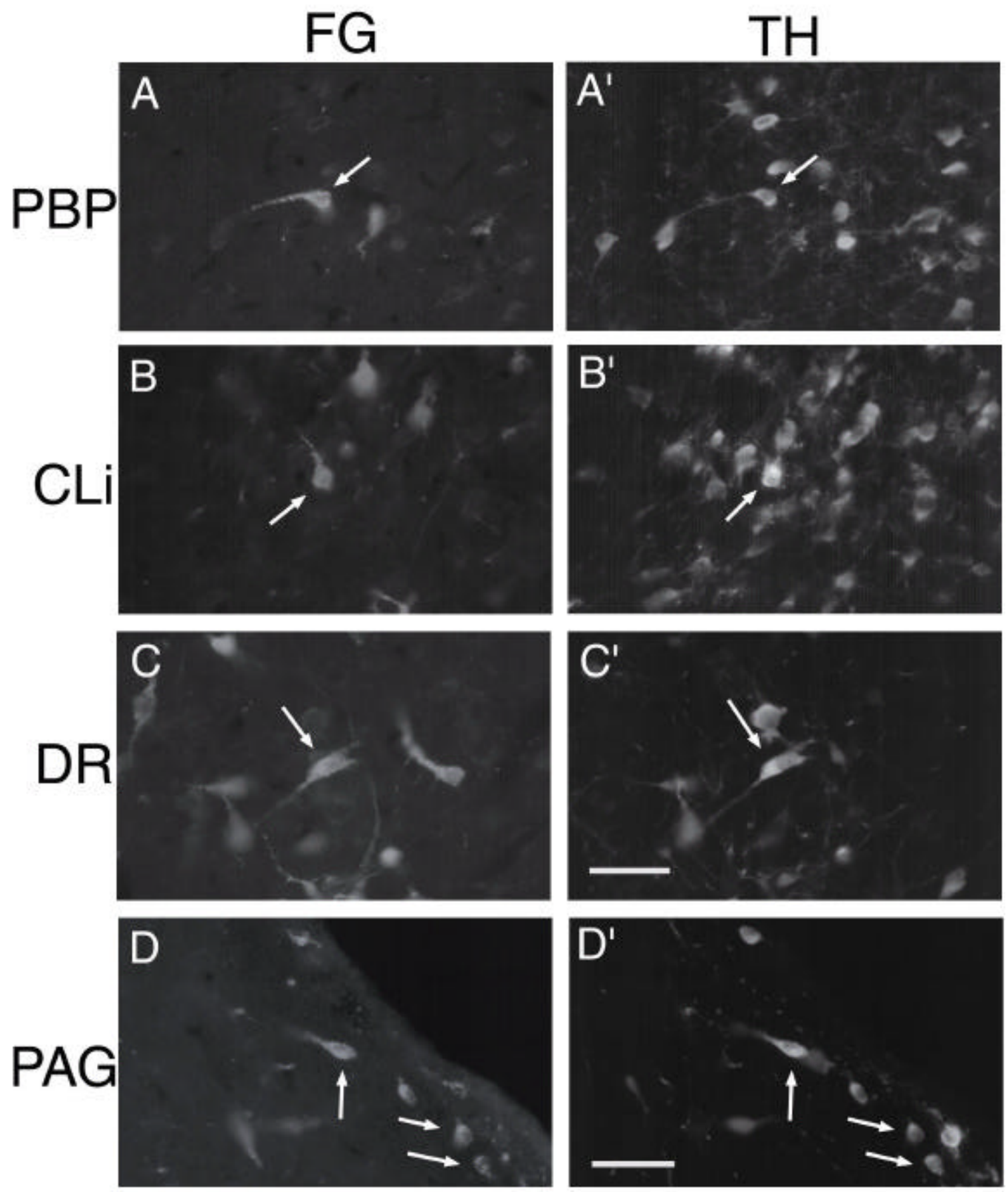

Figura 10: Fotomicrografias de células duplamente marcadas (indicadas pelas setas) presentes nos grupamentos dopaminérgicos do mesencéfalo após injeção de FG no núcleo intersticial lateral da estria terminal. Células contendo FG: coluna æ̀squerda; célu las contendo TH: coluna àdireita. A-A': núcleo parabraquial pigmentoso; B-B': núcleo linear caudal da rafe; C-C': núcleo dorsal da rafe; D-D': substância cinzenta periaquedutal. Barra de escala em C' e D' (válida também para os campos A-D, A' e B') = 50 $\mu \mathrm{m}$. Para abreviaturas, ver lista. 
sendo $17 \%$ no setor dorsolateral do núcleo parabraquial pigmentoso e $16 \%$ no núcleo linear caudal da rafe. A Figura 11 ilustra a contribuição relativa de cada núcleo da área tegmental ventral para a inervação dopaminérgica do núcleo intersticial lateral da estria terminal.

Figura 11: Porcentagem de células* duplamente marcadas encontradas em cada subnúcleo em relação ao total de células duplamente marcadas na área tegmental ventral após injeção de FG no núcleo intersticial lateral da estria terminal.

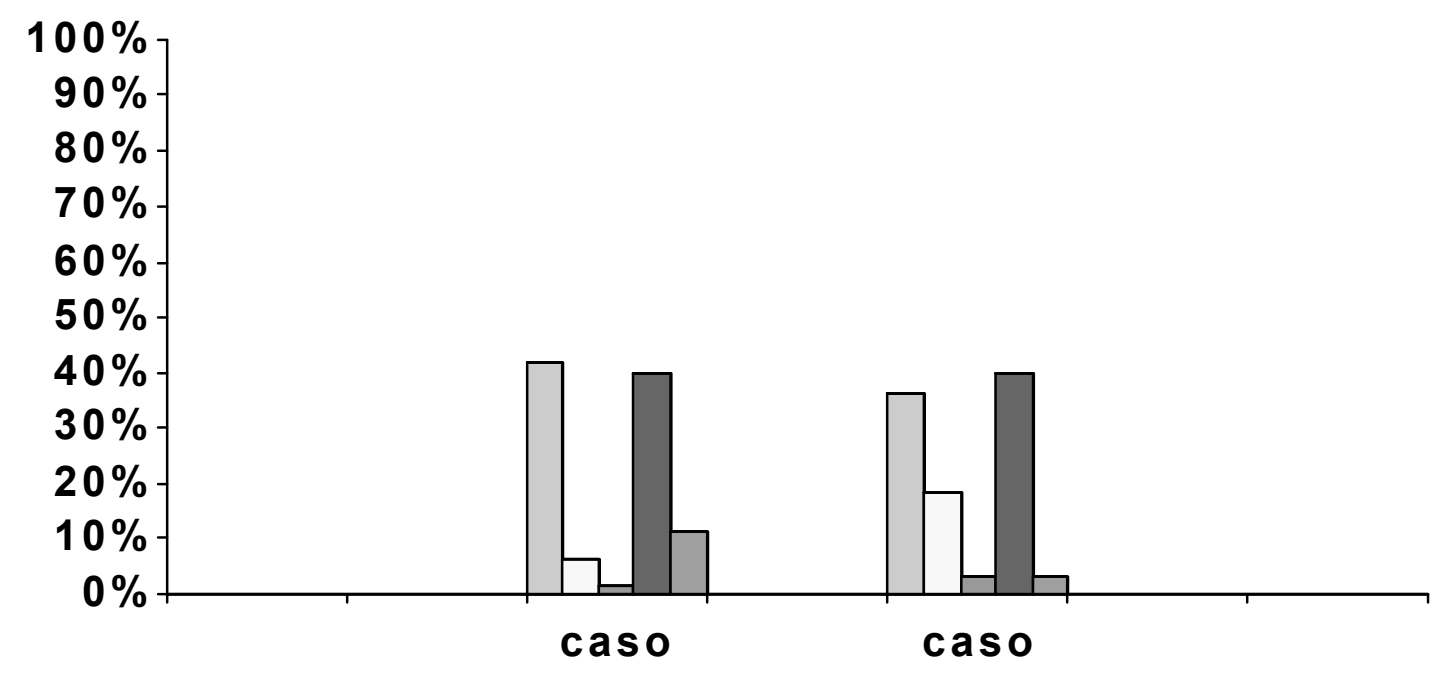

\section{$\square$ PBP $\square$ PN $\square$ RLi $\square$ CLi $\square$ IF}

* as células foram contadas em um compartimento, sendo o intervalo entre os cortes adjacentes de $160 \mu \mathrm{m}$.

\section{Substância Cinzenta Periaquedutal}

A marcação retrógrada na substância cinzenta periaquedutal é densa nas colunas lateral e ventrolateral, principalmente nos níveis de $7,0 \mathrm{~mm}$ a $8,3 \mathrm{~mm}$ caudais ao bregma (Fig. 12). Cerca de um terço das células FG-ir observadas neste território são também TH-ir. As células do grupamento A10dc da substância cinzenta periaquedutal representam cerca de $35 \%$ do número de células duplamente marcadas observadas no caso 240 (Figs. 13 e 10; Tabela 8). 
Tabela 8: Porcentagem de células* duplamente marcadas encontradas na substância cinzenta central e no núcleo dorsal da rafe em relação ao total visto por caso com injeção no núcleo intersticial lateral da estria terminal.

\begin{tabular}{c|cc}
\hline caso & 240 & 243 \\
\hline A11/SCPV & $0.5 \%$ & $1.4 \%$ \\
A10dc/PAG & $34.4 \%$ & $67.4 \%$ \\
A10dc/DR & $9 \%$ & $11.4 \%$ \\
\hline
\end{tabular}

${ }^{*}$ as células foram contadas em um compartimento, sendo o intervalo entre os cortes adjacentes de $160 \mu \mathrm{m}$.

Núcleo Dorsal da Rafe

As células retrogradamente marcadas são numerosas especialmente nos setores dorsais e rostrais do núcleo dorsal da rafe (Fig. 12), sendo quase $35 \%$ destas células duplamente marcadas. O grupamento A10dc do núcleo dorsal da rafe contribui com quase $10 \%$ de todas as células duplamente marcadas encontradas no caso 240 (Fig. 13;Tabela 8). 


\subsection{CASOS COM INJEÇÃO AMÍGDALA EXPANDIDA SUBLENTICULAR}

De nove animais que receberam injeção de FG tendo como alvo a divisão central da amígdala expandida sublenticular, quatro (casos 323, 332, 333 e 334) envolviam este núcleo, sendo a injeção do caso 323 a mais dorsal, e a do caso 333 a mais ventral (Figura 3). O depósito de FG abarcou principalmente a divisão central da amígdala expandida nos casos 332 e 334, e tanto a divisão central quanto a medial no caso 333. Nos casos 332, 333 e 334 houve certo envolvimento do globo pálido adjacente, sendo este mais apreciável no caso 332. Já no caso 323, o depósito de FG estava centrado na porção ventral do globo pálido, envolvendo em menor grau a divisão central da amígdala expandida sublenticular, e este caso foi usado como controle.

A distribuição das células retrogradamente e duplamente marcadas (Figura 12; Tabelas 9 e 10) e a contribuição relativa de cada grupamento dopaminérgico para a inervação da amígdala expandida sublenticular (Figura 13) é semelhante nos casos 332,333 e 334 . O caso 334 foi escolhido como representativo e será descrito em detalhes.

A amígdala expandida sublenticular recebe inervação dopaminérgica predominantemente dos grupamentos mesencefálicos ventrais ipsolaterais (A8, A9 e A10), sendo pouco expressiva a contribuição do núcleo dorsal da rafe e da substância cinzenta periaquedutal (grupamento A10dc), bem como dos grupamentos dopaminérgicos diencefálicos.

\section{Diencéfalo}

Um número pequeno de células FG-ir foi encontrado nos núcleos arqueado e periventricular do hipotálamo e na zona incerta medial (Tabela 9). 


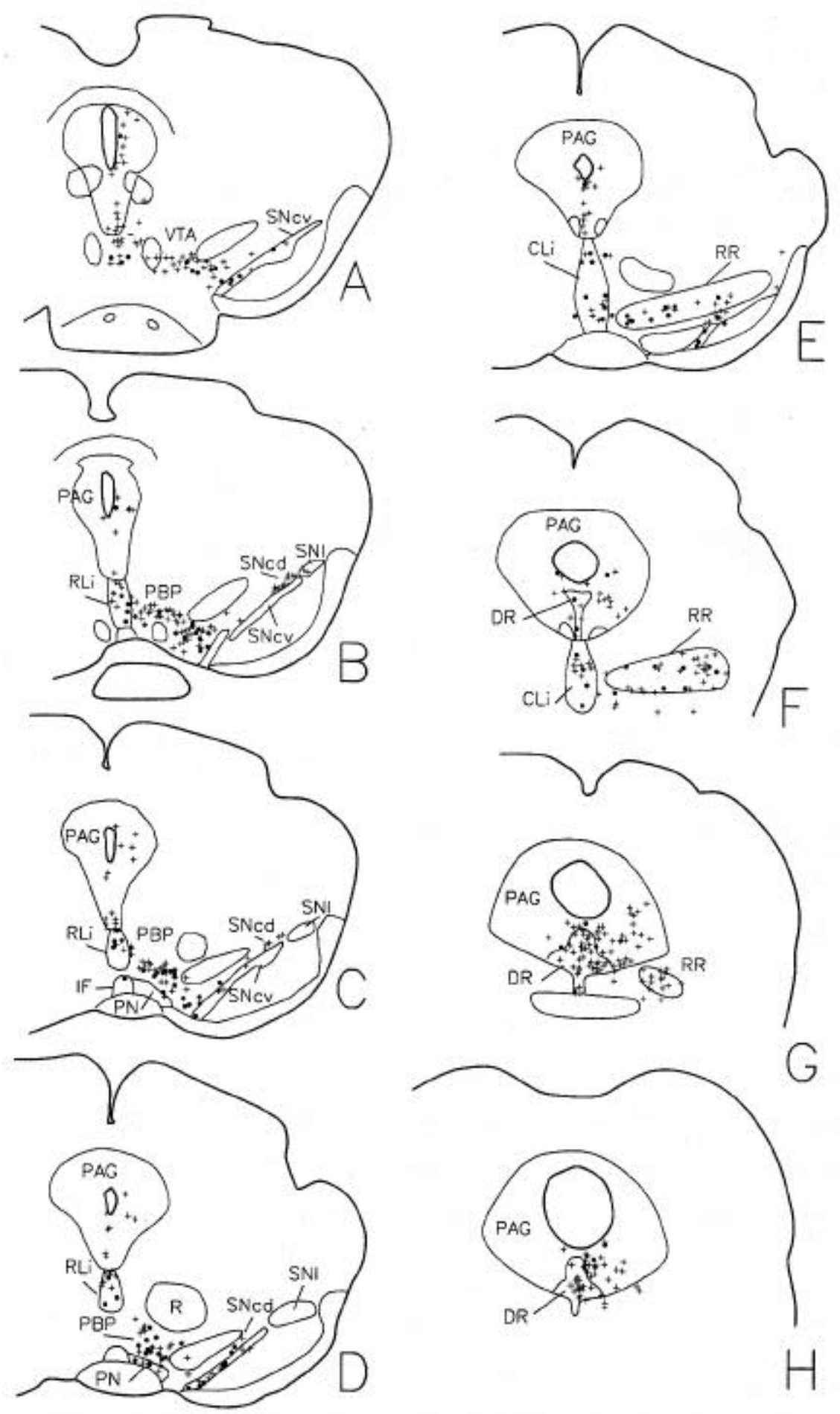

Figura 12: Representação esquemática da distribuição das células contendo FG (cruzes) e FG e TH (pontos) no caso 334, com injeção na amígdala expandida sublenticular. Cada símbolo representa uma célula. Para abreviaturas, ver lista. 
Figura 13: Porcentagem de células* duplamente marcadas encontradas em cada grupamento dopaminérgico em relação ao total visto por caso com injeção de FG na amígdala expandida sublenticular.

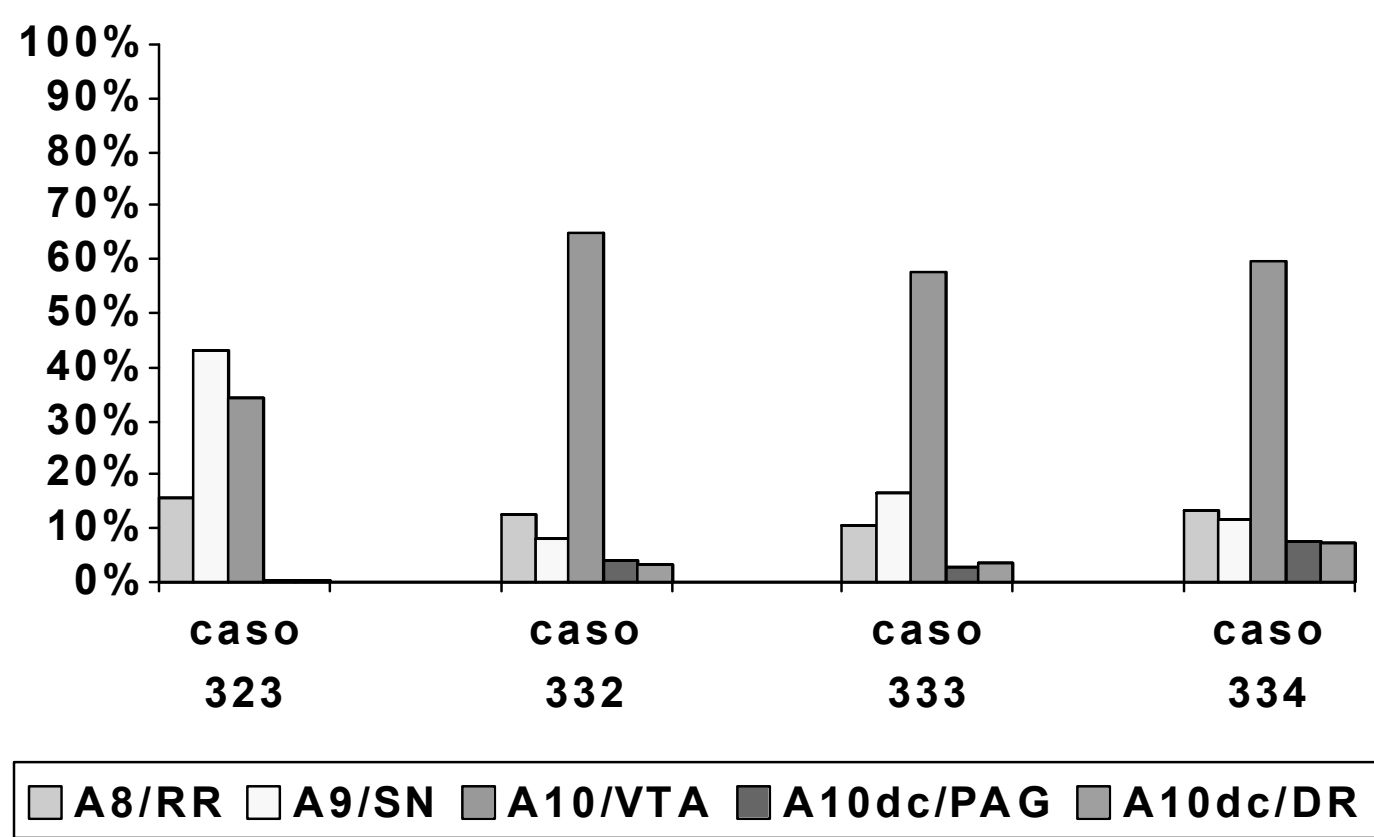

* as células foram contadas em um compartimento, sendo o intervalo entre os cortes adjacentes de $160 \mu \mathrm{m}$.

A marcação retrógrada é densa na região posterior do tálamo ao longo da linha média, i.e., nos núcleos paraventricular posterior, intermédio dorsal, posteromediano, central medial, porção medial do núcleo parafascicular, e porção magnocelular do núcleo subparafascicular. Esta marcação se continua caudalmente com a marcação observada na substância cinzenta periventricular.

No caso 334, foram observadas umas poucas células duplamente marcadas no grupo A11, tanto no tálamo, quanto na substância cinzenta periventricular (Tabela 10). Nenhuma célula duplamente marcada foi vista nos grupamentos diencefálicos A12, A13 e A14. À semelhança do caso 334, em outros casos com injeção de FG na 
amígdala expandida sublenticular, apenas ocasionalmente foram vistas células FG-ir e TH-ir nos grupos A13 e A14.

Tabela 9: Número* de células contendo FG observadas nos núcleos correspondentes aos grupamentos dopaminérgicos mesodiencefálicos após injeção de FG na amígdala expandida sublenticular.

\begin{tabular}{|c|c|c|c|c|c|}
\hline \multicolumn{2}{|c|}{ caso } & \multirow{2}{*}{$\begin{array}{c}323 \\
122\end{array}$} & \multirow{2}{*}{$\begin{array}{l}332 \\
150\end{array}$} & \multirow{2}{*}{$\begin{array}{l}333 \\
319\end{array}$} & \multirow{2}{*}{$\begin{array}{l}334 \\
227\end{array}$} \\
\hline A8 & $\mathrm{RR}$ & & & & \\
\hline \multirow[t]{3}{*}{ A9 } & SNcd & 114 & 27 & 143 & 84 \\
\hline & SNcv & 117 & 26 & 40 & 42 \\
\hline & SNI & 0 & 1 & 23 & 11 \\
\hline \multirow[t]{5}{*}{ A10 } & PBP & 212 & 354 & 391 & 299 \\
\hline & PN & 0 & 8 & 19 & 13 \\
\hline & RLi & 50 & 146 & 153 & 106 \\
\hline & CLi & 29 & 71 & 95 & 86 \\
\hline & IF & 1 & 5 & 8 & 2 \\
\hline \multicolumn{2}{|c|}{ A8/A9/A10 } & 29 & 26 & 69 & 0 \\
\hline A10dc & PAG & 83 & 215 & 458 & 263 \\
\hline A10dc & DR & 157 & 283 & 354 & 245 \\
\hline A11 & SCPV & 64 & 45 & 88 & 114 \\
\hline A12 & Arq & $-* *$ & 1 & 30 & 29 \\
\hline A13 & ZIm & - & 11 & 48 & 42 \\
\hline A14 & $\mathrm{PVH}$ & - & 9 & 11 & 17 \\
\hline \multicolumn{2}{|c|}{ TOTAL } & 978 & 1378 & 2249 & 1580 \\
\hline
\end{tabular}

${ }^{*}$ as células foram contadas em um compartimento, sendo o intervalo entre os cortes adjacentes de $160 \mu \mathrm{m}$.

** Nos campos marcados com o símbolo (-) não foi realizada a análise quantitativa.

\section{Mesencéfalo}

Numerosas células retrogradamente marcadas foram observadas no campo retrorrubral, na substância negra, na área tegmental ventral, na substância cinzenta periaquedutal e no núcleo dorsal da rafe (Tabela 9). Contudo, 85\% das células 
duplamente marcadas estão concentradas nos grupamentos mesencefálicos ventrais, e apenas $15 \%$ estão situadas no grupamento A10dc (Figura 12).

Tabela 10: Número* de células contendo FG e TH encontradas nos grupamentos dopaminérgicos mesodiencefálicos após injeção de FG na amígdala expandida sublenticular.

\begin{tabular}{|c|c|c|c|c|c|}
\hline \multicolumn{2}{|c|}{ caso } & 323 & 332 & 333 & 334 \\
\hline A8 & $\mathrm{RR}$ & 68 & 31 & 59 & 47 \\
\hline \multirow[t]{3}{*}{ A9 } & SNcd & 77 & 1 & 57 & 8 \\
\hline & SNcv & 100 & 19 & 31 & 32 \\
\hline & SNI & 0 & 0 & 1 & 0 \\
\hline \multirow[t]{5}{*}{ A10 } & PBP & 127 & 101 & 239 & 128 \\
\hline & PN & 0 & 0 & 9 & 7 \\
\hline & RLi & 10 & 29 & 40 & 29 \\
\hline & CLi & 9 & 30 & 33 & 45 \\
\hline & IF & 0 & 0 & 4 & 2 \\
\hline \multicolumn{2}{|c|}{$\mathrm{A} 8 / \mathrm{A} 9 / \mathrm{A} 10$} & 24 & 15 & 32 & 0 \\
\hline $\mathrm{A} 10 \mathrm{dc}$ & PAG & 2 & 10 & 15 & 27 \\
\hline $\mathrm{A} 10 \mathrm{dc}$ & DR & 2 & 8 & 20 & 25 \\
\hline A11 & SCPV & 1 & 0 & 3 & 2 \\
\hline A12 & Arq & $-* *$ & 0 & 0 & 0 \\
\hline A13 & ZIm & - & 0 & 2 & 0 \\
\hline A14 & PVH & - & 0 & 3 & 0 \\
\hline \multicolumn{2}{|c|}{ TOTAL } & 420 & 244 & 548 & 352 \\
\hline
\end{tabular}

${ }^{\star}$ as células foram contadas em um compartimento, sendo o intervalo entre os cortes adjacentes $\mathrm{de}$ $160 \mu \mathrm{m}$.

** Nos campos marcados com o símbolo (-) não foi realizada a análise quantitativa.

Campo retrorrubral

O campo retrorrubral possui uma densa marcação retrógrada ao longo de toda a sua extensão. No caso 334 , aproximadamente $20 \%$ destas células são 


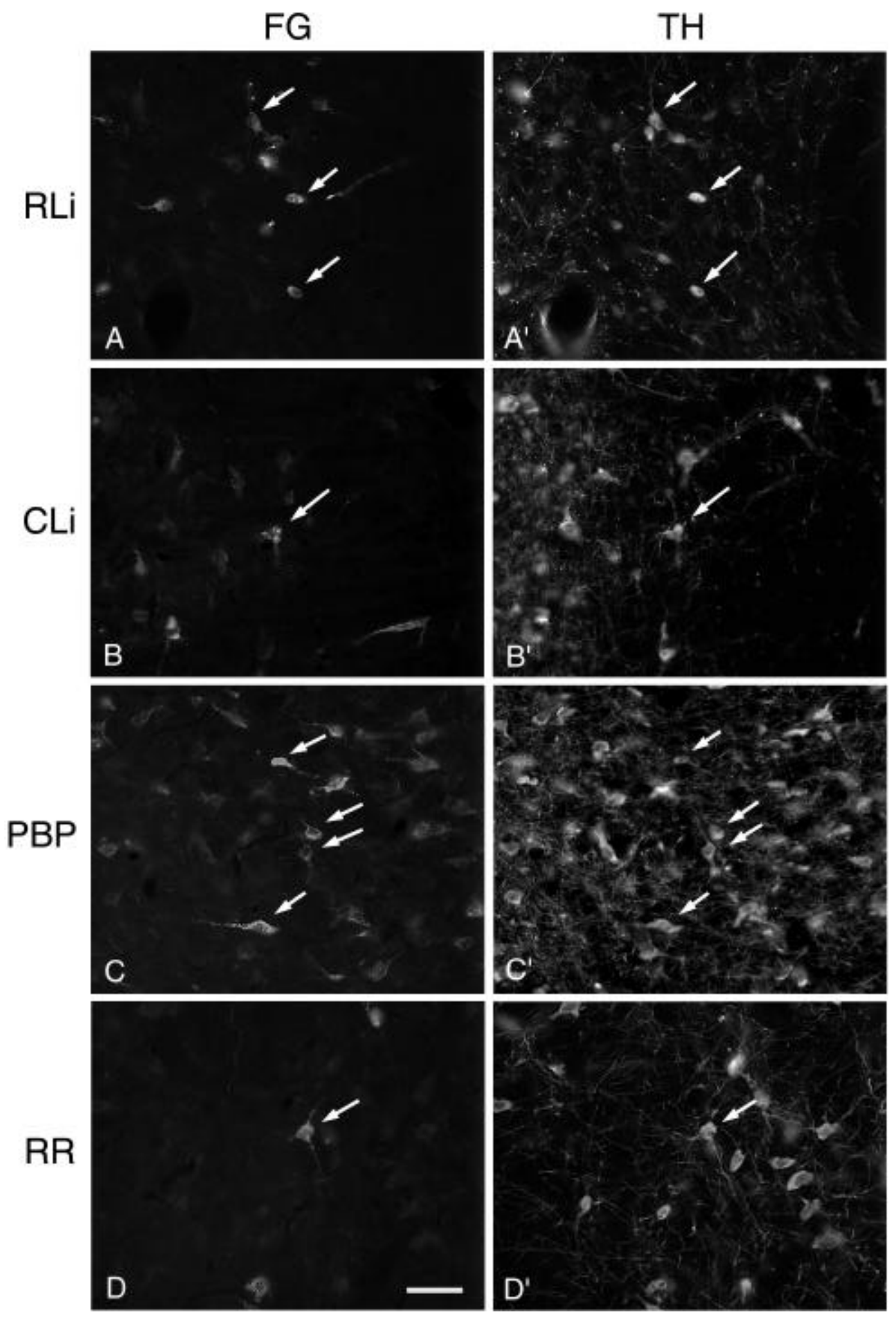

Figura 14: Fotomicrografias de células duplamente marcadas (indicadas pelas setas) presentes nos grupamentos dopaminérgicos ventrais após injeção de FG na amígdala expandida sublenticular. Células contendo FG: coluna æ̀squerda; células contendo TH: col una àdireita. A - $A$ ': núcleo linear rostral da rafe; B-B': núcleo linear caudal da rafe; C-C': núcleo parabraquial pigmentoso; D-D': campo retrorrubral. Barra de escala em D (válida também para os demais campos) $=50 \mu \mathrm{m}$. Para abreviaturas, ver lista. 
duplamente marcadas, e representam pouco mais de $10 \%$ da inervação dopaminérgica da amígdala expandida sublenticular (Figuras 12 e 13,Tabelas 9 -11). Substância negra

As células FG-ir vistas na substância negra, pars compacta, estão localizadas principalmente na sua porção dorsal e, em menor grau, na sua porção ventral (Figura 12; Tabela 9). O grupamento A9 possui ao redor de $10 \%$ do total de células duplamente marcadas encontradas no caso 334, sendo que a maioria delas está na sua parte compacta ventral (Figura 13; Tabelas 10 e 11). Um número bem menor de células retrogradamente marcadas foi visto na substância negra, pars lateralis, e nenhuma delas é duplamente marcada (Figura 12; Tabelas 9 e 10).

Tabela 11: Porcentagem de células* duplamente marcadas encontradas em cada grupamento dopaminérgico do mesencéfalo ventral em relação ao total visto por caso com injeção de FG na amígdala expandida sublenticular.

\begin{tabular}{c|cccc}
\hline caso & 323 & 332 & 333 & 334 \\
\hline A8/RR & $16 \%$ & $12,6 \%$ & $10,5 \%$ & $13,2 \%$ \\
A9/SN & $43,2 \%$ & $8,1 \%$ & $16,5 \%$ & $11,6 \%$ \\
A10/VTA & $34,1 \%$ & $65 \%$ & $57,7 \%$ & $59,6 \%$ \\
\hline
\end{tabular}

${ }^{*}$ as células foram contadas em um compartimento, sendo o intervalo entre os cortes adjacentes de $160 \mu \mathrm{m}$.

\section{Área Tegmental Ventral}

$\mathrm{Na}$ área tegmental ventral, a marcação retrógrada é abundante no núcleo parabraquial pigmentoso, de densidade moderada nos núcleos linear rostral e caudal da rafe, e bem modesta nos núcleos paranigral e interfascicular (Figura 12; Tabela 9).

Cerca de $40 \%$ das células FG-ir vistas na área tegmental ventral são também TH-ir, somando por volta de $60 \%$ do total de células duplamente marcadas presentes neste caso. A maioria delas está no núcleo parabraquial pigmentoso, mais 
concentradas em sua porção lateral (Figura 12), e representam pouco mais de $30 \%$ da inervação dopaminérgica da amígdala expandida sublenticular (Figura 13; Tabelas 10 e 11). Os núcleos linear rostral e caudal da rafe possuem juntos cerca de $20 \%$ das células duplamente marcadas deste caso (Tabela 10), homogeneamente distribuídas por toda sua extensão (Figura 12). Poucas células duplamente marcadas foram vistas nos núcleos paranigral e interfascicular, somando menos de $5 \%$ do total encontrado no caso. A Figura 15 ilustra a distribuição relativa das células duplamente marcadas vistas nos núcleos da área tegmental ventral.

Figura 15: Porcentagem de células* duplamente marcadas em cada subnúcleo em relação ao total de células duplamente marcadas na área tegmental ventral após injeção de FG na amígdala expandida sublenticular.

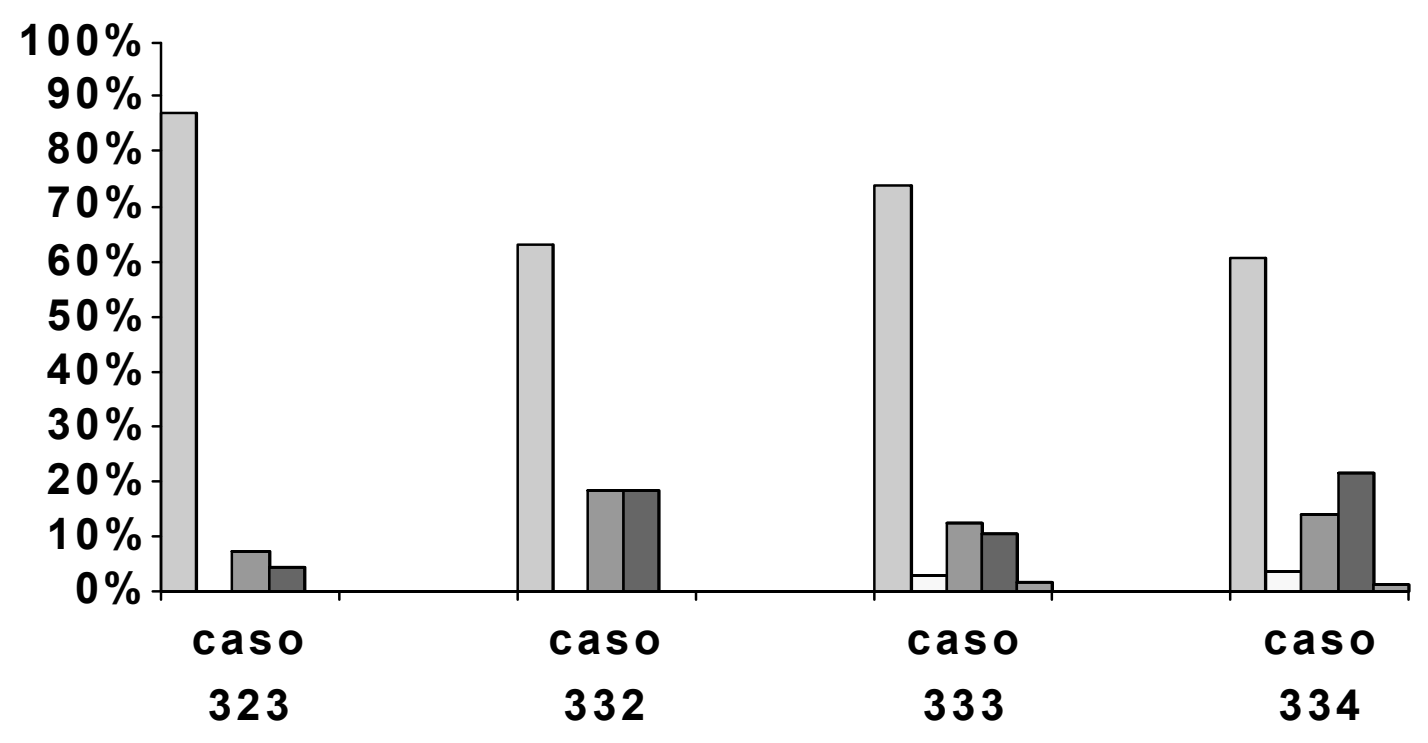

\section{$\square$ PBP $\square$ PN $\square$ RLi $\square$ CLi $\square$ IF}

* as células foram contadas em um compartimento, sendo o intervalo entre os cortes adjacentes de $160 \mu \mathrm{m}$.

Substância Cinzenta Periaquedutal 
Uma densa marcação retrógrada foi observada em níveis caudais da substância cinzenta periaquedutal lateral e ventrolateral, onde estão também localizadas 7\% das células duplamente marcadas vistas neste caso (Figuras $12 \mathrm{e}$ 13; Tabelas 9, 10 e 12).

Núcleo Dorsal da Rafe

Um grande número de células FG-ir está localizado no núcleo dorsal da rafe, principalmente em níveis rostrocaudais intermédios (Figura 12; Tabela 9). Dentre estas células, poucas são também TH-ir (Tabela 10). O grupamento A10dc do núcleo dorsal da rafe contribui com aproximadamente $7 \%$ do total de células duplamente marcadas encontradas no caso 334 (Figura 13; Tabela 12).

Tabela 12: Porcentagem de células* duplamente marcadas encontradas na substância cinzenta central e no núcleo dorsal da rafe em relação ao total visto por caso com injeção de FG na amígdala expandida sublenticular.

\begin{tabular}{c|cccc}
\hline caso & 323 & 332 & 333 & 334 \\
\hline A11/SCPV & $\mathbf{0 , 2} \%$ & $\mathbf{0}$ & $\mathbf{0 , 5 \%}$ & $\mathbf{0 , 5 \%}$ \\
A10dc/PAG & $\mathbf{0 , 4} \%$ & $\mathbf{4} \%$ & $\mathbf{2 , 6 \%}$ & $\mathbf{7 , 6 \%}$ \\
A10dc/DR & $\mathbf{0 , 4 \%}$ & $\mathbf{3 , 2} \%$ & $\mathbf{3 , 5 \%}$ & $\mathbf{7 \%}$ \\
\hline
\end{tabular}

$\bar{*}$ as células foram contadas em um compartimento, sendo o intervalo entre os cortes adjacentes $d e$ $160 \mu \mathrm{m}$.

\section{CASO CONTROLE}

No caso 323, a injeção de $F G$ acometeu principalmente a porção ventral do globo pálido, e em menor grau, a divisão central da amígdala expandida sublenticular.

Numerosas células retrogradamente marcadas foram vistas na porção ventral da substância negra, pars compacta, sendo que $85 \%$ delas eram duplamente marcadas. Assim, à diferença dos demais casos desta série, o grupamento A9 é o 
que mais contribui para a inervação dopaminérgica da porção ventral do globo pálido, possuindo pouco mais de $40 \%$ de todas as células FG-ir e TH-ir vistas neste caso (Figura 13; Tabelas 9-11). Outra diferença entre este caso e os casos com injeção de FG na amígdala expandida sublenticular é a pequena quantidade de células FG-ir observadas na substância cinzenta periaquedutal (Tabela 9), e conseqüentemente, o pequeno número de células duplamente marcadas visto neste território (Tabelas 10 e 12). 


\subsection{CASOS COM INJEÇÃO NO NÚCLEO INTERSTICIAL DO RAMO POSTERIOR DA COMISSURA ANTERIOR}

Foram obtidos dois casos com depósito de FG centrados no núcleo intersticial do ramo posterior da comissura anterior (casos 266 e 268), que envolvem tanto a divisão medial quanto a divisão lateral deste núcleo. No caso 266, o depósito de FG acomete também a porção dorsal da área amigdalóide anterior e o pálido ventral, e no caso 268, apenas o pálido ventral (Fig. 3).

A distribuição das células retrogradamente e duplamente marcadas (Fig. 16; Tabelas 13 e 14), e a contribuição relativa de cada grupamento dopaminérgico para a inervação do núcleo intersticial do ramo posterior da comissura anterior (Fig. 17) são semelhantes em ambos os casos. O caso 268 foi escolhido como representativo e será descrito em detalhes.

Assim como no caso com injeção de FG na amígdala expandida sublenticular, a inervação dopaminérgica do núcleo intersticial do ramo posterior da comissura anterior se origina quase exclusivamente dos grupamentos mesencefálicos ventrais ipsolaterais, e a contribuição do grupamento dopaminérgico A10dc do núcleo dorsal da rafe e substância cinzenta periaquedutal é mínima. Os grupamentos dopaminérgicos do diencéfalo ( $A 11, A 12, A 13$ e $A 14)$ não contribuem para a inervação do núcleo intersticial do ramo posterior da comissura anterior.

\section{Diencéfalo}

Muito poucas células retrogradamente marcadas foram vistas no núcleo periventricular do hipotálamo e na zona incerta medial, e nenhuma foi detectada no núcleo arqueado no caso 268 (Tabela 13). 

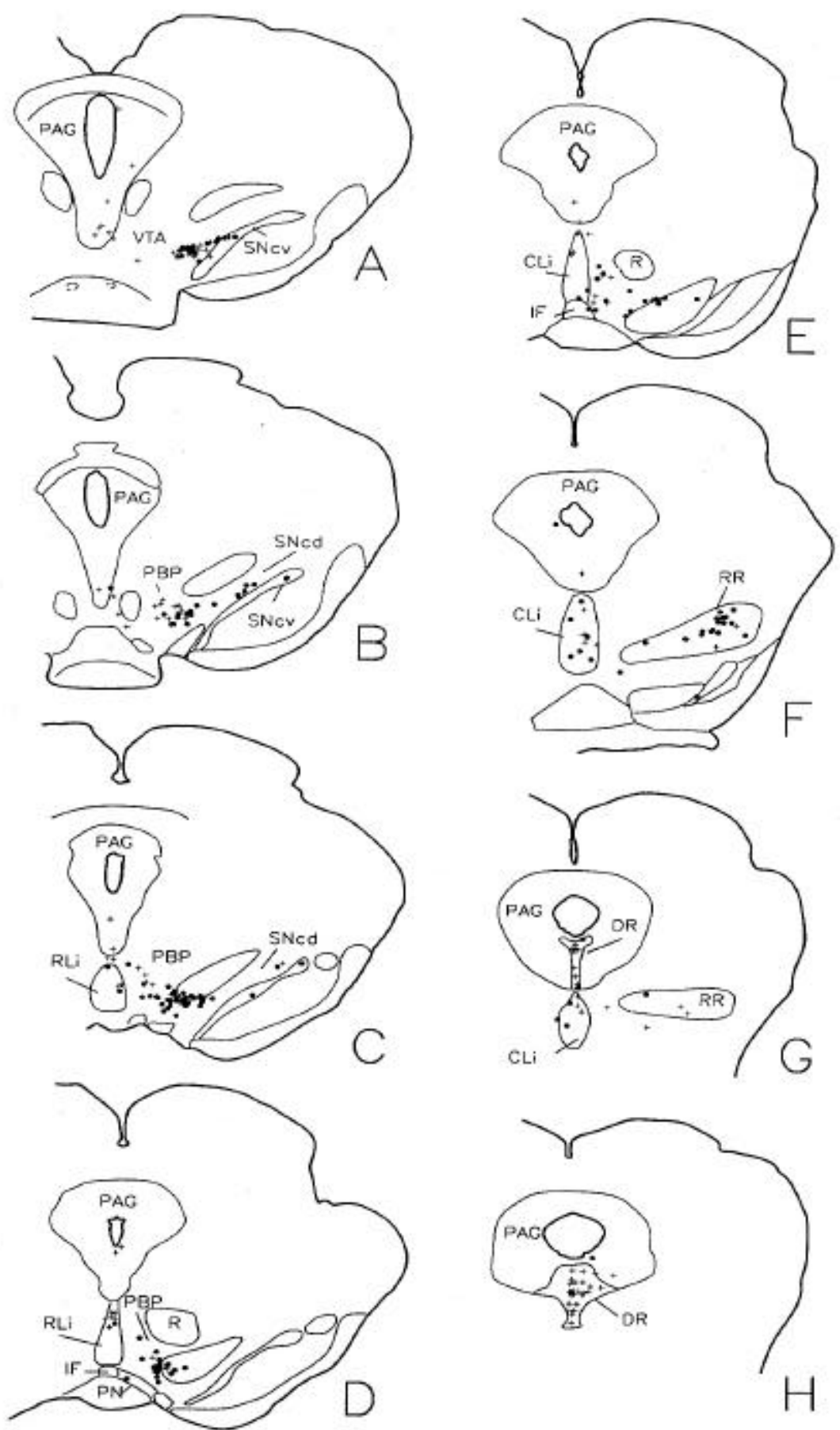

Figura 16: Representação esquemática da distribuição das células contendo FG (cruzes) e FG e TH (pontos) no caso 268, com injeção no núcleo intersticial do ramo posterior da comissura anterior. Cada símbolo representa uma célula. Para abreviaturas, ver lista. 
Figura 17: Porcentagem de células* duplamente marcadas encontradas em cada grupamento dopaminérgico em relação ao total visto por caso com injeção de FG no núcleo intersticial do ramo posterior da comissura anterior.

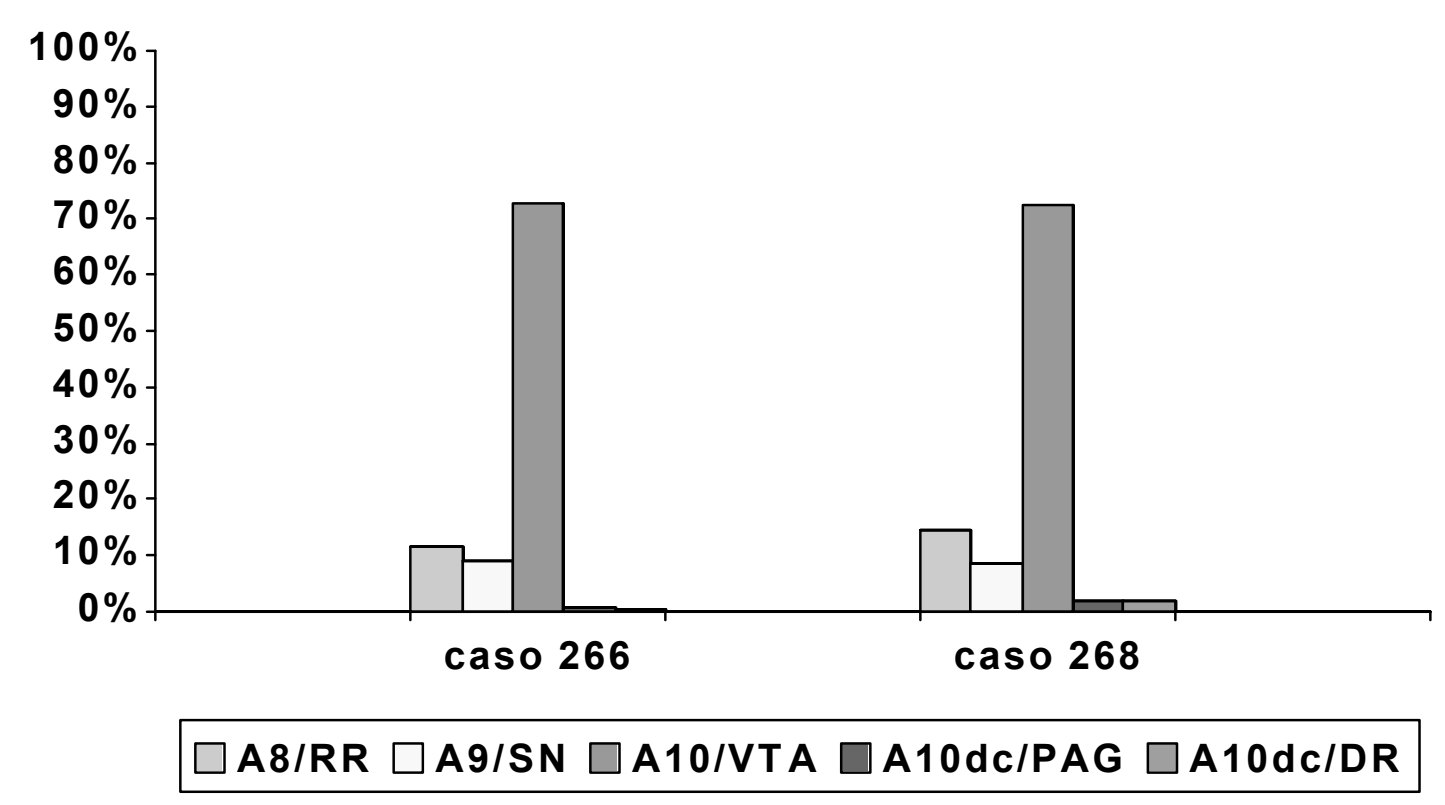

* as células foram contadas em um compartimento, sendo o intervalo entre os cortes adjacentes de $160 \mu \mathrm{m}$.

A marcação retrógrada é moderada nos núcleos paraventricular posterior, intermédio dorsal, posteromediano, central medial e porção medial do núcleo parafascicular no tálamo posterior. Assim como nos casos com injeção nos outros componentes da amígdala expandida central, esta marcação se estende até a substância cinzenta periventricular, onde coincide de forma mais evidente com o grupamento A11.

Não foram vistas células duplamente marcadas nos grupamentos dopaminérgicos do diencéfalo e nem tampouco na substância cinzenta periventricular (Tabela 14). 


\section{Mesencéfalo}

Os grupamentos do mesencéfalo ventral constituem a grande fonte de inervação dopaminérgica do núcleo intersticial do ramo posterior da comissura anterior, possuindo aproximadamente $95 \%$ de todas as células duplamente marcadas observadas no caso 268 (Tabelas 14 e 15).

Tabela 13: Número* de células contendo FG observadas nos núcleos correspondentes aos grupamentos dopaminérgicos mesodiencefálicos após injeção de FG no núcleo intersticial do ramo posterior da comissura anterior.

\begin{tabular}{cc|cc}
\hline \multicolumn{2}{c|}{ caso } & 266 & 268 \\
\hline A8 & RR & $\mathbf{5 6}$ & $\mathbf{6 5}$ \\
A9 & SNcd & 29 & $\mathbf{3 4}$ \\
& SNcv & $\mathbf{1 1}$ & $\mathbf{4}$ \\
& SNI & $\mathbf{1}$ & $\mathbf{0}$ \\
A10 & PBP & $\mathbf{2 1 0}$ & $\mathbf{2 5 1}$ \\
& PN & $\mathbf{8}$ & $\mathbf{5}$ \\
& Rli & $\mathbf{6 0}$ & $\mathbf{4 3}$ \\
& Cli & 39 & $\mathbf{5 2}$ \\
& IF & 3 & $\mathbf{6}$ \\
A8/A9/A10 & 15 & $\mathbf{2}$ \\
A10dc & PAG & 24 & 33 \\
A10dc & DR & 142 & $\mathbf{1 1 0}$ \\
A11 & SCPV & $\mathbf{2 5}$ & $\mathbf{0}$ \\
A12 & Arq & $\mathbf{1}$ & $\mathbf{0}$ \\
A13 & Zim & $\mathbf{6}$ & $\mathbf{2}$ \\
A14 & PVH & $\mathbf{4}$ & $\mathbf{2}$ \\
\multicolumn{2}{c}{ TOTAL } & $\mathbf{6 3 4}$ & $\mathbf{6 0 9}$ \\
\hline
\end{tabular}

* as células foram contadas em um compartimento, sendo o intervalo entre os cortes adjacentes de $160 \mu \mathrm{m}$. 
Campo retrorrubral

A marcação retrógrada no campo retrorrubral é moderada e está distribuída por toda sua extensão rostrocaudal (Fig. 16). As células duplamente marcadas do campo retrorrubral representam quase $15 \%$ da inervação dopaminérgica do núcleo intersticial do ramo posterior da comissura anterior (Fig. 17 e 18; Tabela 15).

Tabela 14: Número* de células contendo FG e TH encontradas nos grupamentos dopaminérgicos mesodiencefálicos após injeção de FG no núcleo intersticial do ramo posterior da comissura anterior.

\begin{tabular}{|c|c|c|c|}
\hline \multicolumn{2}{|c|}{ caso } & \multirow{2}{*}{$\begin{array}{c}266 \\
29\end{array}$} & \multirow{2}{*}{$\begin{array}{c}268 \\
41\end{array}$} \\
\hline A8 & $\mathrm{RR}$ & & \\
\hline \multirow[t]{3}{*}{ A9 } & SNcd & 17 & 20 \\
\hline & $\mathrm{SNcv}$ & 5 & 4 \\
\hline & SNI & 1 & 0 \\
\hline \multirow[t]{5}{*}{ A10 } & PBP & 131 & 150 \\
\hline & PN & 8 & 5 \\
\hline & RLi & 22 & 17 \\
\hline & CLi & 23 & 28 \\
\hline & IF & 0 & 3 \\
\hline \multicolumn{2}{|c|}{ A8/A9/A10 } & 14 & 2 \\
\hline A10dc & PAG & 2 & 5 \\
\hline A10dc & DR & 1 & 5 \\
\hline A11 & SCPV & 0 & 0 \\
\hline A12 & Arq & 0 & 0 \\
\hline A13 & ZIm & 0 & 0 \\
\hline A14 & PVH & 0 & 0 \\
\hline \multicolumn{2}{|c|}{ TOTAL } & 253 & 280 \\
\hline
\end{tabular}

${ }^{*}$ as células foram contadas em um compartimento, sendo o intervalo entre os cortes adjacentes de $160 \mu \mathrm{m}$. 
Substância negra

A substância negra, pars compacta, possui um número moderado de células FG-ir, sendo que a maioria localizada na sua parte dorsal e rostral (Fig. 16; Tabela 13). Destas, cerca de $60 \%$ são duplamente marcadas e representam quase $10 \%$ do total visto neste caso (Fig. 17; Tabela 15). Não foi observada marcação retrógrada na substância negra, pars lateralis.

Tabela 15: Porcentagem de células* duplamente marcadas em cada grupamento dopaminérgico do mesencéfalo ventral em relação ao total visto por caso com injeção de FG no núcleo intersticial do ramo posterior da comissura anterior.

\begin{tabular}{c|cc}
\hline caso & 266 & 268 \\
\hline A8/RR & $11.4 \%$ & $14.6 \%$ \\
A9/SN & $9 \%$ & $8.5 \%$ \\
A10/VTA & $72.7 \%$ & $72.5 \%$ \\
\hline
\end{tabular}

* as células foram contadas em um compartimento, sendo o intervalo entre os cortes adjacentes de $160 \mu \mathrm{m}$.

Área Tegmental Ventral

A marcação retrógrada na área tegmental ventral é densa no núcleo parabraquial pigmentoso, moderada nos núcleos linear rostral e caudal da rafe, e modesta nos núcleos paranigral e interfascicular (Fig. 16; Tabela 13).

Uma fração considerável (56\%) das células retrogradamente marcadas presentes na área tegmental ventral é duplamente marcada, e constituem pouco mais de $70 \%$ do total de células FG-ir e TH-ir observadas neste caso (Tabela 15).

A grande maioria das células duplamente marcadas está no núcleo parabraquial pigmentoso (Fig. 16; Tabela 14), onde tendem a se concentrar em seu setor dorsal. O núcleo parabraquial pigmentoso contém ao redor de $50 \%$ do total de 


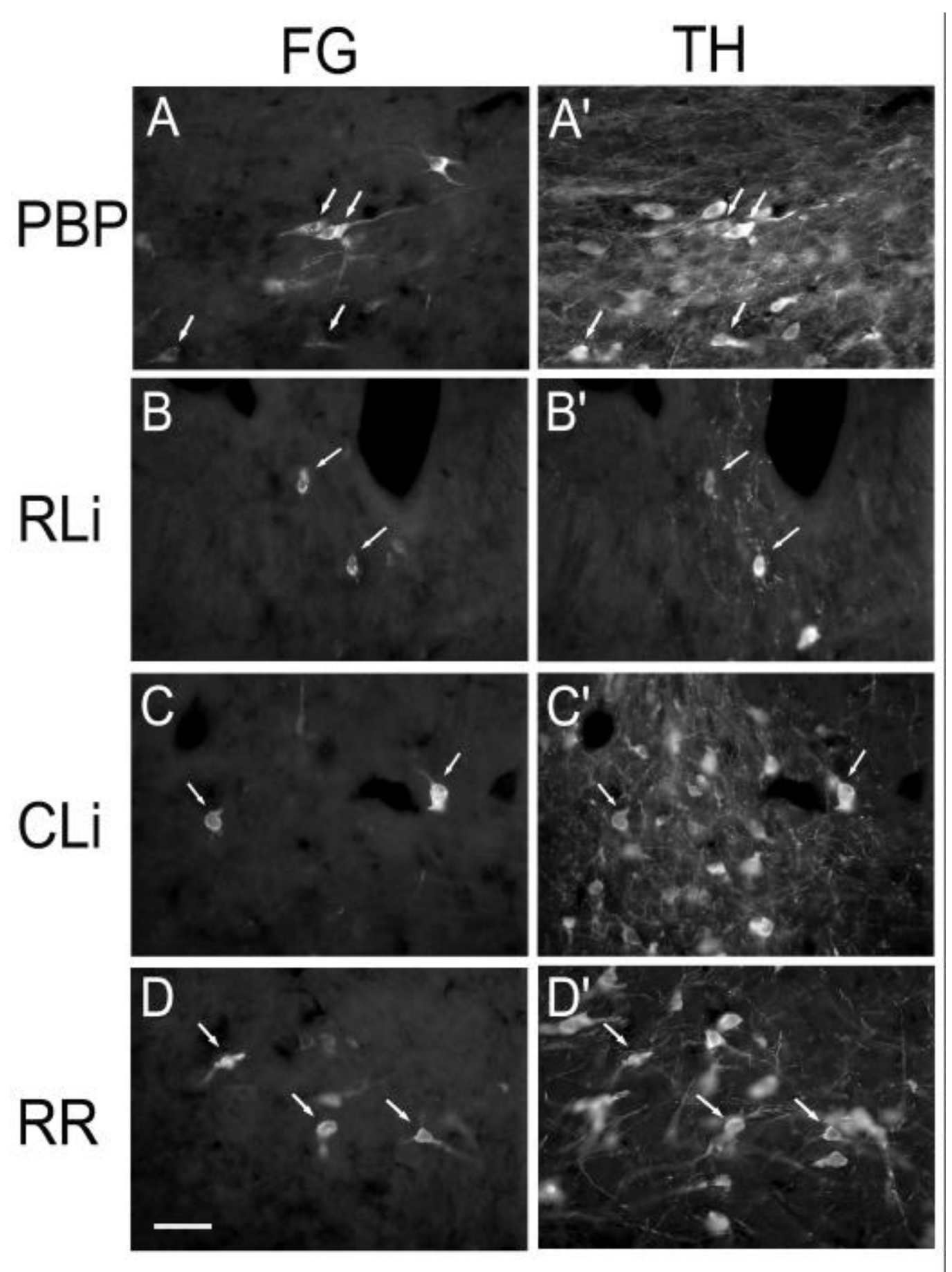

Figura 18: Fotomicrografias de células duplamente marcadas (indicadas pelas setas) presentes nos grupamentos mesencefálicos ventrais após a injeção de FG no núcleo intersticial do ramo posterior da comissura anterior. Células contendo FG: coluna àssquer da; células contendo TH: coluna àdireita. A - $A$ ': núcleo parabraquial pigmentoso; B-B': núcleo linear rostral da rafe; C-C': núcleo linear caudal da rafe; D-D': campo retrorrubral. Barra de escala em $D$ (válida também para os demais campos) $=50 \mu \mathrm{m}$. Para abreviaturas, ver lista. 
células duplamente marcadas encontradas neste caso, e o conjunto dos núcleos linear rostral e caudal da rafe contém pouco mais de 15\%. A Figura 19 ilustra a distribuição relativa das células duplamente marcadas vistas nos núcleos da área tegmental ventral nos dois casos com injeção de FG no núcleo intersticial do ramo posterior da comissura anterior.

Figura 19: Porcentagem de células* duplamente marcadas em cada subnúcleo em relação ao total de células duplamente marcadas na área tegmental ventral após injeção de FG no núcleo intersticial do ramo posterior da comissura anterior.

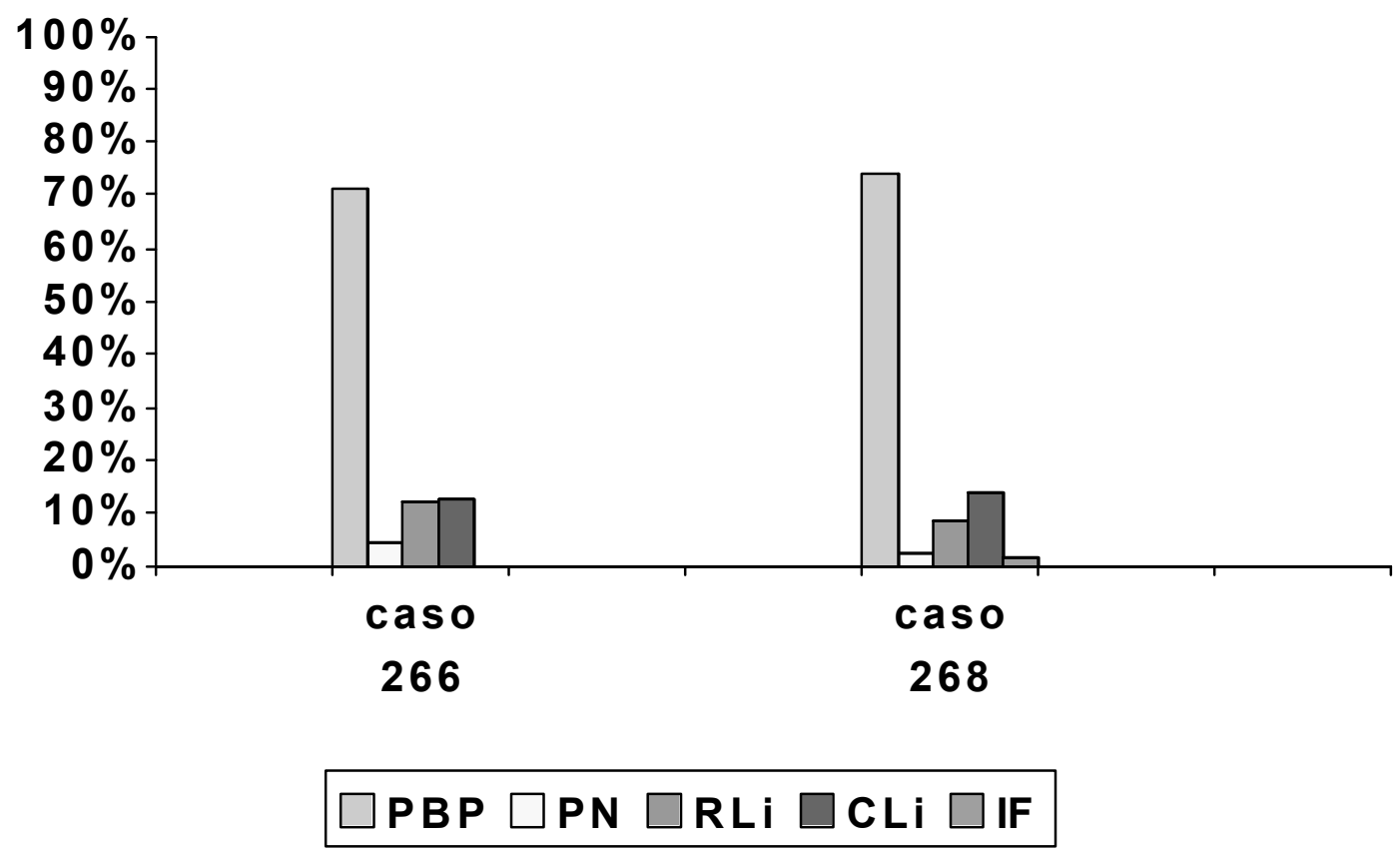

* as células foram contadas em um compartimento, sendo o intervalo entre os cortes adjacentes de $160 \mu \mathrm{m}$.

\section{Substância Cinzenta Periaquedutal}

A marcação retrógrada na substância cinzenta periaquedutal é moderada e mais evidente nos níveis caudais das suas colunas lateral e ventrolateral. Poucas células duplamente marcadas foram vistas na substância cinzenta periaquedutal, representando apenas $2 \%$ do total observado neste caso (Figs. 16 e 17; Tabelas 14 e 16). 
Tabela 16: Porcentagem de células* duplamente marcadas encontradas na substância cinzenta central e do núcleo dorsal da rafe em relação ao total visto por caso com injeção de FG no núcleo intersticial do ramo posterior da comissura anterior.

\begin{tabular}{c|cc}
\hline caso & 266 & 268 \\
\hline A11/SCPV & 0 & 0 \\
A10dc/PAG & $0.8 \%$ & $1.8 \%$ \\
A10dc/DR & $0.4 \%$ & $1.8 \%$ \\
\hline
\end{tabular}

${ }^{*}$ as células foram contadas em um compartimento, sendo o intervalo entre os cortes adjacentes de $160 \mu \mathrm{m}$.

Núcleo Dorsal da Rafe

Um número substancial de células FG-ir foi encontrado no núcleo dorsal da rafe (Tabela 13). Elas estão discretamente mais concentradas no setor dorsal deste núcleo, entretanto, poucas são duplamente marcadas, e correspondem a apenas $2 \%$ do total de células duplamente marcadas encontradas no caso 268 (Figs. 16 e 17; Tabelas 14 e 16). 


\subsection{CASOS COM INJEÇÃO NA CONCHA DO NÚCLEO ACUMBENS}

Foram obtidos cinco casos com injeção de FG em diferentes setores da concha do núcleo acumbens (casos 309, 310, 311, 312 e 318; Fig. 20), sendo a do caso 310 a mais dorsal e a do caso 318 a mais ventral. No caso 310, o depósito de FG abarca a porção caudal, medial e dorsal da concha do núcleo acumbens (também referida como o seu pólo septal). A injeção de FG no caso 312 é bastante semelhante à do caso 310 , mas está localizada um pouco mais ventralmente. Nos casos 309 e 311, a injeção de FG envolve a região rostral e medial da concha do núcleo acumbens, sendo que no caso 309 ela se estende até o pólo rostral deste núcleo. Já no caso 318, o depósito de FG está localizado na região mais ventral da concha do núcleo acumbens e é também mais lateral do que nos demais casos. Em todos estes casos, o depósito de FG envolve perifericamente o cerne do núcleo acumbens. A presença de ocasionais células retrogradamente marcadas na porção ventral da substância negra, pars compacta reforça a pequena contaminação do cerne do núcleo acumbens (Brog et al., 1993; Lynd-Balta e Haber, 1994). Um compartimento adjacente ao local de injeção de cada caso foi processado por imunoperoxidase para substância $P$ a fim de se estabelecer os limites entre o cerne e a concha do núcleo acumbens.

Resultados diferentes foram obtidos nos diversos casos com injeção na concha do núcleo acumbens. Os casos 310 e 318 apresentam padrões distintos entre si no que diz respeito à distribuição e à proporção das células duplamente marcadas vistas em cada grupamento dopaminérgico analisado. Um padrão intermediário ao retratado nestes dois casos foi visto nos casos 309, 311 e 312 (Figs. 21, 22 e 25). 


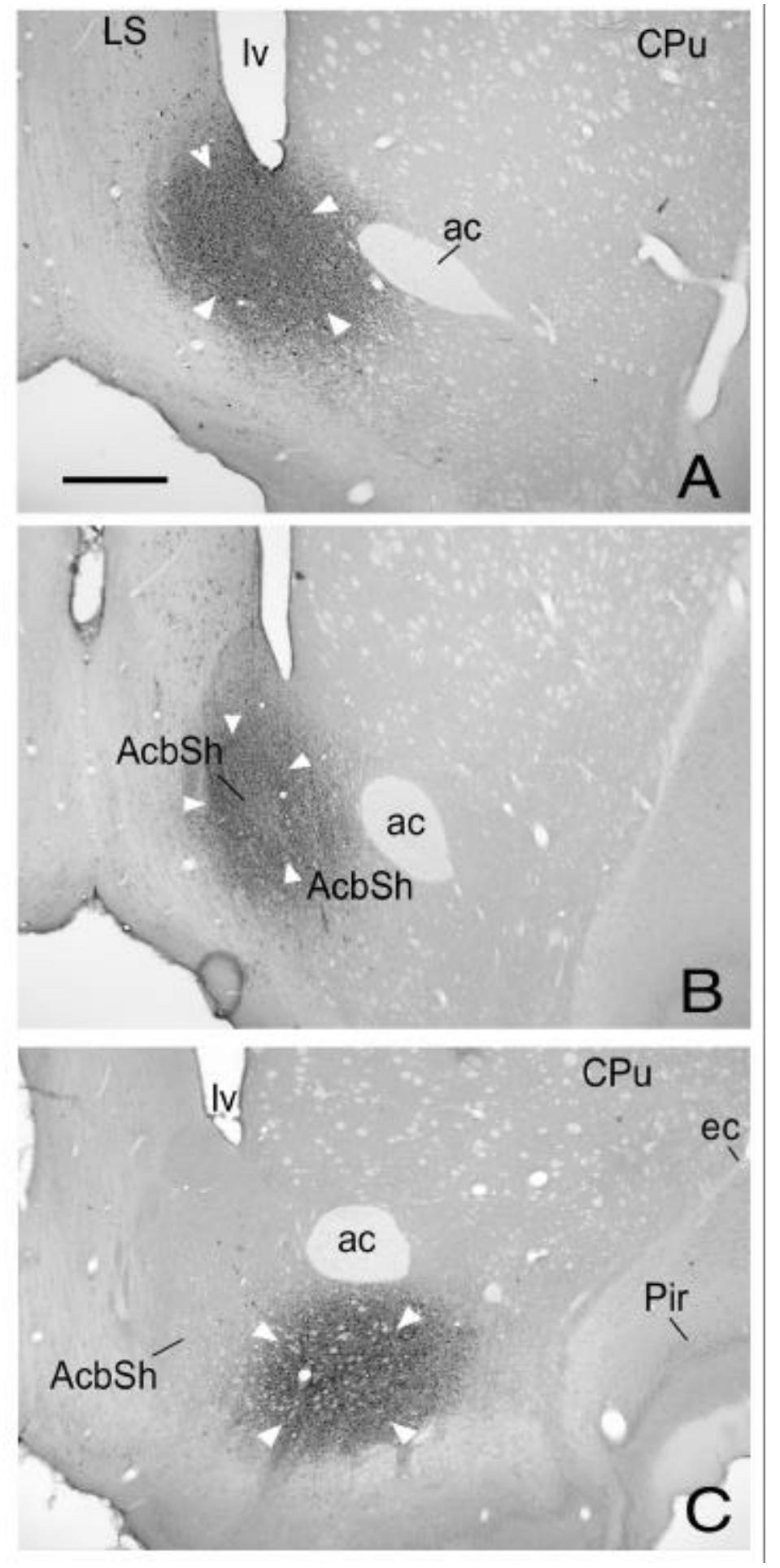

Figura 20: Fotomicrografias de campo claro ilustrando o local de injeção de FG em diversos setores da concha do núcleo acumbens. A: porção caudodorsomedial (caso 310); B: porção intermédia da concha medial (caso 312); C: porção ventral da concha (caso 318). Barra de escala em A (válida também para os demais campos) $=500 \mu \mathrm{m}$. Para abreviaturas, ver lista. 

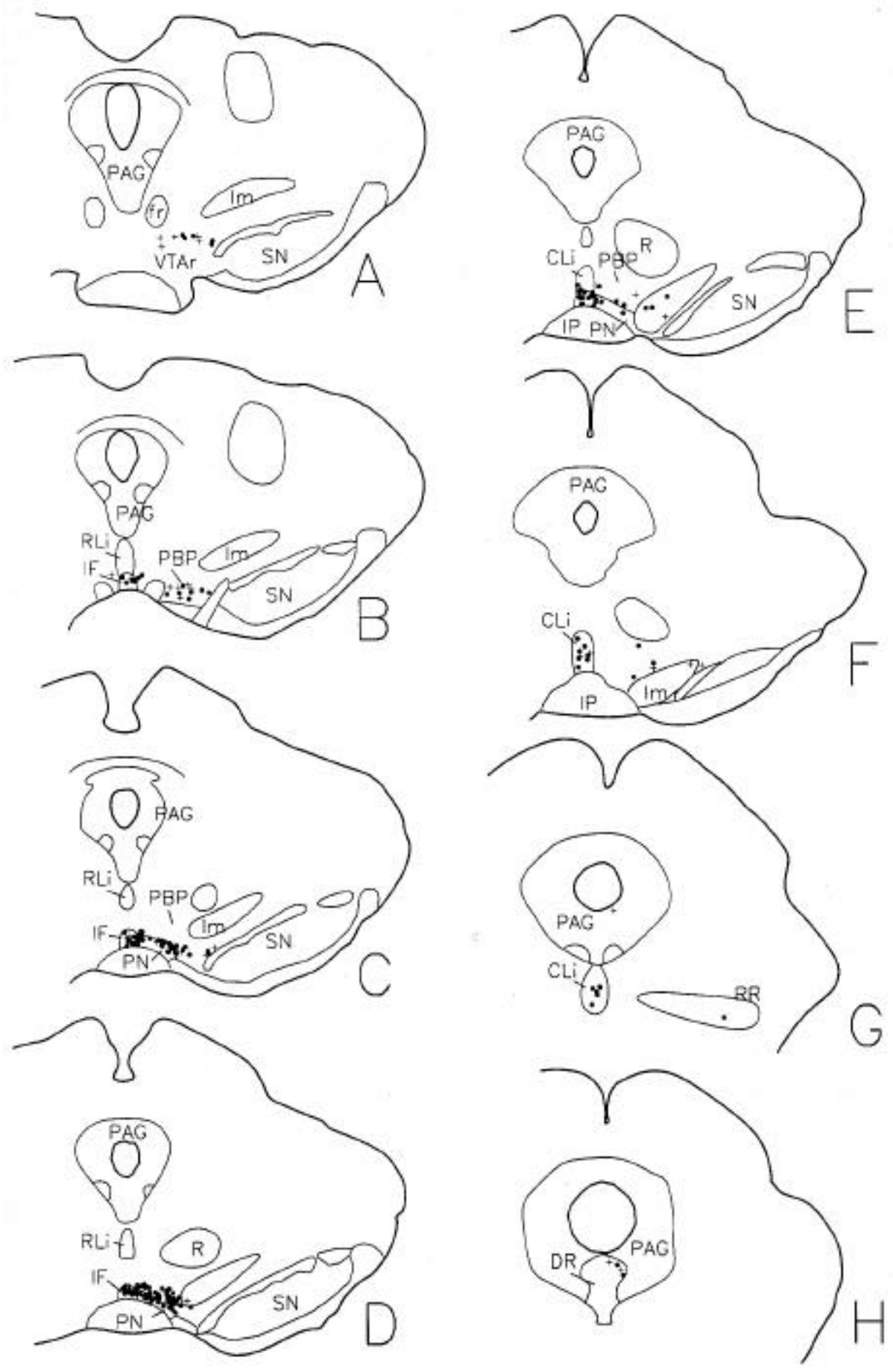

Figura 21: Representação esquemática da distribuição das células contendo FG (cruzes) e FG e TH (pontos) no caso 310, com injeção na porção caudodorsomedial da concha do núcleo acumbens. Cada símbolo representa uma célula. Para abreviaturas, ver lista. 
Figura 22: Porcentagem de células* duplamente marcadas em cada grupamento dopaminérgico em relação ao total visto por caso com injeção de FG na concha do núcleo acumbens.

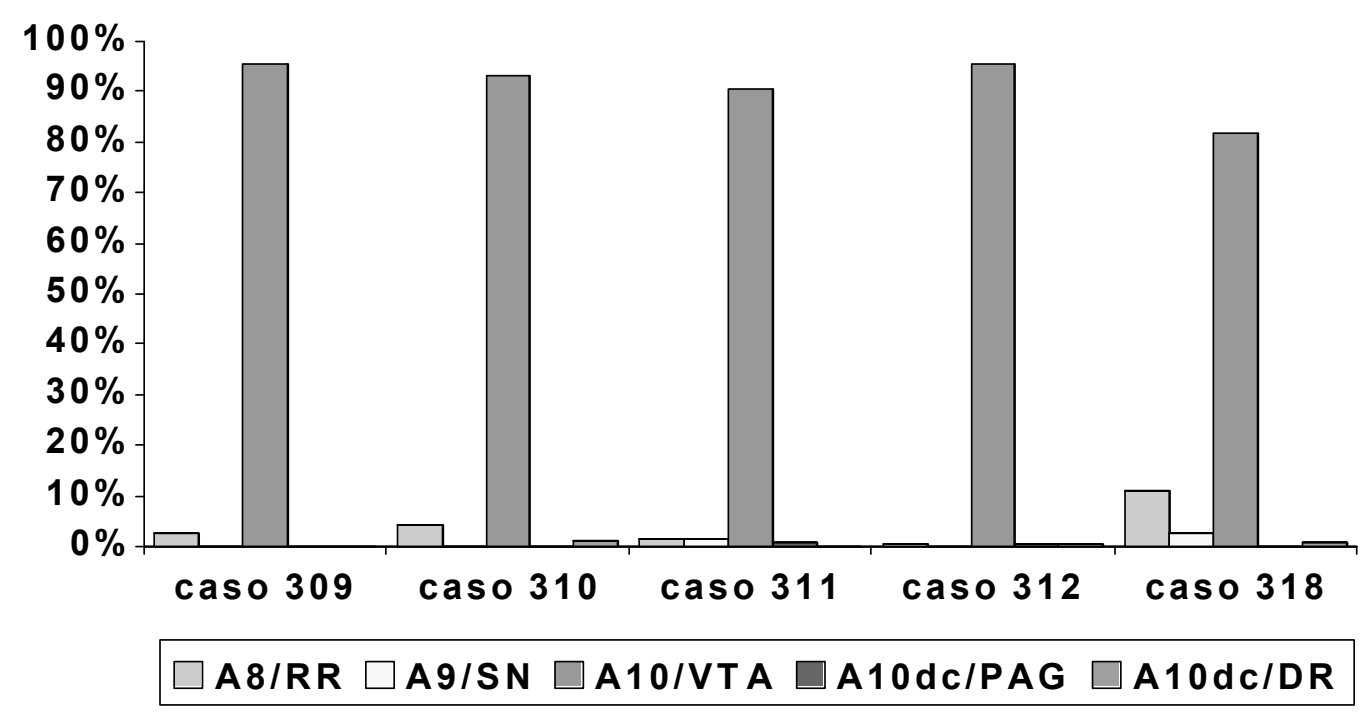

* as células foram contadas em um compartimento, sendo o intervalo entre os cortes adjacentes de $160 \mu \mathrm{m}$.

De maneira geral, a inervação dopaminérgica da concha do núcleo acumbens se origina quase que exclusivamente dos grupamentos mesencefálicos ventrais ipsolaterais, principalmente da área tegmental ventral. Foi observado ainda que as projeções dopaminérgicas da área tegmental ventral são organizadas topograficamente, de modo que as regiões mais dorsais da concha do núcleo acumbens são inervadas por setores ventrais da área tegmental ventral, e as regiões mais ventrais da concha do núcleo acumbens por setores dorsais da área tegmental ventral. Os casos 310 e 318 serão descritos detalhadamente e as diferenças entre eles e os casos 309, 311 e 312 serão comentadas a seguir.

Em todos os casos, poucas células duplamente marcadas foram identificadas no núcleo dorsal da rafe e na substância cinzenta periaquedutal (grupamento A10dc), bem como nos grupamentos A11, A12, A13 e A14. 
FG
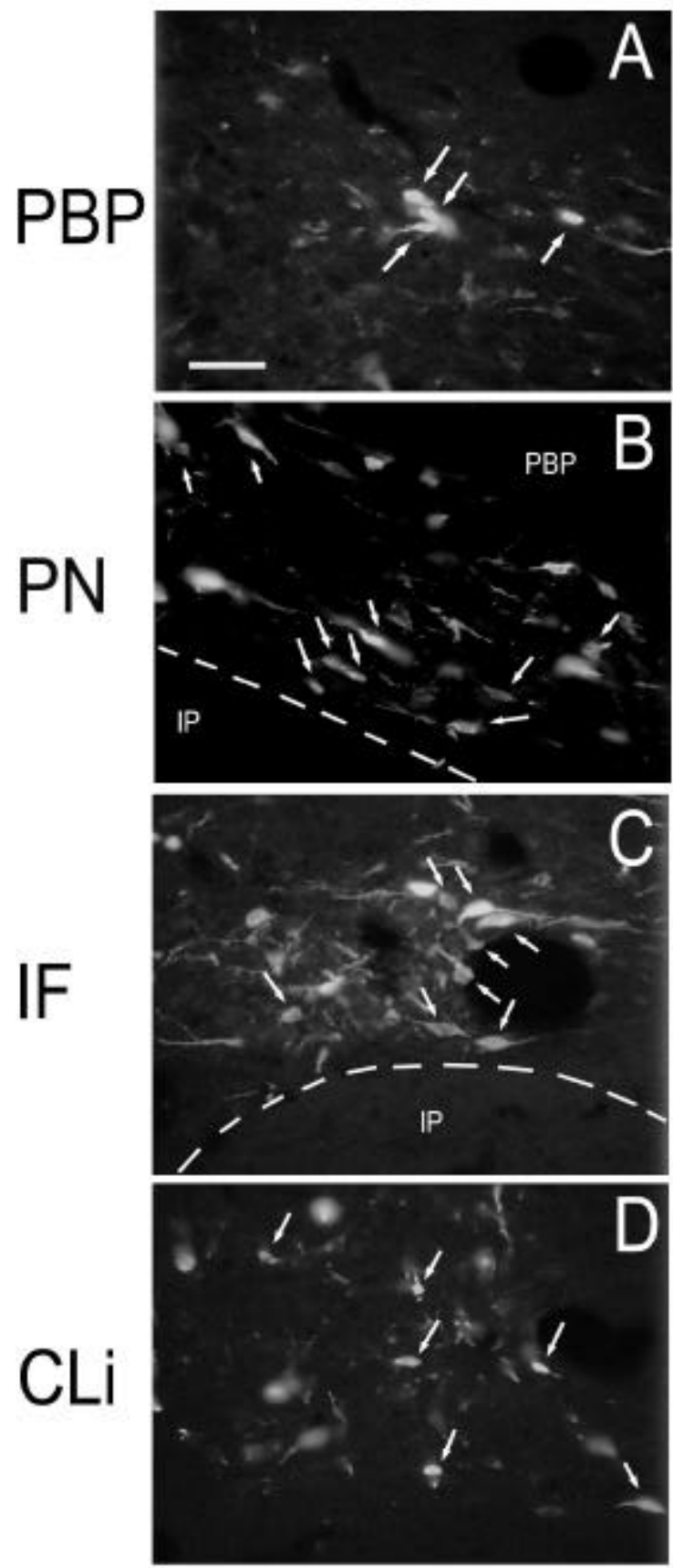

FIGURA 23: Fotomicrografias de células duplamente marcadas (indicadas pelas setas) presentes nos grupamentos mesencefálicos ventrais após a injeção de $F G$ na concha do núcleo acumbens. Células contendo FG: coluna àesquerda; células contendo $\mathrm{TH}$ : coluna à direita. $\mathrm{A}$ e $\mathrm{A}$ ': núcleo parabraquial pigmentoso; B e B': núcleo paranigral; C e C': núcleo interfascicular; D e D': núcleo linear caudal da rafe. Barra de escala em A (válida também para os demais campos) $=50 \mu \mathrm{m}$. Para abreviaturas, ver lista. 


\section{CASO 310}

\section{Diencéfalo}

Numerosas células retrogradamente marcadas foram vistas no tálamo posterior, nos núcleos paraventricular posterior, central medial, posteromediano e na porção medial do núcleo parafascicular. A marcação retrógrada é modesta no núcleo periventricular do hipotálamo e na substância cinzenta periventricular. Algumas poucas células retrogradamente marcadas foram notadas na zona incerta medial, e nenhuma foi vista no núcleo arqueado (Tabela 17). Não foram vistas células duplamente marcadas nos grupamentos dopaminérgicos diencefálicos no caso 310 (Tabela 18).

\section{Mesencéfalo}

$\mathrm{Na}$ área tegmental ventral foi observada uma densa marcação retrógrada no caso 310. Um número bem menor de células FG-ir foi visto no núcleo dorsal da rafe e no campo retrorrubral, e somente umas poucas foram vistas na substância negra e na substância cinzenta periaquedutal (Fig. 21; Tabela 17).

Os grupamentos A8, A9 e A10 são a grande fonte de inervação dopaminérgica da concha do núcleo acumbens e possuem juntos $97 \%$ de todas as células duplamente marcadas encontradas no caso 310, sendo que a grande maioria está situada na área tegmental ventral (Tabelas 18 e 19).

Campo retrorrubral

O campo retrorrubral apresenta um modesto número de células retrogradamente marcadas (Tabela 17), e as células duplamente marcadas representam menos de $5 \%$ do total encontrado neste caso (Tabelas 18 e19). 
Tabela 17: Número* de células contendo FG observadas nos núcleos correspondentes aos grupamentos dopaminérgicos mesodiencefálicos após injeção de FG na concha do núcleo acumbens.

\begin{tabular}{|c|c|c|c|c|c|c|}
\hline \multicolumn{2}{|c|}{ caso } & 309 & 310 & 311 & 312 & 318 \\
\hline A8 & $\mathrm{RR}$ & 15 & 14 & 13 & 42 & 57 \\
\hline \multirow[t]{3}{*}{ A9 } & SNcd & 4 & 1 & 6 & 4 & 4 \\
\hline & SNcv & 2 & 0 & 1 & 0 & 11 \\
\hline & SNI & 0 & 0 & 0 & 0 & 0 \\
\hline \multirow[t]{5}{*}{ A10 } & PBP & 188 & 86 & 204 & 229 & 239 \\
\hline & PN & 66 & 75 & 74 & 81 & 57 \\
\hline & RLi & 10 & 0 & 4 & 21 & 2 \\
\hline & CLi & 86 & 70 & 71 & 107 & 62 \\
\hline & IF & 51 & 59 & 81 & 112 & 18 \\
\hline \multicolumn{2}{|c|}{$\mathrm{A} 8 / \mathrm{A} 9 / \mathrm{A} 10$} & 5 & 3 & 27 & 12 & 17 \\
\hline A10dc & PAG & 6 & 2 & 5 & 21 & 5 \\
\hline A10dc & DR & 28 & 35 & 29 & 73 & 81 \\
\hline $\mathrm{A} 11$ & SCPV & 11 & 11 & 4 & 18 & 5 \\
\hline $\mathrm{A} 12$ & Arq & 0 & 0 & 0 & 3 & 0 \\
\hline A13 & ZIm & 3 & 4 & 1 & 11 & 2 \\
\hline $\mathrm{A} 14$ & PVH & 4 & 17 & 4 & 43 & 0 \\
\hline \multicolumn{2}{|c|}{ TOTAL } & 479 & 377 & 524 & 777 & 560 \\
\hline
\end{tabular}

${ }^{*}$ as células foram contadas em um compartimento, sendo o intervalo entre os cortes adjacentes de $160 \mu \mathrm{m}$.

Substância negra

Neste caso, foi vista apenas uma célula FG-ir na porção dorsal da substância negra, pars compacta, e esta não era duplamente marcada (Tabelas 17 e 18). Área tegmental ventral

A marcação retrógrada é densa e relativamente homogênea nos diversos núcleos da área tegmental ventral, salvo no núcleo linear rostral da rafe, onde não foram vistas células FG-ir (Fig. 21; Tabela 17). Dentre as células retrogradamente 
marcadas localizadas na área tegmental ventral, a grande maioria (83\%) é duplamente marcada, e elas representam pouco mais de $90 \%$ do total células duplamente marcadas encontradas neste caso (Fig. 22; Tabela 19).

Tabela 18: Número* de células contendo FG e TH observadas nos núcleos correspondentes aos grupamentos dopaminérgicos mesodiencefálicos após injeção de FG na concha do núcleo acumbens.

\begin{tabular}{|c|c|c|c|c|c|c|}
\hline \multicolumn{2}{|c|}{ caso } & 309 & 310 & 311 & 312 & 318 \\
\hline A8 & $\mathrm{RR}$ & 8 & 11 & 6 & 3 & 34 \\
\hline \multirow[t]{3}{*}{ A9 } & SNcd & 0 & 0 & 5 & 0 & 2 \\
\hline & SNcv & 0 & 0 & 1 & 0 & 8 \\
\hline & SNI & 0 & 0 & 0 & 0 & 0 \\
\hline \multirow[t]{5}{*}{ A10 } & PBP & 125 & 68 & 145 & 135 & 176 \\
\hline & PN & 61 & 67 & 65 & 68 & 41 \\
\hline & RLi & 4 & 0 & 1 & 8 & 1 \\
\hline & CLi & 77 & 59 & 55 & 77 & 46 \\
\hline & IF & 45 & 47 & 69 & 99 & 12 \\
\hline \multicolumn{2}{|c|}{ A8/A9/A10 } & 2 & 2 & 18 & 8 & 9 \\
\hline A10dc & PAG & 1 & 1 & 0 & 1 & 1 \\
\hline A10dc & DR & 3 & 4 & 1 & 4 & 4 \\
\hline A11 & SCPV & 0 & 0 & 1 & 1 & 0 \\
\hline A12 & Arq & 0 & 0 & 0 & 0 & 0 \\
\hline A13 & Zim & 0 & 0 & 0 & 0 & 0 \\
\hline A14 & $\mathrm{PVH}$ & 1 & 0 & 0 & 0 & 0 \\
\hline \multicolumn{2}{|c|}{ TOTAL } & 327 & 259 & 367 & 404 & 334 \\
\hline
\end{tabular}

* as células foram contadas em um compartimento, sendo o intervalo entre os cortes adjacentes de $160 \mu \mathrm{m}$.

Os núcleos parabraquial pigmentoso e paranigral contribuem cada um com pouco mais de $25 \%$ do total de células duplamente marcadas encontradas no caso 310 (Fig. 22 e 23; Tabela 18). Estas situam-se em toda extensão do núcleo paranigral e no setor ventral do núcleo parabraquial pigmentoso (Fig. 21). Os outros 
$40 \%$ das células duplamente marcadas vistas neste caso estão homogeneamente distribuídos entre os núcleos interfascicular e linear caudal da rafe. A Figura 24 ilustra a distribuição relativa das células FG-ir e TH-ir no núcleos da área tegmental ventral.

Tabela 19: Porcentagem de células* duplamente marcadas encontradas em cada grupamento dopaminérgico do mesencéfalo ventral em relação ao total visto por caso com injeção de FG na concha do núcleo acumbens.

\begin{tabular}{c|ccccc}
\hline caso & 309 & 310 & 311 & 312 & 318 \\
\hline A8/RR & $\mathbf{2 , 7 \%}$ & $\mathbf{4 , 2} \%$ & $\mathbf{1 , 8 \%}$ & $\mathbf{0 , 7 \%}$ & $\mathbf{1 1 \%}$ \\
A9/SN & 0 & 0 & $1,6 \%$ & 0 & $3 \%$ \\
A10/VTA & $95 \%$ & $93 \%$ & $90 \%$ & $95 \%$ & $\mathbf{8 1 \%}$ \\
\hline
\end{tabular}

* as células foram contadas em um compartimento, sendo o intervalo entre os cortes adjacentes de $160 \mu \mathrm{m}$.

Figura 24: Porcentagem de células* duplamente marcadas em cada subnúcleo em relação ao total de células duplamente macadas na área tegmental ventral após injeção de FG na concha do núcleo acumbens.

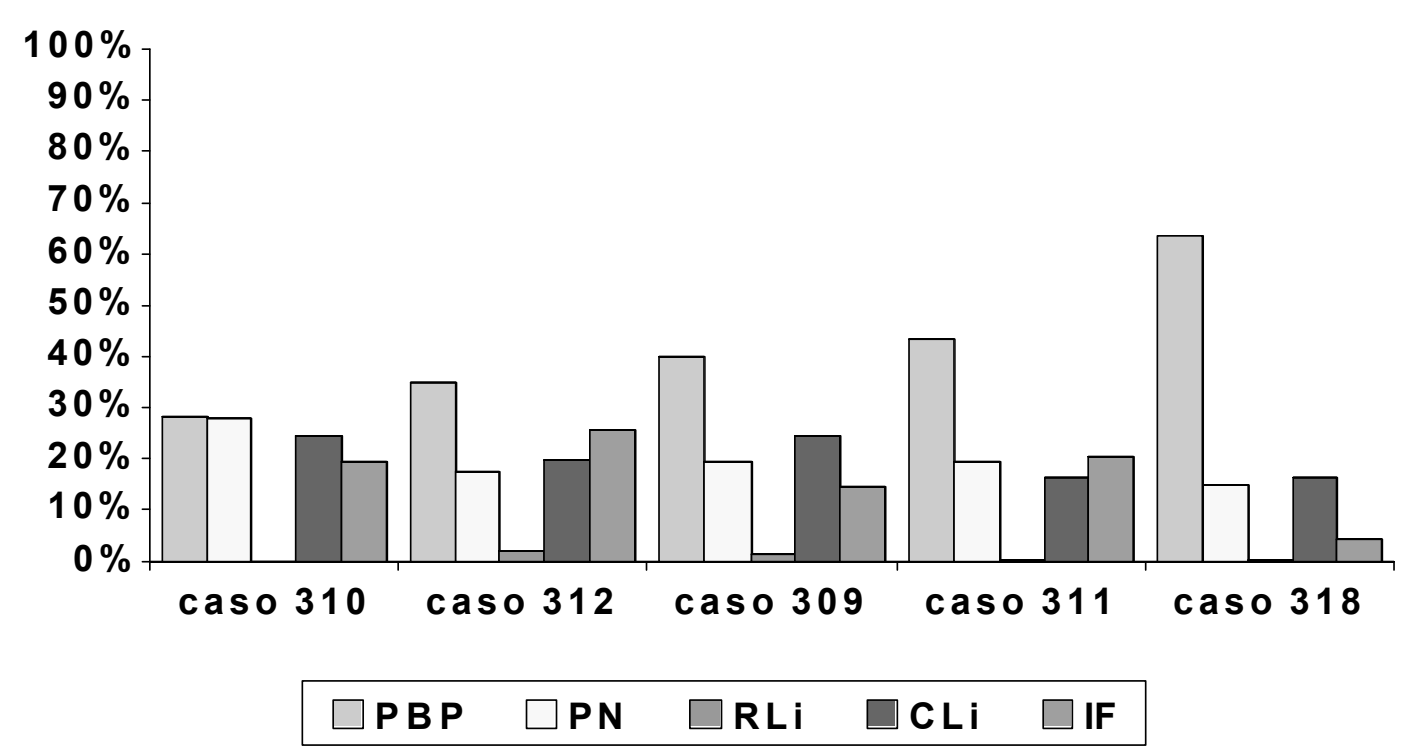

* as células foram contadas em um compartimento, sendo o intervalo entre os cortes adjacentes de $160 \mu \mathrm{m}$. 

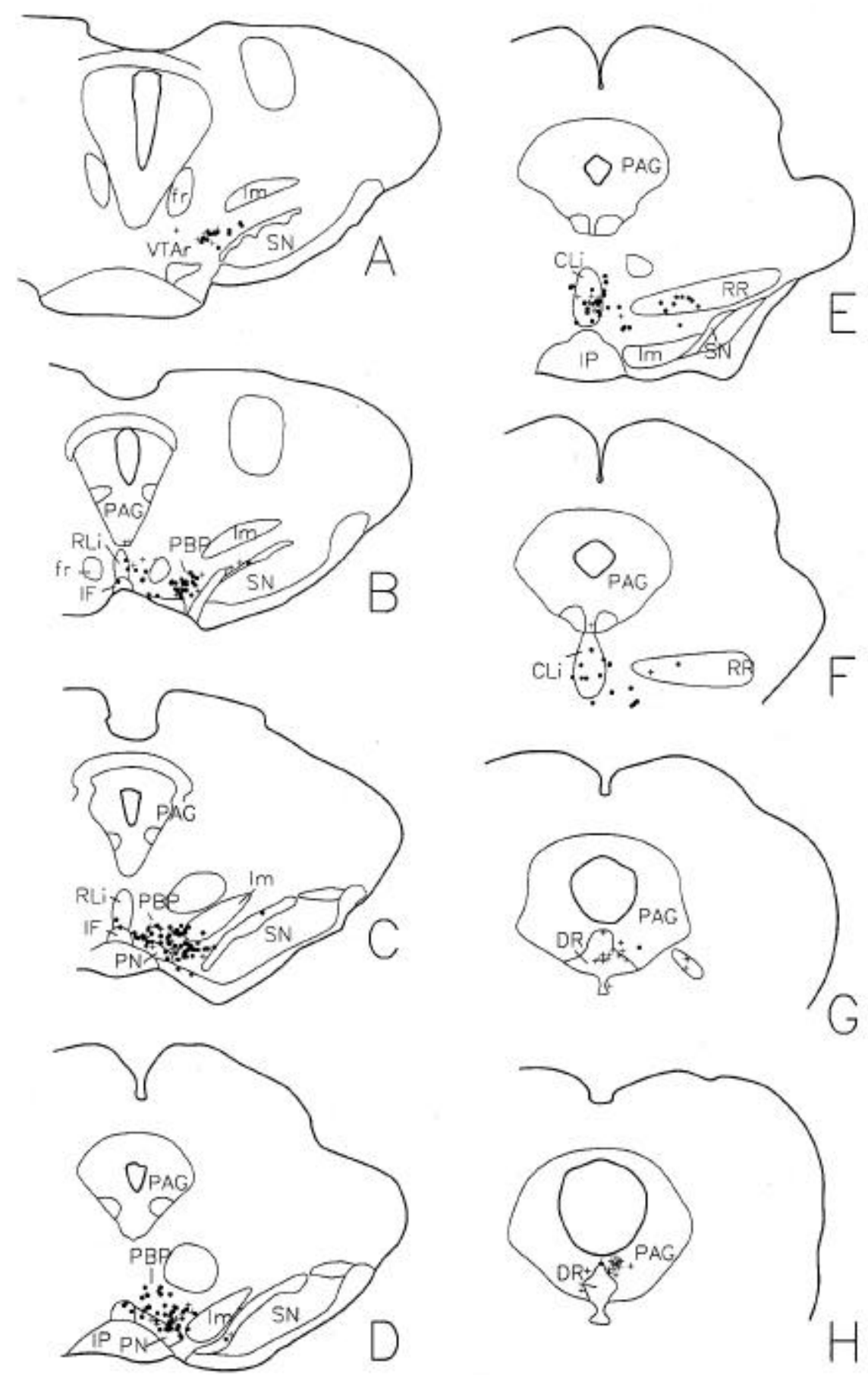

Figura 25: Representação esquemática da distribuição das células contendo FG (cruzes) e FG e TH (pontos) no caso 318, com injeção na porção ventral da concha do núcleo acumbens. Cada símbolo representa uma célula. Para abreviaturas, ver lista. 
Substância cinzenta periaquedutal

Raras células FG-ir foram detectadas na coluna lateral da substância cinzenta periaquedutal, e apenas uma delas era duplamente marcada (Fig. 21; Tabelas 17 e 18).

Núcleo dorsal da rafe

Um número moderado de células retrogradamente marcadas foi observado no núcleo dorsal da rafe, principalmente no seu setor dorsal e lateral (Fig. 21). Destas, poucas eram duplamente marcadas, representando menos de $2 \%$ do total de células duplamente marcadas encontradas no caso (Tabela 20).

Tabela 20: Porcentagem de células* duplamente marcadas encontradas na substância cinzenta central e no núcleo dorsal da rafe em relação ao total visto por caso com injeção de FG na concha do núcleo acumbens.

\begin{tabular}{c|ccccc}
\hline caso & 309 & 310 & 311 & 312 & 318 \\
\hline A11/SCPV & $\mathbf{0}$ & $\mathbf{0}$ & $\mathbf{0 , 2} \%$ & $\mathbf{0 , 2} \%$ & $\mathbf{0}$ \\
A10dc/PAG & $\mathbf{0 , 3} \%$ & $\mathbf{0 , 3} \%$ & $\mathbf{0}$ & $\mathbf{0 , 2} \%$ & $\mathbf{0 , 2} \%$ \\
A10dc/DR & $\mathbf{0 , 9} \%$ & $\mathbf{1 , 5 \%}$ & $\mathbf{0 , 2} \%$ & $\mathbf{0 , 9} \%$ & $\mathbf{1 , 1 \%}$ \\
\hline
\end{tabular}

${ }^{*}$ as células foram contadas em um compartimento, sendo o intervalo entre os cortes adjacentes de $160 \mu \mathrm{m}$.

\section{CASO 318}

\section{Diencéfalo}

A marcação retrógrada no tálamo posterior é semelhante àobservada no caso 310. Um pequeno número de células retrogradamente marcadas foi detectado na zona incerta medial e na substância cinzenta periventricular, e nenhuma foi vista nos núcleos arqueado e periventricular do hipotálamo. Neste caso não foi encontrada nenhuma célula duplamente marcada nos grupamentos $A 11, A 12, A 13$ e A14 (Tabelas 17 e 18). 


\section{Mesencéfalo}

A marcação retrógrada do mesencéfalo está concentrada nos grupamentos mesencefálicos ventrais, sendo a maior parte dela localizada na área tegmental ventral. Um número moderado de células FG-ir foi encontrado no campo retrorrubral e no núcleo dorsal da rafe; e apenas algumas estavam na substância negra, pars compacta, e na substância cinzenta periaquedutal (Fig. 25; Tabela 17).

A grande maioria das aferências dopaminérgicas da parte ventral da concha do núcleo acumbens se origina nos grupamentos A8, A9 e A10. Em conjunto, estes grupamentos contém cerca de $95 \%$ de todas as células duplamente marcadas encontradas neste caso, sendo que a maioria está na área tegmental ventral (Fig. 22; Tabela 19).

\section{Campo retrorrubral}

Um número moderado de células retrogradamente marcadas foi encontrado no campo retrorrubral, mais concentradas no seu setor medial (Fig. 25). Mais da metade destas células são também TH-ir, e representam cerca de $10 \%$ do total de células duplamente marcadas encontradas no caso 318 (Fig. 22; Tabela 19).

Substância negra

Poucas células FG-ir foram vistas na substância negra, pars compacta, a maioria em sua porção ventral, e algumas na sua porção dorsal. Algumas destas são duplamente marcadas e representam menos de $5 \%$ do total encontrado no caso 318 (Fig. 22; Tabela 19).

Área tegmental ventral

A marcação retrógrada da área tegmental ventral está predominantemente localizada no núcleo parabraquial pigmentoso, sendo mais densa em seu setor 
lateral. Um número moderado de células retrogradamente marcadas foi visto na parte dorsal do núcleo paranigral, no núcleo linear caudal da rafe, e em menor grau, no núcleo interfascicular (Fig. 25; Tabela 17). Raras células retrogradamente marcadas foram identificadas no núcleo linear rostral da rafe.

Grande parte das células FG-ir vistas na área tegmental ventral são também TH-ir (73\%). Elas representam cerca de $80 \%$ do total de células duplamente marcadas encontrado no caso 318 (Fig. 22, Tabela 19). Dentre os núcleos da área tegmental ventral, o núcleo parabraquial pigmentoso é o que concentra o maior número de células FG-ir e TH-ir (cerca de $50 \%$ do total de células duplamente marcadas presentes neste caso; Fig. 24). Os núcleos paranigral e linear caudal da rafe, por sua vez, contribuem juntos com cerca de $25 \%$ de todas as células duplamente marcadas encontradas neste caso. Um número menor de células FG-ir foi visto no núcleo interfascicular, e apenas raras no núcleo linear rostral da rafe (Tabela 18).

Substância cinzenta periaquedutal

Um número muito pequeno de células retrogradamente marcadas foi detectado nas colunas lateral e ventrolateral da substância cinzenta periaquedutal, sendo que apenas uma delas era duplamente marcada (Tabela 18).

Núcleo dorsal da rafe

A marcação retrógrada no núcleo dorsal da rafe é moderada e está localizada principalmente em seu setor dorsal e lateral (Fig. 25). Algumas poucas células eram duplamente marcadas, representando por volta de 1\% do total de células FG-ir e THir vistas no caso 318 (Tabelas 18 e 20). 


\section{OUTROS CASOS}

À semelhança dos casos 310 e 318 , nos outros casos com injeção de FG na concha do núcleo acumbens $(309,311$ e 312), as células retrogradamente e duplamente marcadas estão localizadas principalmente na área tegmental ventral. É interessante notar, entretanto, que o padrão de distribuição destas células na área tegmental ventral nos casos 309, 311 e 312 é um padrão intermediário entre os descritos para os casos 310 e 318 (Fig. 26). Assim, a marcação retrógrada na área tegmental ventral está situada em setores intermediários no eixo dorsoventral, ou seja, é mais dorsal do que marcação retrógrada vista no caso 310, porém não tanto quanto a vista no caso 318. Da mesma maneira, a análise quantitativa demonstra que a porcentagem de células duplamente marcadas nos diferentes núcleos da área tegmental ventral também apresenta valores intermediários entre aqueles vistos nos casos 310 e 318 (Fig. 24).

Não foram observadas diferenças significativas entre os casos 309, 311 e 312 e os casos 310 e 318 no que diz respeito àdistribuição das células retrogradamente marcadas no campo retrorrubral, na substância negra, na substância cinzenta periaquedutal e no núcleo dorsal da rafe (Tabelas 6-8 e 10).

As Figuras 27-30 ilustram a porcentagem média de células contendo apenas FG ou contendo FG e TH, no eixo vertical, nos casos com injeção nos núcleos central da amígdala (CeA), intersticial lateral da estria terminal (BSTI), amígdala expandida sublenticular (SLEA) e núcleo intersticial do ramo posterior da comissura anterior (IPAC), representados no eixo horizontal. 


\section{FG}
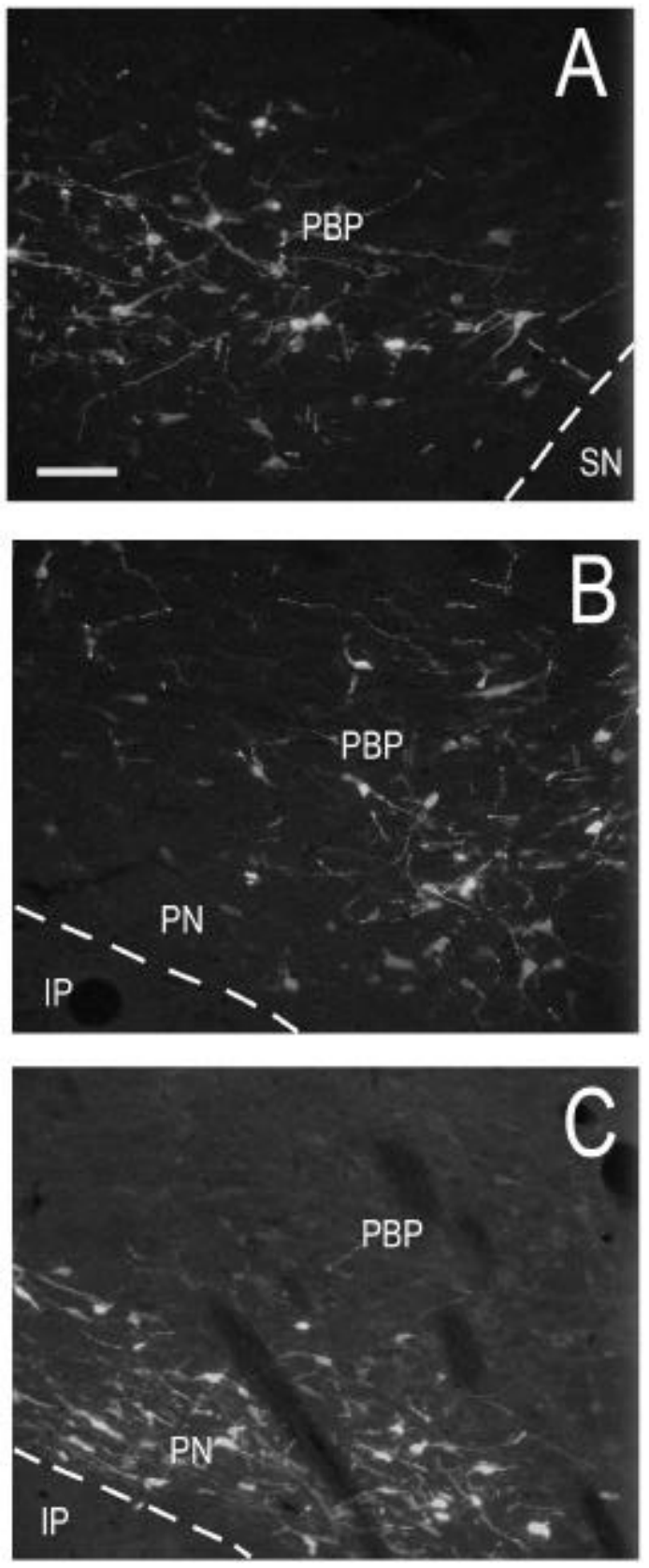
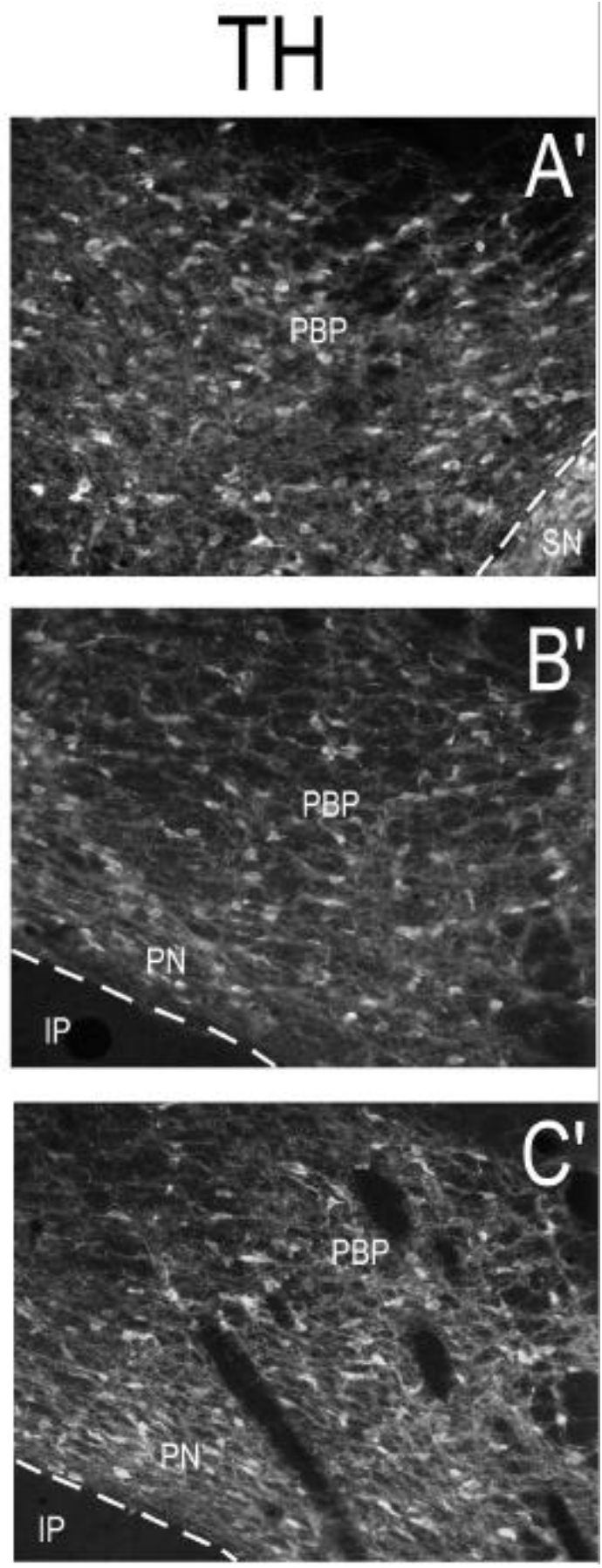

Figura 26: Fotomicrografias ilustrando a organização topográfica dorsoventral invertida das projeções da área tegmental ventral para a concha do núcleo acumbens nos casos 318 ( $A, A^{\prime}, \mathrm{B}$ e B') e 310 (C e C'). Células contendo FG: Coluna æ̀squerda; célula s contendo TH: coluna àdireita. Note que em C-C' as células contendo FG estão distribuídas no setor ventral da área tegmental ventral; em A-A' e B-B' este setor ventral apresenta poucas células contendo FG. Barra de escala em $A$ (válida também para os demais campos) $=100 \mu \mathrm{m}$. Para abreviaturas, ver lista. 
Figura 27: Porcentagem média de células* contendo apenas FG (coluna pontilhada) e contendo FG e TH (coluna negra) em relação às células retrogradamente marcadas encontradas na área tegmental ventral após injeção de FG nos diferentes componentes da amígdala expandida central e na concha do

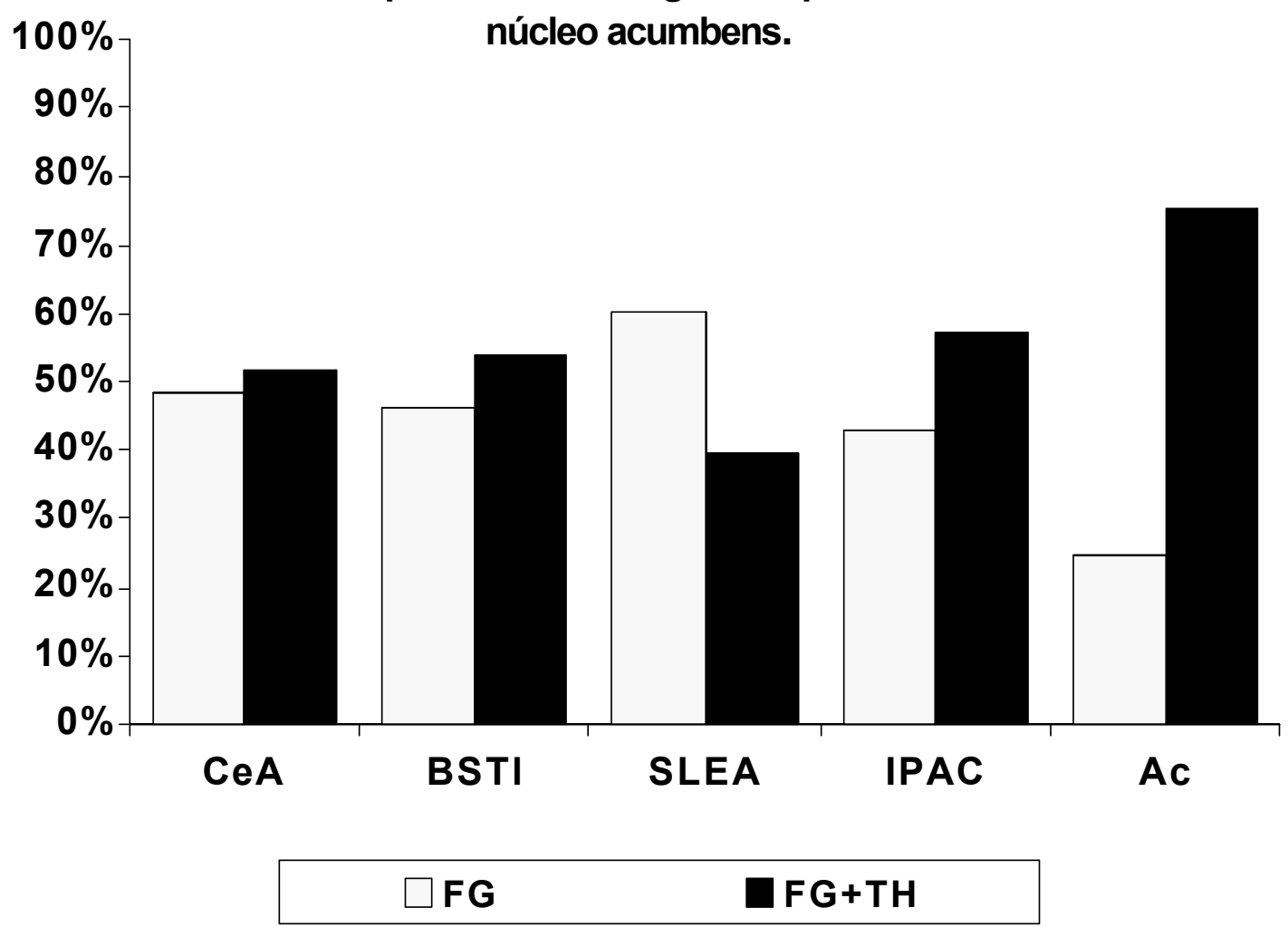

*as células na área tegmental ventral foram contadas em um compartimento, sendo o intervalo entre os cortes adjacentes de $160 \mu \mathrm{m}$. 
Figura 28: Porcentagem média de células* contendo FG (coluna pontilhada) ou contendo $\mathrm{FG} \mathrm{e} \mathrm{TH} \mathrm{(coluna} \mathrm{negra)} \mathrm{em} \mathrm{relação} \mathrm{às} \mathrm{células} \mathrm{retrogradamente}$ marcadas encontradas no campo retromubral após injeção de FG nos diferentes componentes da amigdala expandida central ena concha do núcleo acumbens.

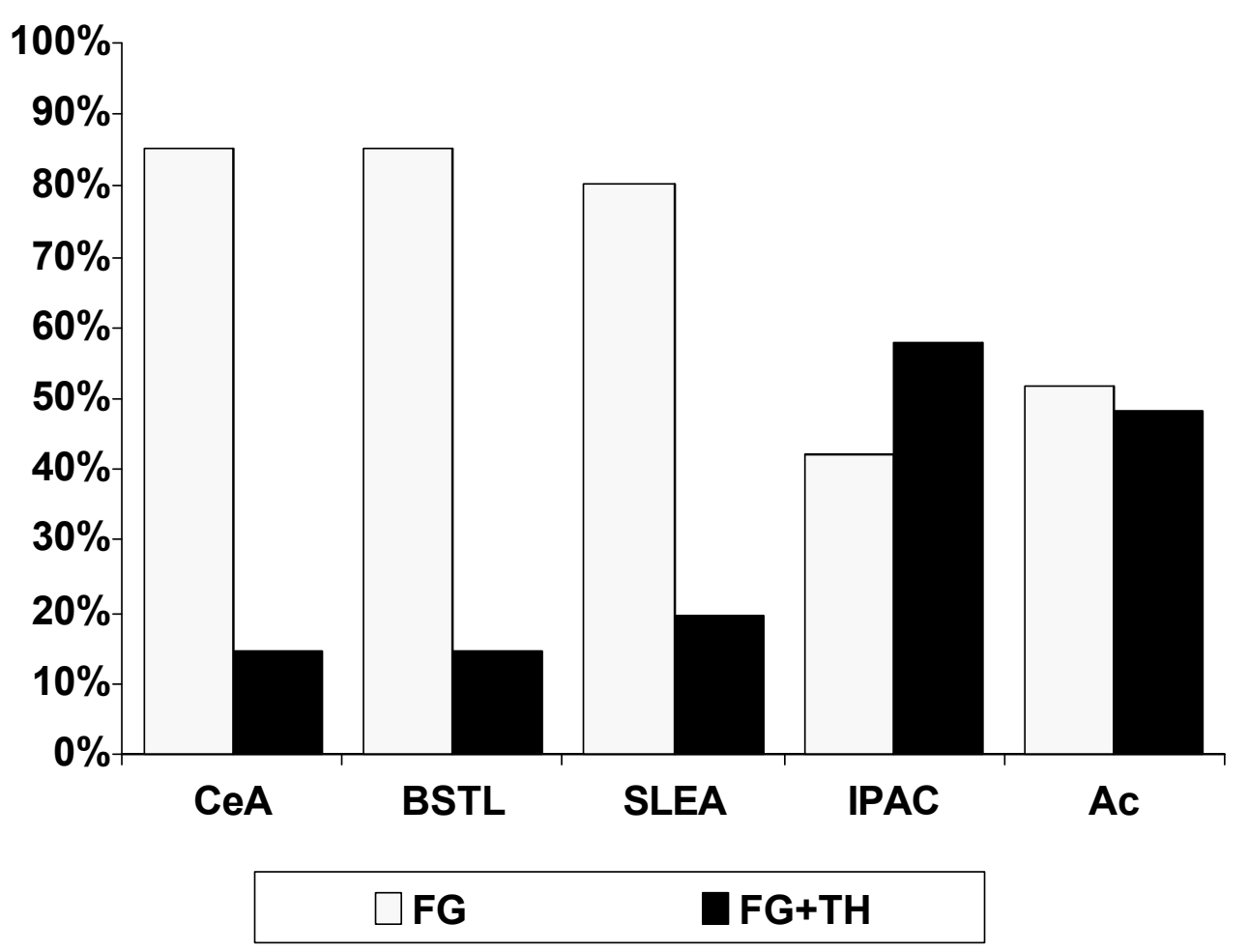

*as células no campo retrorrubral foram contadas em um compartimento, sendo o intervalo entre os cortes adjacentes de $160 \mu \mathrm{m}$. 
Figura 29: Porcentagem média de células* contendo FG (coluna pontilhada) e contendo FG e TH (coluna negra) em relação às células retrogradamente marcadas encontradas na substância cinzenta periaquedutal após injeção de FG nos diferentes componentes da amígdala expandida centra.

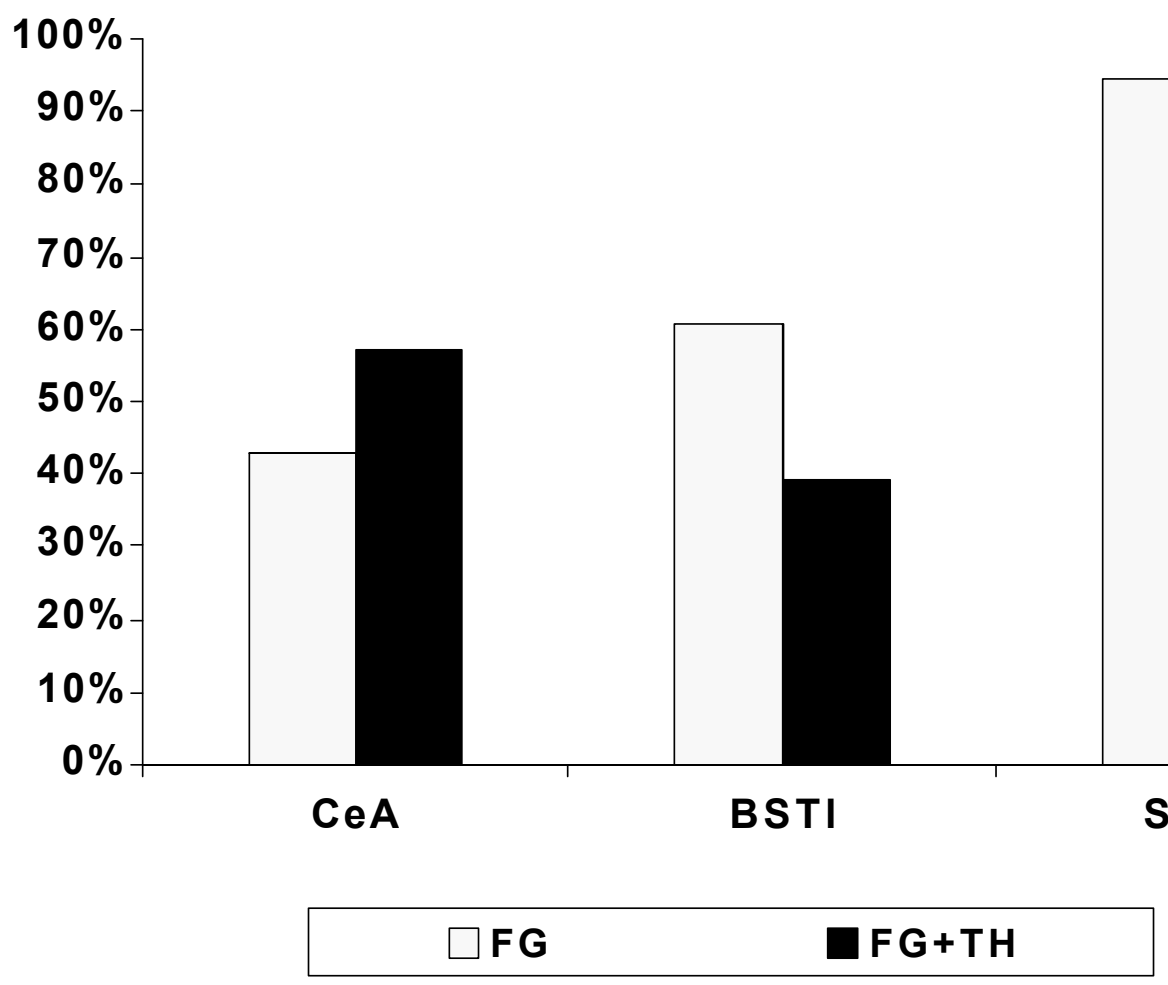

*as células na substância cinzenta periaquedutal foram contadas em um compartimento, sendo o intervalo entre os cortes adjacentes de $160 \mu \mathrm{m}$. 
Figura 30: Porcentagem média de células* contendo FG (coluna pontilhada) e contendo FG e TH (coluna negra) em relação às células retrogradamente marcadas encontradas no núcleo dorsal da rafe após injeção de FG nos diferentes componentes da amígdala expandida central.

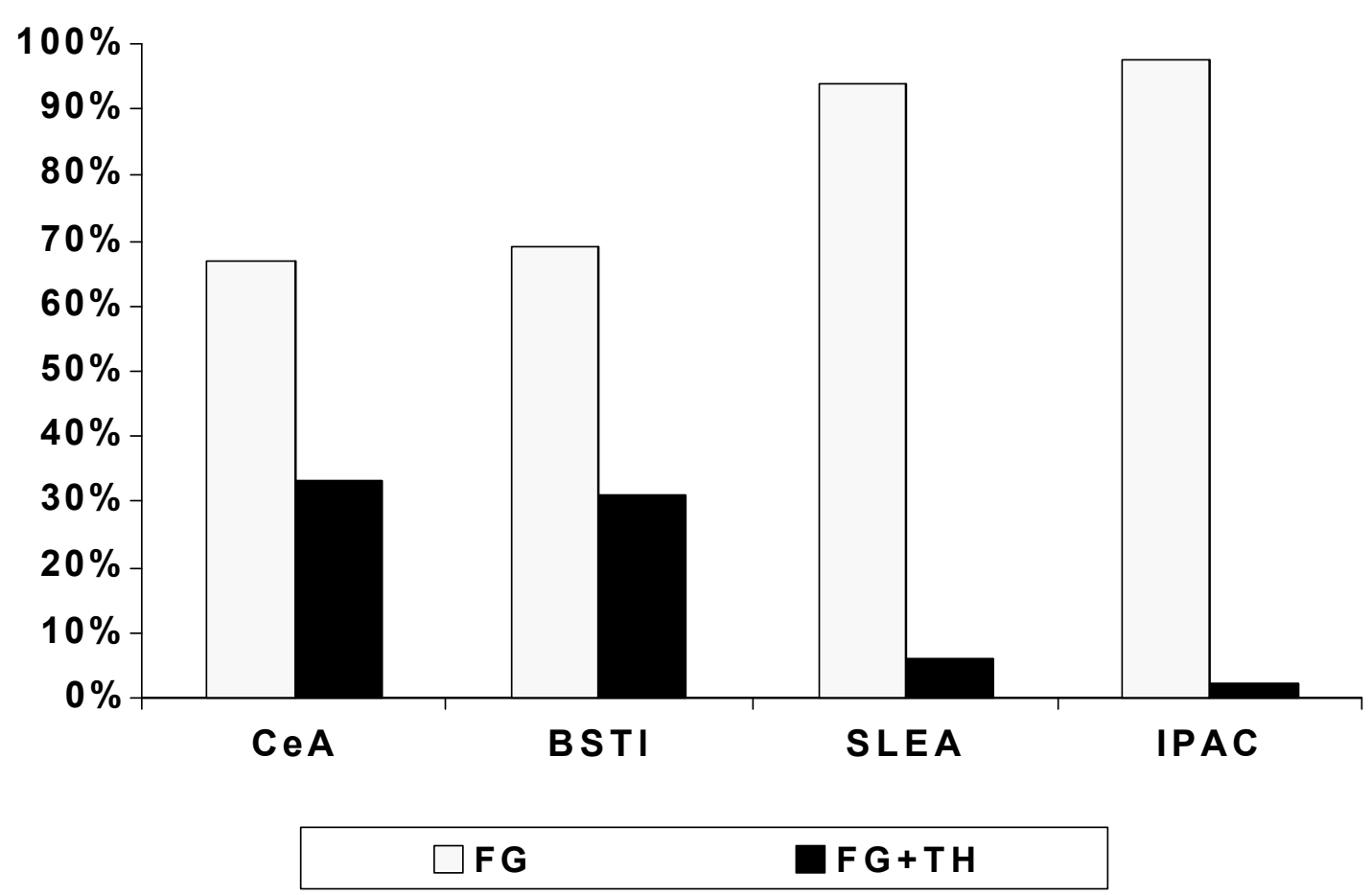

*as células no núcleo dorsal da rafe foram contadas em um compartimento, sendo o intervalo entre os cortes adjacentes de $160 \mu \mathrm{m}$. 


\section{EXPERIMENTOS PARA DETECÇÃO DA DOPAMINA}

De dez animais que receberam injeção de FG tendo como alvo o núcleo central da amígdala, em três casos a injeção estava praticamente restrita a este núcleo. Estes casos $(347,348$ e 349) foram processados por imunofluorescência para detecção da dopamina. Nos casos 347 e 348, o centro da injeção está localizado na divisão lateral do núcleo central da amígdala, sendo um pouco mais caudal no caso 347 . No caso 349, a injeção de FG está na parte ventral da divisão medial do núcleo amigdalóide central (Fig. 3).

Cortes adjacentes de um compartimento, espaçados por $100 \mu \mathrm{m}$, e contendo a substância cinzenta periaquedutal e o núcleo dorsal da rafe foram analisados. De um modo geral, a presença de autofluorescência decorrente da fixação do tecido com glutaraldeído dificultou a análise deste material, prejudicando a visualização das células retrogradamente marcadas e das células imunorreativas ao anticorpo antidopamina (DA-ir). Resultados semelhantes foram observados nos casos 347, 348 e 349.

Tabela 21: Número* de células contendo FG encontradas na substância cinzenta periaquedutal e no núcleo dorsal da rafe após injeção de FG no núcleo central da amígdala.

\begin{tabular}{c|ccc}
\hline caso & 347 & 348 & 349 \\
\hline PAG & $\mathbf{9 1}$ & $\mathbf{2 7 5}$ & $\mathbf{1 3 3}$ \\
DR & $\mathbf{9 2}$ & $\mathbf{1 5 2}$ & $\mathbf{1 8 9}$ \\
\hline
\end{tabular}

* as células foram contadas em um compartimento, sendo o intervalo entre os cortes adjacentes de $100 \mu \mathrm{m}$.

Um grande número de células retrogradamente marcadas pôde ser identificado nas colunas lateral e ventrolateral da substância cinzenta periaquedutal, uma parcela significativa destas era duplamente marcada (12\% a 23\%; Tabelas 21 e 
22). No núcleo dorsal da rafe, a marcação retrógrada é abundante (Tabela 21) e não apresenta distribuição preferencial. Aproximadamente $6 \%$ a $11 \%$ destas células são duplamente marcadas e estão situadas principalmente no setor ventral deste núcleo.

Tabela 22: Número* de células contendo FG e dopamina encontradas na substância cinzenta periaquedutal e no núcleo dorsal da rafe após injeção de FG no núcleo central da amígdala.

\begin{tabular}{c|ccc}
\hline caso & 347 & 348 & 349 \\
\hline PAG & 21 & 53 & 16 \\
DR & 6 & 18 & 11
\end{tabular}

* as células foram contadas em um compartimento, sendo o intervalo entre os cortes adjacentes de $100 \mu \mathrm{m}$.

O número de células DA-ir no mesencéfalo visto nestes casos é menor do que as células TH-ir vistas em outros casos. Comparando-se a quantidade de células no campo retrorrubral, em dois cortes representativos de um caso processado com o anticorpo anti-dopamina e de outro processado com o anticorpo anti-TH, observamos que as células DA-ir representam $75 \%$ do número de células TH-ir. No núcleo dorsal da rafe e substância cinzenta periaquedutal estas diferenças quantitativas são ainda mais acentuadas. Assim, as células DA-ir observadas no núcleo dorsal da rafe e substância cinzenta periaquedutal representam, respectivamente, apenas $45 \%$ e $30 \%$ das células $\mathrm{TH}$-ir. Este fato pode ter contribuído para que as porcentagens de células duplamente marcadas observadas na substância cinzenta periaquedutal e no núcleo dorsal da rafe, nos casos processados com anticorpo anti-dopamina, fosse menor do que as respectivas porcentagens vistas nos casos processados com anticorpo anti-TH (Fig. 31). 
Figura 31: Porcentagem média de células* duplamente marcadas em relação às células retrogradamente marcadas na substância cinzenta periaquedutal ou no núcleo dorsal da rafe nos casos com injeção de FG no núcleo central da amígdala processados com anticorpo anti-TH (coluna pontilhada) ou anti-dopamina (coluna negra).

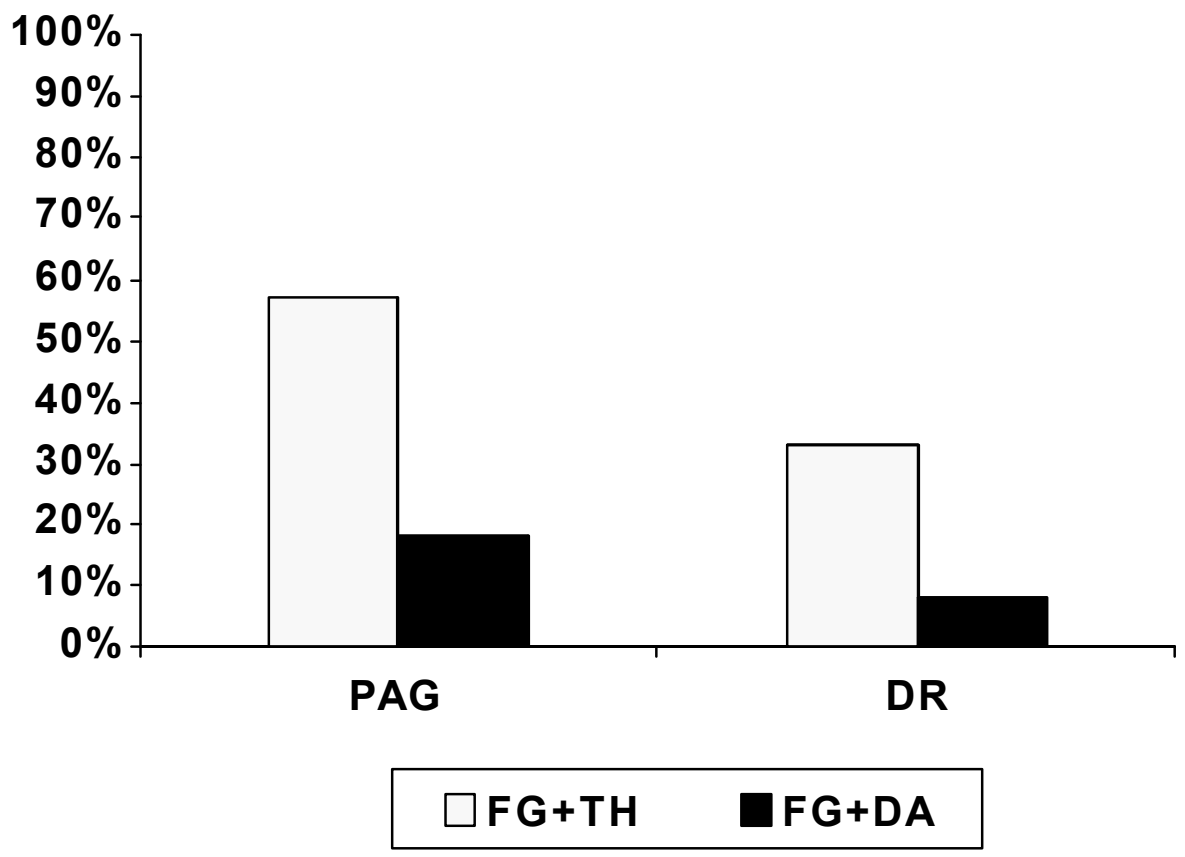

\footnotetext{
* as células na substância cinzenta periaquedutal ou no núcleo dorsal da rafe foram contadas em um compartimento, sendo o intervalo entre os cortes adjacentes de $160 \mu \mathrm{m}$ nos casos processados com anti-TH, e de $100 \mu \mathrm{m}$ nos casos processados com anti-dopamina.
} 


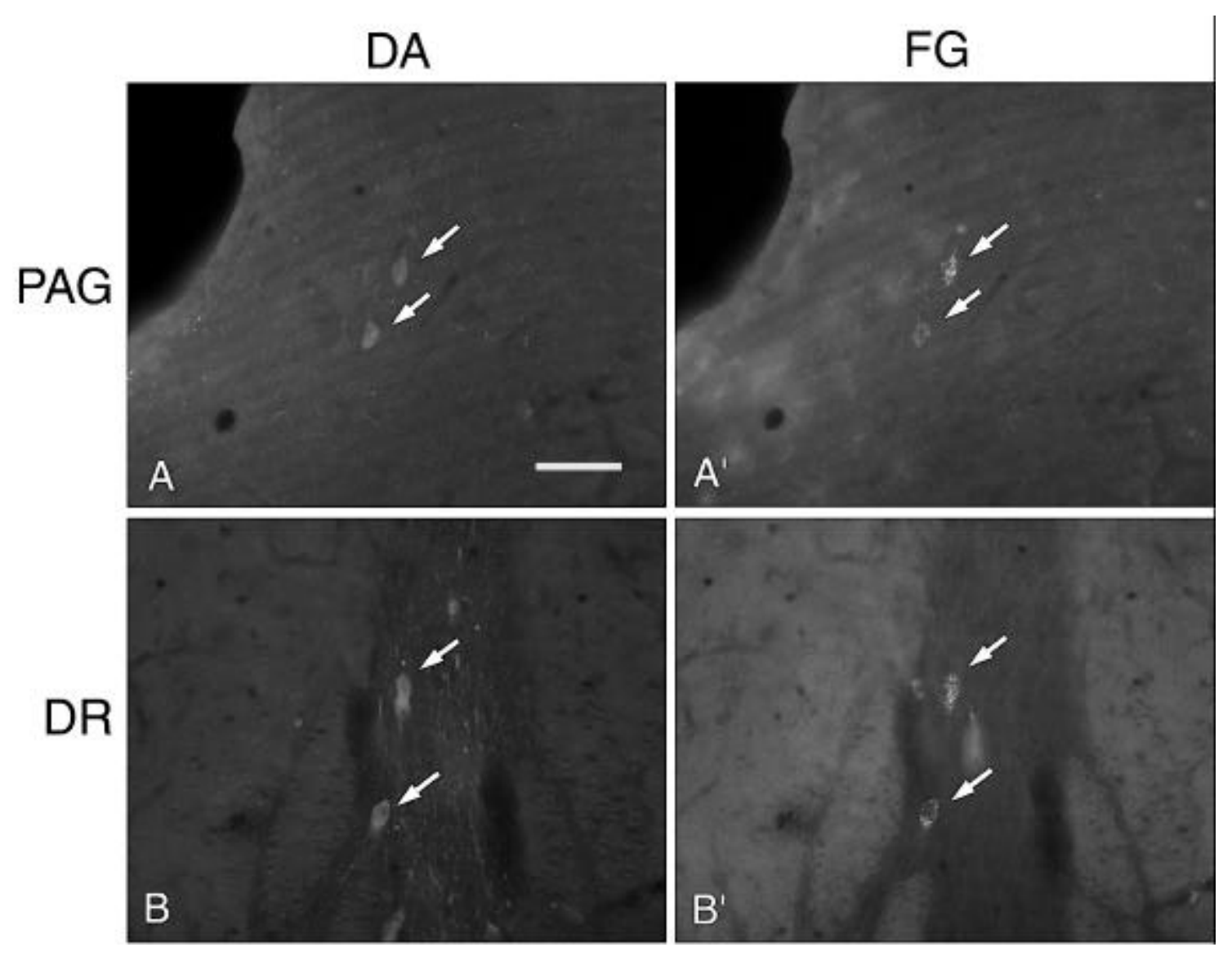

Figura 32: Fotomicrografias de células duplamente marcadas (indicadas pelas setas) presentes na substância cinzenta periaquedutal ( $A$ e $A^{\prime}$ ) e no núcleo dorsal da rafe (B e B') após injeção de $F G$ no núcleo central da amígdala. Células contendo FG: Coluna àdireita; células contendo dopamina: coluna àesquerda. Barra de escala em A (válida também para os demais campos) $=50 \mu \mathrm{m}$. Para abreviaturas, ver lista. 


\section{DISCUSSÃO}

Nossas observações indicam que a inervação dopaminérgica da amígdala expandida central e da concha do núcleo acumbens deriva essencialmente de estruturas mesencefálicas, sendo a contribuição dos grupamentos diencefálicos insignificante.

Uma comparação da origem da inervação dopaminérgica dos diferentes componentes da amígdala expandida central e da concha do núcleo acumbens não tinha sido previamente feita. Nossas observações indicam que os núcleos central da amígdala e intersticial lateral da estria terminal possuem um padrão de inervação dopaminérgica muito semelhante. Por outro lado, a inervação dopaminérgica do corredor ventral da amígdala expandida central (representado pela amígdala expandida sublenticular e pelo núcleo intersticial do ramo posterior da comissura anterior) e da concha do acumbens apresentam características que diferenciam estes territórios entre si, assim como dos pólos rostral e caudal da amígdala expandida central (i.e., os núcleos intersticial lateral da estria terminal e central da amígdala).

\section{Projeções dos grupamentos dopaminérgicos diencefálicos}

Projeções do grupamento A11 coincidente com o núcleo subparafascicular magnocelular do tálamo para a amígdala foram descritas no rato por Takada (1993). Este estudo, baseado em injeções de FG envolvendo os núcleos lateral, basolateral e central da amígdala, combinadas à imunofluorescência para $\mathrm{TH}$, destaca a presença freqüente de células duplamente marcadas no núcleo subparafascicular do 
tálamo (cerca de $60 \%$ das células positivas para FG). Na mesma espécie, com a mesma metodologia, e após depósitos de FG envolvendo praticamente toda extensão do complexo amigdalóide, Moriizumi e Leduc-Cross (1992) não puderam confirmar a presença de células duplamente marcadas no núcleo subparafascicular, concluindo que este núcleo não envia projeções dopaminérgicas para a amígdala. Em consonância com as observações de Moriizumi e Leduc-Cross (1992), nossos resultados sugerem que as projeções do núcleo subparafascicular do tálamo para o núcleo amigdalóide central não são dopaminérgicas. Em nosso estudo tampouco foram vistas projeções dopaminérgicas oriundas deste distrito talâmico para os demais componentes da amígdala expandida central e concha do acumbens. Neste contexto, deve ser notado que uma projeção muito modesta do grupo A11 coexistente com a substância cinzenta periventricular foi observada nos nossos casos com injeção nos núcleos amigdalóide central e intersticial lateral da estria terminal (i.e., aproximadamente $2 \%$ do total de células duplamente marcadas vistas nestes casos).

Através da técnica da leucoaglutinina do Phaseolus vulgaris (PHA-L) no rato, foram descritas projeções da zona incerta medial, que contém o grupamento A13, para os núcleos central da amígdala e intersticial lateral da estria terminal (Wagner et al., 1995). A natureza dopaminérgica desta projeção foi sugerida com base em evidências neuroquímicas por Eaton et al. (1994). Estes autores detectaram no rato alterações das concentrações de dopamina ou de um de seus metabólitos, o ácido 3,4-dihidroxifenilacético, no núcleo central da amígdala após lesão eletrolítica ou estimulação elétrica bilateral da zona incerta medial. Projeções dopaminérgicas do grupamento A13 para o núcleo central da amígdala foram recentemente 
identificadas nesta mesma espécie por Cheung et al. (1998) com a técnica de dupla marcação celular, utilizando FG como traçador retrógrado, associado àhibridização in situ para TH. De acordo com Cheung et al., esta projeção é bastante substancial, e, àtítulo co mparativo, mencionam que foi vista uma célula duplamente marcada no A13 para cada seis duplas presentes no A10. Nossos achados diferem frontalmente dos de Cheung et al.. Em nenhum dos sete casos com injeção de FG no núcleo central da amígdala foram vistas aferências significativas provindas do A13 (em média, detectamos uma célula duplamente marcada no A13 para cada 300 duplas no A10). Nossas injeções eram relativamente grandes, porém confinadas ao núcleo amigdalóide central, devendo ser ressaltado que toda extensão deste núcleo foi por nós explorada. A metodologia de Cheung et al. (1998) difere da nossa. Assim, é possível que os neurônios que contém TH sejam mais facilmente visualizados com a técnica de hibridização in situ do que por imunofluorescência, o que acarretaria numa diminuição do número de células que contém TH no A13 visto em nosso material em relação æ̀̀uele visto por Cheung. Como conseqüência, o número de células duplamente marcadas em nossos casos pode ter sido subestimado. Porém, esta hipótese não explica de forma satisfatória a discrepância entre os dados de Cheung et al. (1998) e os nossos. De acordo com nossas estimativas, o número de células retrogradamente marcadas em toda extensão rostrocaudal da zona incerta medial é muito modesto (em média seis células por compartimento), sendo inclusive menor do que o número de células duplamente marcadas contadas por Cheung et al. (onze células em dois cortes representativos de zona incerta medial/A13). Infelizmente, Cheung et al. não mencionam o número total de células retrogradamente marcadas observadas na zona incerta medial. De qualquer forma, 
nossos dados sugerem que, independentemente de sua natureza neuroquímica, a projeção da zona incerta medial para o núcleo amigdalóide central, assim como para os outros componentes da amígdala expandida central, é muito modesta.

Assim, nossos resultados levantam a possibilidade de que as alterações bioquímicas no núcleo central da amígdala após lesão ou estimulação da zona incerta medial, vistas por Eaton et al. (1994), sejam mediadas por vias indiretas. Os seguintes circuitos oligossinápticos poderiam estar envolvidos: 1) a zona incerta medial se projeta para o núcleo horizontal da banda diagonal e para o pálido ventral (Wagner et al., 1995), que aferentam maciçamente a área tegmental ventral (Phillipson, 1979), e esta área, por sua vez, envia projeções dopaminérgicas para o núcleo central da amígdala; 2) a zona incerta medial também se projeta densamente para a substância cinzenta periaquedutal (Wagner et al., 1995), que, de acordo com nossos resultados, constitui uma fonte de aferências dopaminérgicas para o núcleo amigdalóide central.

Nossos dados indicam ainda que os grupamentos A12 e A14, dos núcleos arqueado e periventricular do hipotálamo, respectivamente, não se projetam para amígdala expandida central ou para a concha do núcleo acumbens. Sendo assim, verificamos no presente estudo que a inervação dopaminérgica da amígdala expandida central e da concha do núcleo acumbens pelos grupamentos dopaminérgicos diencefálicos é escassa.

\section{Projeções dos grupamentos dopaminérgicos mesencefálicos}

É consenso na literatura que as projeções dopaminérgicas para a amígdala e para a concha do núcleo acumbens derivam essencialmente da porção dorsal do 
complexo nigral ipsolateral, que inclui a área tegmental ventral, a porção dorsal da substância negra, pars compacta e o campo retrorrubral (Fallon e Moore, 1978; Nauta et al., 1978; Beckstead et al., 1979; Swanson, 1982; Phillipson e Griffiths, 1985; Fuller et al., 1987; Oades e Halliday, 1987; Deutch et al., 1988; Seroogy et al., 1989; Klitenick et al., 1992; Brog et al., 1993; Fallon e Loughlin, 1995). Nossas observações estendem estes resultados, pois mostram que o setor dorsal do complexo nigral é uma fonte importante de aferências dopaminérgicas para o núcleo central da amígdala e para sua extensão rostral, i.e., o contínuo representado pelo núcleo intersticial lateral da estria terminal, amígdala expandida sublenticular e núcleo intersticial do ramo posterior da comissura anterior.

Nossa análise comparativa revela ainda que, em termos quantitativos, o contingente de aferências dopaminérgicas oriundas dos grupamentos mesencefálicos ventrais para a amígdala expandida central e concha do núcleo acumbens varia de acordo com a estrutura inervada (Figs. 27-28). Deste modo, cerca de um terço das células do mesencéfalo ventral que inervam os núcleos central da amígdala, intersticial lateral da estria terminal e amígdala expandida sublenticular são dopaminérgicas; enquanto que de $60 \%$ a $70 \%$ das células do mesencéfalo ventral que aferentam o núcleo intersticial do ramo posterior da comissura anterior ou a concha do acumbens são dopaminérgicas. Além disso, destacamos que os grupamentos A8, A9 e os subnúcleos do A10 se projetam com densidades variáveis para os diferentes componentes da amígdala expandida central e para os subterritórios da concha do acumbens.

Uma projeção dopaminérgica oriunda da porção ventral da substância negra, pars compacta, foi notada apenas para a amígdala expandida sublenticular, sendo 
mais proeminente quanto mais dorsal é o local de injeção. Este quadro é exacerbado no caso 323 (com injeção de FG centrada no globo pálido e acometendo perifericamente a amígdala expandida sublenticular), onde quase $25 \%$ de toda a inervação dopaminérgica provém da porção ventral da substância negra, pars compacta. Em todos os casos com injeção na amígdala expandida sublenticular foi observada uma marcação retrógrada no núcleo subtalâmico, devendo ser ressaltado que a densidade desta se correlaciona com a densidade de marcação na porção ventral da substância negra, pars compacta. Tendo-se em mente que o núcleo subtalâmico representa uma grande fonte de aferências do globo pálido, (ver revisão de Heimer et al., 1995), é reforçada a hipótese de que o espraiamento de FG para o globo pálido possa ter contribuído para a marcação retrógrada vista na porção ventral da substância negra, pars compacta. Lembramos que as fronteiras entre a amígdala expandida sublenticular e o globo pálido são pouco nítidas, havendo embricamento destas duas populações (Grove, 1988a; Alden et al., 1994; Shammah-Lagnado et al., 1996). Também no estudo sistemático das aferências da amígdala expandida sublenticular realizado por Grove (1988a) houve contaminação do globo pálido adjacente, inferida pela presença de neurônios retrogradamente marcados no núcleo subtalâmico.

Projeções da substância cinzenta periaquedutal e núcleo dorsal da rafe

Projeções da substância cinzenta periaquedutal para os diferentes componentes da amígdala expandida central e para o núcleo acumbens tinham sido previamente identificadas em estudos de rastreamento anterógrado (Eberhart et al., 1985; Meller e Dennis, 1991; Rizvi et al., 1991) e retrógrado (Groenewegen et al., 
1980; Weller e Smith, 1982; Grove; 1988a; Brog et al., 1993; Shammah-Lagnado et al., 1999). Em concordância com estes achados, nossas observações indicam que suas colunas lateral e ventrolateral inervam densamente os núcleos amigdalóide central, intersticial lateral da estria terminal e a amígdala expandida sublenticular e em grau bem menor o núcleo intersticial do ramo posterior da comissura anterior e a concha medial do acumbens.

A substância cinzenta periaquedutal, como já mencionado, contém células presumivelmente dopaminérgicas, i.e., que contém TH e que não expressam a enzima dopamina-ß-hidroxilase (Köhler e Goldstein, 1984; Miachon et al., 1984; Charara e Parent, 1998). De acordo com a terminologia proposta por Hökfelt et al. (1984), estas células pertencem ao grupamento A10dc, ou seja, representam uma extensão dorsal e caudal do grupamento A10.

Um dos achados de maior interesse do presente estudo foi demonstrar uma projeção muito substancial, e até então não suspeitada, do grupo A10dc para os núcleos central da amígdala e intersticial lateral da estria terminal. De fato, este grupamento contém em média $45 \%$ do total de células duplamente marcadas identificadas em casos com injeção nos núcleos central da amígdala e intersticial lateral da estria terminal.

Apesar da substância cinzenta periaquedutal inervar densamente a amígdala expandida sublenticular (Grove, 1988a; Meller e Dennis, 1991; presentes resultados), de acordo com nossas observações, apenas uma pequena parte destas projeções se origina do grupo A10dc. A contribuição pouco significativa do grupamento A10dc para a inervação do núcleo intersticial do ramo posterior da comissura anterior e da concha do núcleo acumbens se coaduna com o pequeno 
contingente de projeções oriundas da substância cinzenta periaquedutal para estas duas estruturas (Eberhart et al., 1985; Meller e Dennis, 1991; Brog et al., 1993; Shammah-Lagnado et al., 1999). Deste modo, o padrão de inervação dopaminérgica do corredor ventral da amígdala expandida, formado pelo núcleo intersticial do ramo posterior da comissura anterior e amígdala expandida sublenticular, e também o padrão de inervação da concha do acumbens, se assemelham, uma vez que o grupo A10dc não aferenta de maneira significativa tais estruturas.

O núcleo dorsal da rafe, àsemelhança do subst ância cinzenta periaquedutal, contém células presumivelmente dopaminérgicas ( $\mathrm{TH}$-ir), e que correspondem ao grupamento A10dc (Hökfelt et al., 1984). As células TH-ir, de acordo com evidências em macaco, não ocupam o mesmo território do núcleo dorsal da rafe que as células serotoninérgicas (Charara e Parent, 1998), estando as primeiras localizadas medialmente e as últimas lateralmente no núcleo dorsal da rafe. Este fato sugere fortemente que as células dopaminérgicas do dorsal da rafe não coexistam com as células serotoninérgicas.

Estudos prévios relatam, através de técnicas de rastreamento anterógrado, projeções do núcleo dorsal da rafe para os núcleos central da amígdala e intersticial da estria terminal, amígdala expandida sublenticular e núcleo acumbens (Vertes, 1991), e, através de técnicas de rastreamento retrógrado, para o núcleo intersticial da estria terminal (Weller e Smith, 1991), amígdala expandida sublenticular (Grove, 1988a), núcleo intersticial do ramo posterior da comissura anterior (ShammahLagnado et al., 1999) e núcleo acumbens (Groenewegen et al., 1980; Brog et al., 1993). Além de confirmar estes achados, nossas observações indicam que o grupo A10dc do núcleo dorsal da rafe contribui de forma significativa para a inervação dos 
núcleos central da amígdala e intersticial lateral da estria terminal, contendo aproximadamente $15 \%$ do total de células duplamente marcadas vistas nestes casos. Projeções ascendentes oriundas de células TH-ir do núcleo dorsal da rafe e suas imediações para o estriado dorsal, septo lateral, córtex pré-frontal medial e núcleo acumbens no rato, mas não para a amígdala, já haviam sido descritas no rato por Stratford e Wirtshafter (1990). Em contraposição a estes autores, vimos uma escassa projeção do grupo A10dc para o núcleo acumbens. Apesar de não especificarem o distrito do acumbens injetado, no caso representativo ilustrado por Stratford e Wirtshafter (1990) o sítio de injeção está localizado mais lateralmente do que em nossos casos e envolve também o cerne do núcleo acumbens, o que possivelmente explica a diferença de resultados obtidos. Lembramos que a distinção entre o cerne e a concha do acumbens é primordial, tendo-se em vista as diferenças hodológicas e funcionais das duas divisões deste núcleo, extensamente abordadas em diferentes trabalhos (Heimer et al., 1991; Zahm e Brog, 1992; Wu et al., 1999).

Projeções recíprocas do núcleo amigdalóide central para a substância cinzenta periaquedutal e para o núcleo dorsal da rafe foram descritas no rato (Rizvi et al., 1991; Wallace et al., 1992) e no macaco (Price e Amaral, 1981). Wallace et al. (1992) ressaltam inclusive que terminais axônicos do núcleo amigdalóide central foram vistos junto a células TH-ir da substância cinzenta periaquedutal e núcleo dorsal da rafe.

Natureza neuroquímica das projeções da substância cinzenta periaquedutal e do núcleo dorsal da rafe para o núcleo central da amígdala 
Projeções do grupamento A10dc (núcleo dorsal da rafe e substância cinzenta periaquedutal) para a amígdala expandida central não haviam sido previamente relatadas na literatura. As células do grupamento A10dc são imunorreativas ao anticorpo anti-TH mas não ao anticorpo anti-dopamina $\beta$-hidroxilase. Em função destas características, são geralmente consideradas dopaminérgicas. Evidências recentes sugerem, entretanto, que parte das células $\mathrm{TH}$-ir da substância cinzenta periaquedutal contém a L-3,4-dihidroxifenilalanina (L-DOPA), e não a dopamina, como produto final (Misu et al., 1996). Nestes neurônios, a L-DOPA funcionaria não como um precursor das catecolaminas, mas como um neurotransmissor e/ou neuromodulador. Os neurônios L-DOPAérgicos podem ser reconhecidos pelos seguintes critérios: 1) apresentam imunorreatividade ao anticorpo anti-TH, mas não ao anticorpo anti-aminoácido aromático descarboxilase (AADC, a enzima que converte a L-DOPA em dopamina); 2) apresentam imunorreatividade ao anticorpo anti-L-DOPA, mas não ao anticorpo anti-dopamina. Grupos de neurônios presumivelmente L-DOPAérgicos (TH-positivos, L-DOPA-positivos, AADC-negativos e dopamina-negativos) foram identificados na substância cinzenta periaquedutal e em vários outros territórios, incluindo o núcleo interfascicular da área tegmental ventral, neurônios aferentes primários do gânglio nodoso (ver revisão de Misu et al., 1996), núcleos hipotalâmicos (Okamura et al., 1988; Mons et al., 1990; Tison et al., 1990) e complexo dorsal do vago (Tison et al., 1989). Terminações nervosas LDOPAérgicas foram vistas no núcleo central da amígdala do gato (Kitahama et al., 1988).

Assim, com o objetivo de comprovar a natureza dopaminérgica da projeção TH-positiva do grupamento A10dc para o núcleo central da amígdala, casos com 
injeção de FG no núcleo central da amígdala foram processados usando um anticorpo específico para dopamina.

A análise do material processado por imunofluorescência com anticorpo para dopamina permitiu comprovar que as projeções do núcleo dorsal da rafe e da substância cinzenta periaquedutal para o núcleo central da amígdala são em parte dopaminérgicas. Deve entretanto ser ressaltado que em média $20 \%$ das células positivas para FG na substância cinzenta periaquedutal, e em média $8 \%$ das observadas no núcleo dorsal da rafe, eram duplamente marcadas. Lembramos que, nos casos processados para $\mathrm{TH}$, esta proporção é de cerca de $60 \%$ na substância cinzenta periaquedutal e cerca de $45 \%$ no núcleo dorsal da rafe. Algumas hipóteses podem ser levantadas para explicar que, nos casos processados para dopamina, a proporção de células duplamente marcadas na substância cinzenta periaquedutal e no núcleo dorsal da rafe era significativamente menor do que nos casos processados para TH. A visualização do número total de corpos celulares DA-ir foi sem dúvida prejudicada pela presença de autofluorescência no tecido, provocada pelo alto teor de glutaraldeído utilizado para fixar o cérebro. Outra possibilidade é que a maior espessura dos cortes obtidos em vibrátomo $(50 \mu \mathrm{m})$ em relação aos obtidos em micrótomo de congelação $(20 \mu \mathrm{m})$, pode ter contribuído para que o anticorpo anti-dopamina não entrasse em contato com os elementos dopaminérgicos contidos em toda profundidade da secção, apesar do tratamento com Triton X-100. Finalmente, pode haver ainda uma diferença de sensibilidade e penetrância entre os anticorpos anti-dopamina e anti-TH. Isto poderia justificar a proporção um pouco menor de neurônios DA-ir em relação aos neurônios TH-ir no campo retrorrubral após análise comparativa de um caso processado com anticorpo anti-dopamina e 
outro com anti-TH. Entretanto, no núcleo dorsal da rafe e na substância cinzenta periaquedutal, a proporção de células DA-ir em relação ̀̀ TH -ir é drasticamente menor, chegando a ser de 30 a $45 \%$ da quantidade de células $\mathrm{TH}$-ir nestas duas estruturas. Estes resultados sugerem que não se trata apenas de limitações inerentes ao uso do anticorpo anti-dopamina, pois estas afetariam igualmente a visualização da imunorreatividade nos diferentes territórios cerebrais. Assim, é possível que parte das células TH-ir da substância cinzenta periaquedutal e do núcleo dorsal da rafe usem L-DOPA, e não dopamina, como produto final.

A informação de maior impacto indicando que a L-DOPA existe como produto final, e não apenas como precursor da dopamina, no sistema nervoso repousa sobre achados imunohistoquímicos. Entretanto, não se sabe ao certo qual a porcentagem de L-DOPA que pode ser identificada pelo método de imunohistoquímica atual baseado na fixação do tecido pelo glutaraldeído. Assim, apesar da L-DOPA ser liberada por impulsos elétricos em amostras de estriado de ratos, e de ter sido identificada em experimentos de microdiálise realizados no estriado de ratos conscientes (ver revisão de Misu et al., 1996), a marcação dos terminais LDOPAérgicos do estriado por imunoperoxidase é muito fraca (Kitahama et al., 1988; Mons et al., 1988).

Algumas evidências indicam que a L-DOPA de determinados territórios parece funcionar como neurotransmissor, uma vez que possui um sistema de transporte transmembrana próprio, uma enzima que a degrada (a catecol-o-metil tranferase), e sua liberação pode ser inibida pela tetrodotoxina e pela deprivação do íon cálcio. A L-DOPA parece ainda possuir um mecanismo de transporte e armazenamento semelhante a vesículas nos nervos terminais (ver revisão de Misu 
et al., 1996). Foi demonstrado também que a via L-DOPAérgica do hipotálamo posterior para o núcleo rostroventrolateral do bulbo $(R V L)$ está relacionada com a resposta de aumento da freqüência cardíaca e pressão arterial. A estimulação desta via causa aumento da L-DOPA, e não de catecolaminas, no RVL, onde se liga a sítios receptores específicos, ativando sítios pressores do RVL em ratos anestesiados (Nishihama et al., 1999).

Projeções da área tegmental ventral

Dentre os grupamentos do mesencéfalo ventral, o A10 detém a maior proporção de células duplamente marcadas em todos os casos. Do total de células duplamente marcadas encontradas, cerca de $30 \%$ estão no A10 nos casos com injeção nos núcleos central da amígdala e intersticial lateral da estria terminal, cerca de $60 \%$ nos casos com injeção na amígdala expandida sublenticular, e pouco mais de $70 \%$ nos casos com injeção no núcleo intersticial do ramo posterior da comissura anterior. Esta proporção aumenta para aproximadamente $90 \%$ nos casos com injeção na concha do núcleo acumbens, sendo semelhante à encontrada por Swanson (1982). Grande parte das células TH-ir da área tegmental ventral que se projetam para o núcleo acumbens e para os núcleos central e basolateral da amígdala contém também colecistoquinina (CCK) (Seroogy et al., 1989). Neste estudo, Seroogy et al. notaram que aproximadamente $60-70 \%$ dos neurônios da área tegmental ventral que inervam o núcleo acumbens, e cerca de $50 \%$ dos que inervam os núcleos central e basolateral da amígdala, são contém TH e CCK. Um estudo morfométrico de Tan et al. (1995) descreve ainda que as células do mesencéfalo ventral que se projetam para a concha do núcleo acumbens são de 
tamanho pequeno a médio (10 $\mu \mathrm{m}$ de diâmetro, em média), sendo menores do que as que se projetam para o cerne e o pólo rostral do núcleo acumbens (12 $\mu \mathrm{m}$ de diâmetro, em média). Outro estudo do mesmo grupo de autores (Tan et al., 1999), reporta que cerca de $35 \%$ das células da área tegmental ventral que aferentam a concha do núcleo acumbens são também imunorreativas ao anticorpo anticalbindina-D 28kD.

Diversos estudos demonstraram projeções da área tegmental ventral para os núcleos acumbens, central da amígdala, intersticial da estria terminal, amígdala expandida sublenticular e núcleo intersticial do ramo posterior da comissura anterior através de técnicas de rastreamento anterógrado (Fallon e Moore, 1978; Beckstead et al., 1979; ver revisão de Oades e Halliday, 1987) e retrógrado (Fallon e Moore, 1978; Groenewegen et al., 1980; Newman e Winans, 1980; Kalivas et al., 1985; Phillipson e Griffiths, 1985; Grove, 1988a; Klitenick et al., 1992; Brog et al., 1993; Shammah-Lagnado et al., 1999).

Os componentes da amígdala expandida central recebem inervação dopaminérgica que se origina em proporção e localização distintas, levando-se em conta os diversos núcleos que compõem a área tegmental ventral (Figs. 7, 11, 15, 19, 24). Enquanto o núcleo parabraquial pigmentoso concentra a maior parte de células TH-ir que se projetam para a amígdala expandida sublenticular (cerca $40 \%$ do total de células duplamente marcadas encontradas) e para o núcleo intersticial do ramo posterior da comissura anterior (cerca de 50\%), os núcleos amigdalóide central e intersticial lateral da estria terminal recebem projeções igualmente densas dos núcleos parabraquial pigmentoso e linear caudal da rafe, que em conjunto perfazem $20 \%$ do total de células duplamente marcadas vistas em cada um destes casos. Foi 
constatado em nosso material que projeções dopaminérgicas oriundas do núcleo parabraquial pigmentoso para os núcleos central da amígdala, intersticial lateral da estria terminal e intersticial do ramo posterior da comissura anterior se originam principalmente do seu setor dorsolateral. Esta última observação está de acordo com os resultados ilustrados por Klitenick et al. (1992) após injeção de FG no núcleo intersticial do ramo posterior da comissura anterior.

Nossos resultados sugerem ainda que as projeções dopaminérgicas para a concha do núcleo acumbens obedecem a uma topografia dorsoventral invertida, confirmando observações anteriores em rato (Brog et al., 1993) (Figs. 21, 25-26). Os setores ventrais do grupamento A10, i.e., os núcleos interfascicular e paranigral, enviam projeções dopaminérgicas para os setores dorsais da concha do acumbens, enquanto que setores dorsais do A10 inervam mais pronunciadamente setores ventrais da concha do acumbens. Em particular, os núcleos interfascicular, linear caudal da rafe, paranigral, e parabraquial pigmentoso contribuem em igual proporção para a inervação dopaminérgica da região dorsomedial da concha do acumbens (caso 310). Por outro lado, a porção ventral da concha do acumbens (caso 318) é inervada predominantemente pelo núcleo parabraquial pigmentoso (cerca de $60 \%$ do total de células duplamente marcadas encontradas no caso), em menor grau pelos núcleos paranigral e linear caudal da rafe, e pouco pelo núcleo interfascicular. Estes resultados são coerentes com os de Phillipson e Griffiths (1985), que observaram densa marcação retrógrada nos núcleos interfascicular e paranigral após injeção na porção caudomedial da concha do acumbens, e no núcleo parabraquial pigmentoso após injeção na porção caudoventrolateral da concha do acumbens, concluindo que estas projeções seguem uma organização 
topográfica dorsoventral invertida. Este padrão topograficamente organizado pode ser identificado também no núcleo parabraquial pigmentoso, uma vez que sua região ventral inerva preferencialmente o setor dorsomedial da concha do acumbens.

Uma organização topográfica mediolateral direta das projeções do A10 para o núcleo acumbens foi também identificada por Phillipson e Griffiths (1985) e por Brog et al. (1993). Observamos que quando a injeção de FG está localizada em setores mais laterais da concha do acumbens (caso 318), as células retrogradamente marcadas tendem a se concentrar mais lateralmente ao nível da porção caudal do núcleo parabraquial pigmentoso, confirmando a organização topográfica mediolateral direta destas projeções. Em consonância com nossos resultados, Kalivas et al. (1985) mostraram marcação retrógrada no setor lateral do núcleo parabraquial pigmentoso após injeção na porção do núcleo acumbens localizada lateralmente à comissura anterior. Em contraposição, nenhuma organização topográfica destas projeções foi vista no estudo de Swanson (1982), que obteve injeções em diferentes partes do núcleo acumbens.

A região do grupamento A10 correspondente ao núcleo paranigral inerva muito modestamente a amígdala expandida central, mas participa de forma importante (entre $15 \%$ e $25 \%$ do total de células duplamente marcadas) na inervação da concha do núcleo acumbens, em especial, do seu setor dorsal. Além disso, as projeções do núcleo paranigral seguem uma topografia dorsoventral invertida, onde sua porção dorsal inerva preferencialmente a parte ventral da concha do núcleo acumbens (Figs. 25-26).

Da mesma maneira, o núcleo interfascicular, que está ventralmente localizado no grupamento A10, apresenta uma contribuição mais substancial na inervação das 
porções dorsais da concha do núcleo acumbens (entre 13\% e 25\% do total de células duplamente marcadas vistas nestes casos), mas pouco expressiva na inervação sua porção ventral, bem como dos componentes da amígdala expandida central.

Finalmente, as projeções dopaminérgicas oriundas dos núcleos linear rostral e caudal da rafe para a amígdala expandida sublenticular e para o núcleo intersticial do ramo posterior da comissura anterior são moderadas em intensidade e equivalentes em proporção (Figs. 15 e 19). A projeção do núcleo linear rostral da rafe para a porção central amígdala expandida sublenticular já havia sido demonstrada por Grove (1988a), porém não havia ainda sido relatado que esta projeção se originava em parte de células dopaminérgicas. Klitenick et al. (1992) observaram que injeções de FG na região do núcleo intersticial do ramo posterior da comissura anterior resulta em modesta marcação retrógrada nos núcleos da linha média da área tegmental ventral. Por outro lado, o núcleo linear caudal da rafe, e não o núcleo linear rostral da rafe, envia projeções dopaminérgicas para os núcleos central da amígdala, intersticial lateral da estria terminal e, de maneira mais intensa, para a concha do núcleo acumbens.

Em suma, distinguimos três padrões distintos de projeções dopaminérgicas da área tegmental ventral para os componentes da amígdala expandida central e concha do acumbens. Os núcleos central da amígdala e intersticial lateral da estria terminal, de maneira semelhante, recebem projeções dopaminérgicas em proporções equivalentes dos núcleos parabraquial pigmentoso e linear caudal da rafe, enquanto que a amígdala expandida sublenticular e o núcleo intersticial do ramo posterior da comissura anterior têm suas aferências dopaminérgicas oriundas 
principalmente do núcleo parabraquial pigmentoso, e em menor grau, dos núcleos linear rostral e caudal da rafe. Já os subterritórios da concha do acumbens recebem projeções dopaminérgicas da área tegmental ventral de acordo com uma topografia dorsoventral invertida, onde setores ventrais do A10 (i.e., os núcleos interfascicular e paranigral) contribuem de forma mais pronunciada para a inervação dopaminérgica da região dorsal da concha do núcleo acumbens, ao passo que setores dorsais do A10 inervam territórios ventrais da concha do acumbens.

Apesar de uma semelhança entre a concha do acumbens e a amígdala expandida central ter sido cogitada com base em evidências neuroquímicas (Heimer, 1991), estudos mais detalhados comprovam que ambos constituem parte de sistemas neurais segregados (Zahm, 1998; Zahm et al., 1999). Nossos dados reforçam esta idéia, uma vez que os padrões de inervação da concha do núcleo acumbens e da amígdala expandida central são distintos entre si. Entretanto, uma interação entre estes dois sistemas pode existir. A amígdala expandida poderia, através de suas projeções para o hipotálamo lateral e tronco cerebral (substância cinzenta periaquedutal, núcleo do trato solitário e área parabraquial) modular a informação que chega ao núcleo acumbens, e conseqüentemente o sistema estriadopalidal-talamocortical (Zahm, 1998). É possível também que a interação entre estes dois sistemas seja bidirecional, pois a região da área tegmental ventral que se projeta para a amígdala expandida central (i.e., os núcleos parabraquial pigmentoso e linear caudal da rafe, visto em nosso estudo), recebe projeções diretas da concha do núcleo acumbens (Zahm, 1998).

Projeções do campo retrorrubral 
Projeções do campo retrorrubral para amígdala expandida central e o núcleo acumbens foram descritas no rato por Deutch et al. (1988) com a técnica do PHA-L, e por diferentes autores com técnicas de rastreamento retrógrado (Groenewegen et al., 1980; Swanson, 1982; Kalivas et al., 1985; Phillipson e Griffiths, 1985; Grove, 1988a; Lynd-Balta e Haber, 1994; Brog et al., 1993). No acumbens, as fibras retrorrubrais evitam o setor dorsomedial da concha, fato também substanciado em experimentos de rastreamento retrógrado (Brog et al., 1993; presentes resultados). Deutch et al. (1988) demonstraram ainda que as projeções retrorrubrais para os núcleos intersticial lateral da estria terminal, central da amígdala, acumbens e setores ventrolaterais do estriado incluindo o núcleo intersticial do ramo posterior da comissura anterior se originam em parte das células dopaminérgicas do A8. Nossos resultados confirmam as observações destes autores e indicam que o A8 contribui de forma relativamente modesta para a inervação dopaminérgica da amígdala expandida central e da concha do acumbens (de $2 \%$ a $13 \%$ do número total de células duplamente marcadas foram identificadas no campo retrorrubral). É notável que a grande maioria dos neurônios retrorrubrais retrogradamente marcados após injeção nos núcleos amigdalóide central, intersticial lateral da estria terminal e corredor sublenticular não é duplamente marcada, ao passo que os neurônios retrorrubrais duplamente marcados predominam após injeção no núcleo intersticial do ramo posterior da comissura anterior e concha do acumbens. Uma projeção predominantemente dopaminérgica, oriunda do retrorrubral para o acumbens, foi vista também por Kalivas et al. (1985).

Uma organização topográfica das projeções retrorrubro-telencefálicas fora previamente notada, de forma que as porções mais mediais do A8 inervam 
estruturas mediais (por exemplo, acumbens), enquanto que estruturas laterais (amígdala e caudado-putâmen) são inervadas por regiões laterais do A8 (Deutch et al., 1988). Nossas observações corroboram tal organização, uma vez que a concha ventromedial do acumbens é inervada pelo setor medial do campo retrorrubral, enquanto que o componente mais medial da amígdala expandida central i.e., o núcleo intersticial lateral da estria terminal, recebe inervação tanto das porções mediais quanto laterais do campo retrorrubral, e as porções mais laterais da amígdala expandida central são inervadas pelo setor lateral do retrorrubral.

As conexões entre a amígdala expandida central e o complexo nigral exibem certa reciprocidade, onde o principal alvo das projeções amigdalófugas é o campo retrorrubral e a porção lateral da substância negra, pars compacta (Gonzalez e Chesselet, 1990; Alheid et al., 1996; Zahm et al., 1999), entretanto, as eferências do complexo nigral para a amígdala expandida central se originam primariamente da área tegmental ventral e do campo retrorrubral (Shammah-Lagnado et al., 1999, presentes observações).

\section{Projeções da substância negra}

Como mencionado anteriormente, a inervação nigral da amígdala expandida central e da concha do acumbens deriva essencialmente da porção dorsal da substância negra, pars compacta, e as projeções oriundas de sua porção ventral parecem ter como alvo a região do globo pálido adjacente àamígdala expandida sublenticular. A porção dorsal da substância negra, pars compacta, emite um pequeno contingente de projeções dopaminérgicas para a amígdala expandida central e concha do acumbens. Estudos anteriores identificaram projeções modestas 
da substância negra, pars compacta para os núcleos central da amígdala (Fallon e Moore, 1978; Deutch et al., 1988), amígdala expandida sublenticular (Grove, 1988a) e núcleo intersticial do ramo posterior da comissura anterior (Fuller et al., 1987; Klitenick et al., 1992), sem contudo, confirmarem sua natureza dopaminérgica.

Projeções muito modestas da substância negra, pars lateralis, para o núcleo amigdalóide central foram também identificadas em nosso estudo. Moriizumi et al. (1992) tinham previamente demonstrado que os núcleos central e basolateral da amígdala são inervados pela porção ventromedial da substância negra, pars lateralis, onde estão localizadas as células $\mathrm{TH}$-ir, enquanto que aferências do colículo inferior se origina de neurônios gabaérgicos situados na porção dorsolateral da substância negra, pars lateralis. Todas as células da substância negra, pars lateralis, e quase todas as da pars compacta, que se projetam para os núcleos central e basolateral da amígdala contém TH e CCK (Seroogy et al., 1989).

\section{Considerações funcionais}

As projeções dopaminérgicas para amígdala expandida central e concha do núcleo acumbens podem ser moduladas pelos diferentes sistemas que deságuam principalmente na área tegmental ventral e no conjunto substância cinzenta periaquedutal/núcleo dorsal da rafe. Dentre os sistemas que modulam tanto a área tegmental ventral quanto o conjunto substância cinzenta periaquedutal/núcleo dorsal da rafe estão os sistemas límbico e motor.

As aferências límbicas comuns àárea tegmental ventral e à substância cinzenta periaquedutal/núcleo dorsal da rafe se originam em grande parte do hipotálamo lateral, da área pré-óptica lateral, e de componentes da amígdala 
expandida (núcleos central da amígdala, intersticial da estria terminal e amígdala expandida sublenticular) (Phillipson, 1979; Beitz, 1982; Peyron et al., 1998). A área tegmental ventral e a substância cinzenta periaquedutal/núcleo dorsal da rafe também recebem um grande contingente de projeções oriundas do córtex pré-frontal e da habênula lateral. A habênula lateral é por si um ponto de convergência de informações límbicas, originadas principalmente no hipotálamo, e motoras dos núcleos da base, provindas do núcleo entopeduncular (Herkenham e Nauta, 1977). As informações dos sistemas límbico e motor podem ainda alcançar a área tegmental ventral indiretamente, através do núcleo tegmental pedúnculo pontino, que integra projeções do hipotálamo lateral, da amígdala expandida sublenticular e do núcleo entopeduncular (Phillipson, 1979).

As aferências motoras diretas da área tegmental ventral, por sua vez, são oriundas de estruturas dos núcleos da base que compõem os sistemas estriadopalidal ventral (núcleo acumbens e pálido ventral) e dorsal (globo pálido interno, no macaco, ou seu análogo, o núcleo entopeduncular no rato) (Phillipson, 1979). A substância cinzenta periaquedutal e o núcleo dorsal da rafe também são modulados diretamente pelos sistemas estriadopalidal dorsal e ventral, através de projeções que se originam respectivamente da substância negra, pars reticulata, e do pálido ventral (Beitz, 1982; Peyron et al., 1998).

A área tegmental ventral e o conjunto substância cinzenta periaquedutal/núcleo dorsal da rafe são, portanto, modulados por uma constelação de estruturas comuns que fazem parte dos sistemas límbico e motor. Além destas, outras estruturas dos sistemas límbico e motor se projetam preferencialmente para a área tegmental ventral ou para a substância cinzenta periaquedutal/núcleo dorsal da 
rafe. Assim, o núcleo acumbens se projeta preferencialmente para a área tegmental ventral (Phillipson, 1979), enquanto que as regiões tuberal e perifornicial do hipotálamo inervam mais densamente a substância cinzenta periaquedutal (Beitz, 1982) e o núcleo dorsal da rafe (Peyron et al., 1998).

Em suma, as informações do hipotálamo, amígdala expandida, córtex préfrontal e sistemas estriadopalidal ventral e dorsal, integradas na área tegmental ventral ou na substância cinzenta periaquedutal/núcleo dorsal da rafe, podem ser importantes na modulação das projeções dopaminérgicas para amígdala expandida central e para a concha do núcleo acumbens. Deve ser ressaltado que experimentos analisados a nível de microscopia eletrônica são necessários para se identificar com exatidão as vias neurais que agem diretamente sobre as células dopaminérgicas da área tegmental ventral, substância cinzenta periaquedutal e núcleo dorsal da rafe, modulando as projeções dopaminérgicas para a divisão central da amígdala expandida e concha do núcleo acumbens. 


\section{CONCLUSÕES}

Os presentes resultados levam a uma nova visão da inervação dopaminérgica da amígdala expandida central e da concha do núcleo acumbens uma vez que:

1) Os padrões de inervação dopaminérgica dos pólos rostral e caudal da amígdala expandida central (i.e., núcleos intersticial lateral da estria terminal e central da amígdala) são semelhantes entre si no que diz respeito à localização topográfica e à densidade das projeções de cada um dos grupamentos dopaminérgicos que os aferentam. A inervação dopaminérgica dos pólos rostral e caudal da amígdala expandida central se origina em igual proporção dos grupamentos A10dc (núcleo dorsal da rafe e substância cinzenta periaquedutal) e A8/A10.

2) Usando-se um anticorpo específico para dopamina comprovou-se que parte da projeção do grupamento A10dc para o núcleo central da amígdala é de fato dopaminérgica.

3) A inervação dopaminérgica do corredor ventral da amígdala expandida (i.e., amígdala expandida sublenticular e núcleo intersticial do ramo posterior da comissura anterior) e da concha do núcleo acumbens se origina quase exclusivamente dos grupamentos A8/A9/A10, diferindo do padrão de inervação dopaminérgica dos pólos rostral e caudal da amígdala expandida central.

4) Os subterritórios da concha do núcleo acumbens recebem projeções dopaminérgicas da porção dorsal dos grupamentos A8/A9/A10 de acordo com uma organização topográfica médiolateral direta e dorsoventral invertida. 
5) A divisão central da amígdala expandida, bem como a concha do núcleo acumbens, não recebem projeções dopaminérgicas significativas dos grupamentos diencefálicos A11, A12, A13, A14. 


\section{REFERÊNCIAS BIBLIOGRÁFICAS}

1. Alden, M., Besson, J.M., Bernard, J.F. (1994) Organization of the efferent projections from the pontine parabrachial area to the bed nucleus of the stria terminalis and neighboring regions: a PHA-L study in the rat. J. comp. Neurol. 341, 289- 314.

2. Alheid, G.F., de Olmos, J., Beltramino, C.A. (1995) Amygdala and extended amygdala. In The Rat Nervous System, $2^{\text {nd }}$ edn (ed. Paxinos, G.), pp. 495578. Academic Press, San Diego.

3. Alheid, G.F., Shammah-Lagnado, S.J., Beltramino, C.A., Yang, M., Miselis, M.M., de Olmos, J.S., Heimer, L. (1996) Efferent connections of a dopaminerich lateral wing of the rat extended amygdala. Soc. Neurosci. Abstr. 22, 2049.

4. Alheid, G.F., Beltramino, C.A., de Olmos, J.S., Forbes, M.S., Swanson, D.J., Heimer, L. (1998) The neural organization of the supracapsular part of the stria terminalis in the rat: the dorsal component of the extended amygdala. Neuroscience 84, 967-996.

5. Alheid, G.F., Shammah-Lagnado, S.J., Beltramino, C.A. (1999) The interstitial nucleus of the posterior limb of the anterior commissure: a novel layer of the central division of the extended amygdala. Ann. N.Y. Acad. Sci. 877, 645-654.

6. Beckstead, R.M., Domesick, V.B., Nauta, W.J.H. (1979) Efferent connections of the substantia nigra and ventral tegmental area in the rat. Brain Res. 175, 191-217.

7. Beitz, A.J. (1982) The organization of afferent projections to the midbrain periaqueductal gray of the rat. Neuroscience 7, 133-159.

8. Betancur, C., Rostène, W., Bérod, A. (1997) Chronic cocaine increases neurotensin gene expression in the shell of the nucleus accumbens and in discrete regions of the striatum. Mol. Brain Res. 44, 334-340. 
9. Björklund, A., Lindvall, O. (1984) Dopamine-containing systems in the CNS. In Handbook of Chemical Neuroanatomy (eds. Björklund, A., Lindvall, O.). Vol 2, Classical Transmitters in the CNS, Part 1, pp. 55-122. Elsevier, Amsterdam.

10.Brog, J.S., Salyapongse, A., Deutch, A.Y., Zahm, D.S. (1993) The patterns of afferent innervation of the core and shell in the "accumbens" part of the rat ventral striatum: immunohistochemical detection of retrogradely transported Fluoro-Gold. J. comp. Neurol. 338, 225-78.

11. Brown, V.J., Latimer, M.P., Winn, P. (1996) Memory for the changing cost of a reward is mediated by the sublenticular extended amygdala. Brain Res. Bull. 39, $163-170$.

12. Caroleo, M.C., Arbirio, M., Franscesco, P., Pulvirenti, L., Garaci, E., Nistico, G. (1998) Cocaine induced $T$ cell proliferation in the rat: role of amygdala dopamine D1 receptors. Neurosci. Lett. 256, 61-64.

13. Charara, A., Parent, A. (1998) Chemoarchitecture of the primate dorsal raphe nucleus. J. Chem. Neuroanat. 72, 111-127.

14. Cheung, S., Ballew, J.R., Moore, K.E., Lookingland, K.J. (1998) Contribution of dopamine neurons in the medial zona incerta to the innervation of the central nucleus of the amygdala, horizontal diagonal band of Broca and hypothalamic paraventricular nucleus. Brain Res. 808, 175-181.

15. Dahlström, A., Fuxe, K. (1964) Evidence for the existence of monoaminecontaining neurons in the central nervous system. I. Demonstration of monoamines in the cell bodies of brain stem neurons. Acta physiol. scand. 62, suppl. 232, 1-55.

16. Davis, M., Rainnie, D., Cassel, M. (1994) Neurotransmission in the rat amygdala related to fear and anxiety. Trends Neurosci. 17, 208-214.

17.de Olmos, J., Alheid, G.F., Beltramino, C.A. (1985) Amygdala. In The rat nervous system (ed. Paxinos, G.), pp 223-334. Academic Press. 
18.de Olmos, J.S., Heimer, L. (1999) The concepts of ventral striatopallidal system and extended amygdala. Ann. N.Y. Acad. Sci. 877, 1-32.

19.Deutch, A.Y., Goldstein, M., Baldino, F., Roth, R.H. (1988) Telencephalic projections of the A8 dopamine cell group. Ann. N.Y. Acad. Sci. 537, 27-50.

20.Deutch, A.Y., Bourdelais, A.J., Zahm, D.S. (1993) The nucleus accumbens core and shell: accumbal compartments and their functional attributes. In Limbic Motor Circuits and Neuropsychiatry (eds. Kalivas, P.W., Barnes, C.D.), pp. 45-88. CRC Press, Boca Raton.

21.Diaz, J., Lévesque, D., Griffon, M., Lammers, C.H., Martres, M.P., Sokoloff, P., Schwartz, J.C. (1994) Opposing roles for dopamine D2 and D3 receptors on neurotensin mRNA expression in nucleus accumbens. Eur. J. Neurosci. 6, 1384-1387.

22. Di Chiara, G., Tanda, G., Bassareo, V., Pontieri, F., Acquas, E., Fenu, S., Cadoni, C., Carboni, E. (1999) Drug addiction as a disorder of associative learning. Role of nucleus accumbens shell/extended amygdala dopamine. Ann. N.Y. Acad. Sci. 877, 461-485.

23.Eaton, M.J., Wagner, C.K., Moore, K.E., Lookingland, K.J. (1994) Neurochemical identification of A13 dopaminergic neuronal projections from the medial zona incerta to the horizontal limb of the diagonal band of Broca and the central nucleus of the amygdala. Brain Res. 659, 201-207.

24. Eberhart, J.A., Morrell, J.I., Krieger, M.S., Pfaff, D.W. (1985) An autoradiographic study of the projections ascending from midbrain central gray, and from the region lateral to it, in the rat. J. comp. Neurol. 241, 285-310.

25.Epping-Jordan, M.P., Markou, A., Koob, G.F. (1998) The dopamine D1 receptor antagonist $\mathrm{SCH} 23390$ injected into dorsolateral bed nucleus of the stria terminalis decreased cocaine reiforcement in the rat. Brain Res. 784, 105-115. 
26. Fallon, J.H., Moore, R.Y. (1978) Catecholamine innervation of the basal forebrain. IV. Topography of the dopamine projection to the basal forebrain and neostriatum. J. comp. Neurol. 180, 545-580.

27. Fallon, J.H., Loughlin, S.E. (1995) Substantia nigra. In The Rat Nervous System, $2^{\text {nd }}$ edn (ed. Paxinos, G.), pp. 215-237. Academic Press, San Diego.

28. Freedman, L.J., Cassel, M.D. (1994) Distribution of dopaminergic fibers in the central division of the extended amygdala of the rat. Brain Res. 633, 243-252.

29. Fuller, T.A. Russchen, F.T., Price, J.L. (1987) Sources of presumptive glutamatergic/aspartergic afferents to the rat ventral striatopallidal region. $J$. comp. Neurol. 258, 317-338.

30.Gelsema, A.J., Copeland, N.E., Drolet, G., Bachelard, H. (1993) Cardiovascular effects of neuronal activation of the extended amygdala. Brain Res. 626, 156-166.

31. Gonzalez, C., Chesselet, M.F. (1990) Amygdalonigral pathway: an anterograde study in the rat with Phaseolus vulgaris leucoagglutinin (PHA-L). J. comp. Neurol. 297, 182-200.

32.Groenewegen, H.T., Becker, N.E.H., Lohman, A.H.M. (1980) Subcortical afferents of the nucleus accumbens septi in the cat, studied with retrograde axonal transport of horseradish peroxidase and bisbenzimid. Neuroscience $\mathbf{5}$, 1903.

33. Grove, E.A. (1988a) Neural associations of the substantia innominata in the rat: afferent connections. J. comp. Neurol. 277, 315-346.

34.Grove, E.A., (1988b) Efferent connections of the substantia innominata in the rat. J. comp. Neurol. 277, 347-364.

35.Guarraci, F.A., Frohardt, R.J., Kapp, B.S. (1999) Amygdaloid D1 dopamine receptor involvement in Pavlovian fear conditioning. Brain Res. 827, 28-40. 
36. Heimer, L., Zahm, D.S., Churchill, L., Kalivas, P.W., Wohltmann, C. (1991) Specificity in the projection patterns of accumbal core and shell in the rat. Neuroscience 41, 89-125.

37. Heimer, L., Alheid, G.F., Zahm, D.S., (1993) Basal forebrain organization: an anatomical framework for motor aspects of drive and motivation. In Limbic Motor Circuits and Neuropsychiatry (eds. Kalivas, P.W., Barnes, C.D.), pp. 143. CRC Press, Boca Raton.

38. Heimer, L. (1994) Amygdaloid body and extended amygdala. In: The human brain and spinal cord, $2^{\text {nd }}$ edn., pp. 415-421. Springer-Verlag, New York.

39. Heimer, L., Zahm, D.S., Alheid, G.F. (1995) Basal ganglia. In: The Rat Nervous System, $2^{\text {nd }}$ edn. (ed. Paxinos, G.), pp. 495-578. Academic Press, San Diego.

40.Heimer, L., Harlan, R.E., Alheid, G.F., Garcia, M.M., de Olmos, J. (1997) Substantia innominata: a notion which impedes clinical-anatomical correlations in neuropsychiatric disordes. Neuroscience 76, 957-1006.

41. Herkenham, M., Nauta, W.J.H. (1977) Afferent connections of the habenular nuclei in the rat. A horseradish peroxidase study, with a note on the fiber-ofpassage problem. J. comp. Neurol. 173, 123-145.

42. Hökfelt, T., Martensson, R., Björklund, A, Kleinau, S., Goldstein, S (1984) Distributional maps of tyrosine-hydroxylase-immunoreactive neurons in the rat brain. In Handbook of Chemical Neuroanatomy (eds. Björklund, A., Hökfelt, T.) Vol. 2, Classical transmitters in the CNS, Part I, pp. 277-379, Elsevier, Amsterdan.

43. Itoh, K., Konishi, A., Nomura, S., Mizuno, N.,Nakamura, Y., Sugimoto, T. (1979) Application of coupled oxidation reaction to electron microscopic demonstration of horseradish peroxidase. Brain Res. 175, 341-346. 
44. Kalivas. P.W., Jennes, L., Miller, J.S. (1985) A catecholaminergic projection from VTA to the diagonal band of Broca: modulation by neurotensin. Brain Res. 326, 229-238.

45. Kitahama, K., Mons, N., Okamura, H., Jouvet, M., Geffard, M. (1988) Endogenous L-DOPA, its immunoreactivity in neurons of midbrain and its projection fields in the cat. Neurosci. Lett. 95, 47-52.

46. Klitenick, M.A. Deutch, A.Y., Churchill, L., Kalivas, P.W. (1992) Topography and functional role of dopaminergic projections from the ventral mesencephalic tegmentum to the ventral pallidum. Neuroscience 50, 371-386.

47. Köhler, C., Goldstein, M. (1984) Golgi-like immunoperoxidase staining of dopamine neurons in the reticular formation of the rat brainstem using antibody to tyrosine-hydroxylase. J. comp. Neurol. 223, 302-311.

48. Koob, G.F., Robledo, P., Markou, A., Caine, S.B. (1993) The mesocorticolimbic circuit in drug dependence and reward - a role for the Extended Amygdala? In Limbic Motor Circuits and Neuropsychiatry (eds. Kalivas, P.W., Barnes, C.D.), pp. 289-309. CRC Press, Boca Raton.

49. Koob, G.F. (1999) Drug reward and addiction. In: Fundamental Neuroscience (eds. Zigmond, M.J., Bloom, F.E., Landis, S.C., Roberts, J.L., Squire, L.R.) pp. 1261-1279. Academic Press.

50. Lynd-Balta, E., Haber, S.N. (1994) The organization of midbrain projections to the ventral striatum in the primate. Neuroscience $59,609-623$.

51. Meller, S.T., Dennis, B.J. (1991) Efferent projections of the periaqueductal gray in the rabbit. Neuroscience 40, 191-216.

52. Miachon, S., Berod, A., Leger, L., Chat, M., Hartman, B., Pujol, F. (1984) Identification of catecholamine cell bodies in the pons and ponsmesencephalon junction of the cat brain, using tyrosine hydroxylase and dopamine-ß-hydroxylase immunohistochemistry. Brain Res. 305, 369-374. 
53. Misu, Y., Goshima, Y., Ueda, H., Okamura, H. (1996) Neurobiology of LDOPAergic systems. Progr. Neurobiol. 49, 415-454.

54.Mons, N., Danel, N., Geffard, M. (1988) Visualization of Ldihydroxyphenylalanine in rat brain by using specific antibodies. Brain Res. 451, 403-407.

55. Mons, N., Tison, F., Geffard, M. (1990) Existence of L-DOPA immunoreactive neurons in the rat preoptic area and anterior hypothalamus. Neuroendocrinology 51, 425-428.

56. Morelli, M., Pinna, A., Ruiu, S., Del Zompo, M. (1999) Induction of Fos-likeimmunoreactivity in the central extended amygdala by antidepressant drugs. Synapse 31, 1-4.

57. Moriizumi, T. and Leduc-Cross, B. (1992) Is there a dopaminergic projection from the A11 catecholamine cell group to the amygdala? Exp. Brain Res. 88, 451-454.

58. Moriizumi, T., Leduc-Cross, B., Wu, J.-Y., Hattori, T. (1992) Separate neuronal populations of the rat substantia nigra pars lateralis with distinct projection sites and transmitter phenotypes. Neuroscience 43, 711-720.

59. Nauta, W.J.H., Smith, G.P., Faull, R.L.M., Domesick, V.B. (1978) Efferent connections and nigral afferents of the nucleus accumbens septi in the rat. Neuroscience 3, 385-401.

60. Nemoto, C., Hida, T., Arai, R. (1999) Calretinin and calbindin-D28k in dopaminergic neurons of the rat midbrain: a triple labeling immunohistochemical study. Brain Res. 846, 129-136.

61. Newman, R., Winans, S.S. (1980) An experimental study of the ventral striatum of the golden hamster. I. Neural connections of the nucleus accumbens. J. comp. Neurol. 191, 167-192. 
62. Nishihama, M., Miyamae, T., Goshima, Y., Okumura, F., Misu, Y. (1999) An Ldopaergic relay from posterior hypothalamic nucleus to the rostral ventrolateral medulla and its cardiovascular function in anesthetized rats. Neuroscience 92, 123-35.

63. Oades, R.D., Halliday, G.M. (1987) Ventral tegmental (A10) system: neurobiology. 1. Anatomy and connectivity. Brain Res. Rev. 12, 117-165.

64. Okamura, H., Kitahama, K., Mons, N., Ibata, Y., Jouvet, M., Geffard, M. (1988) L-DOPA-immunoreactive neurons in the rat hypothalamic tuberal region. Neurosci. Lett. 95, 42-46.

65. Paxinos, G., Watson, C. (1986) The Rat Brain in Stereotaxic Coordinates. $2^{\text {nd }}$ edn. Academic Press, San Diego.

66. Paxinos, G., Watson, C. (1997) The Rat Brain in Stereotaxic Coordinates. $3^{\text {nd }}$ edn. Academic Press, San Diego.

67.Peyron, C., Petit, J.M., Rampon, C., Jouvet, M., Luppi, P.H. (1998) Forebrain afferents to the rat dorsal raphe nucleus demonstrated by retrograde and anterograde tracing methods. Neuroscience 82, 443-468.

68. Phillipson, O.T. (1979) Afferent projections to the ventral tegmental area of Tsai and interfascicular nucleus: a horseradish peroxidase study in the rat. $J$. comp. Neurol. 187, 117-144.

69. Phillipson, O.T., Griffiths, A.C. (1985) The topographic order of inputs to nucleus accumbens in the rat. Neuroscience 16, 275-296.

70.Price, J.L., Amaral, D.G. (1981) An autoradiographic study of the projections of the central nucleus of the monkey amygdala. J. Neurosci. 1, 1242-1259.

71.Price, J.L., Russchen, F.T., Amaral, D.G. (1987) The limbic region. II. The amygdaloid complex. In: Handbook of Chemical Neuroanatomy (eds. Björklund, A., Hökfelt, T., Swanson, L.W.). Vol 5, Integrated systems of the CNS, Part 1, pp. 279-388. Elsevier, Amsterdam. 
72. Rizvi, T.A. Ennis, M., Behbehani, M.M., Shipley, M.T. (1991) Connections between the central nucleus of the amygdala and midbrain periaqueductal gray: topography and reciprocity. J. comp. Neurol. 303, 121-131.

73.Seroogy, K.B., Dangaran, K., Lim, S., Haycock, J.W., Fallon, J.H. (1989) Ventral mesencephalic neurons containing both colecystokinin- and tyrosinehydroxylase-like immunoreactivities project to forebrain regions. $J$. comp. Neurol. 279, 397-414.

74.Shammah-Lagnado, S.J., Alheid, G.F., Heimer, L. (1996) Efferent connections of the caudal part of the globus pallidus in the rat. J. comp. Neurol. 376, 489507.

75. Shammah-Lagnado, S.J., Alheid, G.F., Heimer, L. (1999) Afferent connections of the interstitial nucleus of the posterior limb of the anterior commissure and adjacent amygdalostriatal transition area in the rat. Neuroscience 94, 10971123.

76. Shammah-Lagnado, S.J., Beltramino, C.A., McDonald, A.J., Miselis, R.R., Yang, M., de Olmos, J., Heimer, L., Alheid, G.F. (2000) Supracapsular bed nucleus of the stria terminalis contains central and medial extended amygdala elements: evidence from anterograde and retrograde tracing experiments in the rat. J. comp. Neurol. 422, 533-555.

77. Spanagel, R., Weiss, F. (1999) The dopamine hypothesis of reward: past and current status. Trends Neurosci. 22, 521-527.

78. Stratford, T.R., Wirtshafter, D. (1990) Ascending dopaminergic projections from the dorsal raphe nucleus in the rat. Brain Res. 511, 173-176.

79.Swanson, L.W., (1982) The projections of the ventral tegmental area and adjacent regions: a combined fluorescent retrograde tracer and immunofluorescence study in the rat. Brain Res. Bull. 9, 321-353.

80.Takada, M. (1993) Widespread dopaminergic projections of the subparafascicular thalamic nucleus in the rat. Brain Res. Bull. 32, 301-309. 
81. Tan, Y., Brog, J.S., Williams, E.S., Zahm, D.S. (1995) Morphometric analysis of ventral mesencephalic neurons retrogradely labeled with Fluoro-Gold following injections in the sell, core and rostral pole of the rat nucleus accumbens. Brain Res. 689, 151-156.

82.Tan, Y., Williams, E.S., Zahm, D.S. (1999) Calbindin-D 28kD immunofluorescence in ventral mesencephalic neurons following injections of Fluoro-Gold in the nucleus accumbens. Brain Res. 844, 67-77.

83. Tison, F., Mons, M., Rouet-Karama, S., Geffard, M., Henry, P. (1989) Endogenous L-DOPA in the rat dorsal vagal complex: an immunocytochemical study by light and electron microscopy. Brain Res. 497, 260-270.

84. Tison, F., Mons, N., Geffard, M., Henry, P. (1990) Immunohistochemistry of endogenenous L-DOPA in the rat posterior hypothalamus. Histochemistry 93, 655-660.

85. Ungerstedt, U. (1971) Stereotaxic mapping of the monoamine pathways in the rat brain. Acta physiol. Scand. (suppl) 367, 1-48.

86. Vertes, R.P. (1991) A PHA-L Analysis of ascending projections of the dorsal raphe nucleus in the rat. J. comp. Neurol. 313, 643-668.

87.Voorn, P., Jorritsma-Byham, B., Van Dijk, C., Buijs, R.M. (1986) The dopaminergic innervation of the ventral striatum in the rat: a light- and electron-microscopical study with antibodies against dopamine. J. comp. Neurol. 251, 84-99.

88.Wagner, C.K., Eaton, M.J., Moore, K.E., Lookingland, K.J. (1995) Efferent projections from the region of the medial zona incerta containing A13 dopaminergic neurons: a PHA-L anterograde tract-tracing study in the rat. Brain Res. 677, 229-237.

89. Wallace, D. M., Magnuson, D.J., Gray, T.S. (1992) Organization of amygdaloid projections to brainstem dopaminergic, noradrenergic, and adrenergic cell groups in the rat. Brain Res. Bull. 28, 447-454. 
90. Weiner, D.M., Levey, A.I., Sunahara, R.K., Niznik, H.B., O'Dowd, B.F., Seeman, P., Brann, M.R. (1991) D1 and D2 dopamine receptor in mRNA in rat brain. Proc. Natl. Acad. Sci. 88, 1859-1863.

91. Weller, K.L., Smith, D.A. (1982) Afferent connections to the bed nucleus of the stria terminalis. Brain Res. 232, 255-270.

92. Wu, Y.L., Yoshida, M., Emoto, H., Tanaka, M. (1999) Psychological stress selectively increases extracellular dopamine in the "shell" but not in the "core" of the rat nucleus accumbens: a novel dual-needle probe simultaneous microdialysis study. Neurosci. Lett. 275, 69-72.

93.Young, A.M.J., Rees, K.R. (1998) Dopamine relaese in the amygdaloid complex of the rat, studied by brain microdialysis. Neurosci. Lett. 249, 49-52.

94.Zahm, D.S., Brog, J.S., (1992) On the significance of subterritories in the "accumbens" part of the rat ventral striatum. Neuroscience 50, 751-767.

95.Zahm, D.S. (1998) Is the caudomedial shell of the nucleus accumbens part of the extended amygdala? A consideration of connections. Crit. Rev. Neurobiol. 12, 245-265.

96.Zahm, D.S., Jensen, S.L., Williams, E.S., Martin III, J.R. (1999) Direct comparison of projections from the central amygdaloid region and nucleus accumbens shell. Eur. J. Neurosci. 11, 1119-1126.

97.Zardetto-Smith, A.M., Beltz, T.G., Johnson, A.K. (1994) Role of the central nucleus of the amygdala and bed nucleus of the stria terminalis in experimentally-induced salt appetite. Brain Res. 645, 123-134. 